\title{
Resolvins, Protectins, and Maresins: DHA-Derived Specialized Pro-Resolving Mediators, Biosynthetic Pathways, Synthetic Approaches, and Their Role in Inflammation
}

\author{
Inês Ferreira $^{1,2}$, Filipa Falcato ${ }^{2}$, Narcisa Bandarra ${ }^{2,3, *}$ and Amélia P. Rauter 1,*D \\ 1 Centro de Química Estrutural, Institute of Molecular Sciences, Faculdade de Ciências, \\ Universidade de Lisboa, Ed. C8, Piso 5, Campo Grande, 1749-016 Lisboa, Portugal; fc53396@alunos.fc.ul.pt \\ 2 Division of Aquaculture, Upgrading and Bioprospecting, Portuguese Institute of the Sea and Atmosphere, \\ Rua Alfredo Magalhães Ramalho, 6, 1495-006 Lisboa, Portugal; f.falcato@campus.fct.unl.pt \\ 3 Interdisciplinary Centre of Marine and Environmental Research (CIIMAR), University of Porto, \\ Rua dos Bragas 289, 4050-123 Porto, Portugal \\ * $\quad$ Correspondence: narcisa@ipma.pt (N.B.); aprauter@fc.ul.pt (A.P.R.); Tel.: +351-964408824 (A.P.R.)
}

Citation: Ferreira, I.; Falcato, F.; Bandarra, N.; Rauter, A.P. Resolvins, Protectins, and Maresins: DHA-Derived Specialized Pro-Resolving Mediators, Biosynthetic Pathways, Synthetic Approaches, and Their Role in Inflammation. Molecules 2022, 27, 1677. https://doi.org/10.3390/ molecules27051677

Academic Editor: Gianfranco Romanazzi

Received: 1 January 2022

Accepted: 16 February 2022

Published: 3 March 2022

Publisher's Note: MDPI stays neutral with regard to jurisdictional claims in published maps and institutional affiliations.

Copyright: () 2022 by the authors. Licensee MDPI, Basel, Switzerland. This article is an open access article distributed under the terms and conditions of the Creative Commons Attribution (CC BY) license (https:// creativecommons.org/licenses/by/ $4.0 /)$.

\begin{abstract}
Marine organisms are an important source of natural products with unique and diverse chemical structures that may hold the key for the development of novel drugs. Docosahexaenoic acid (DHA) is an omega-3 fatty acid marine natural product playing a crucial regulatory role in the resolution of inflammation and acting as a precursor for the biosynthesis of the anti-inflammatory specialized pro-resolving mediators (SPMs) resolvins, protectins, and maresins. These metabolites exert many beneficial actions including neuroprotection, anti-hypertension, or anti-tumorigenesis. As dysregulation of SPMs is associated with diseases of prolonged inflammation, the disclosure of their bioactivities may be correlated with anti-inflammatory and pro-resolving capabilities, offering new targets for drug design. The availability of these SPMs from natural resources is very low, but the evaluation of their pharmacological properties requires their access in larger amounts, as achieved by synthetic routes. In this report, the first review of the total organic syntheses carried out for resolvins, protectins, and maresins is presented. Recently, it was proposed that DHA-derived pro-resolving mediators play a key role in the treatment of COVID-19. In this work we also review the current evidence on the structures, biosynthesis, and functional and new-found roles of these novel lipid mediators of disease resolution.
\end{abstract}

Keywords: marine sources; DHA; SPMs; resolvins; protectins; maresins; synthetic approaches; anti-inflammatory activity

\section{Introduction}

The oceans cover more than two-thirds of the earth's surface, and it is estimated that the marine environment hosts most of the organisms living on earth. The number of marine species that inhabit the oceans is not known yet, although it is estimated that marine species include about 1-2 million of total earth species. Due to its phenomenal biodiversity, the marine world is the most valuable natural resource, and it is a very challenging, competitive, and aggressive environment that demands organisms' adaptation to this unique habitat and the subsequent production of quite specific and potent biologically active compounds $[1,2]$.

In the last decade, the marine environment has attracted the attention of researchers; however, oceans, as a source of novel marine drugs, remain quite unexplored. It is estimated that more than 10,000 marine natural products (MNPs), with therapeutic potential for healthcare, have been extracted and isolated from bacteria, sponges, algae, bryozoans, cnidarians, tunicates, molluscs, fungi, and other marine organisms. These compounds, mostly primary and secondary metabolites, demonstrated a unique and diverse chemical structure that may hold the key for the development of novel drug hits and leads. These 
compounds demonstrated significant biological activities including anticancer, anticoagulant, antiviral, antibacterial, antidiabetic, antihypertensive, antioxidant, anti-inflammatory, antimalarial, and antituberculosis properties [3]. Geographical locations can define different secondary metabolites and their concentration due to environmental factors such as salinity, temperature, pollution levels, light intensity, and predation balance [4,5]. Among the compounds that demonstrated significant biological activities are peptides isolated from fish, algal polysaccharides, carotenoids and phenolic compounds from shellfish and seaweeds, and omega-3 fatty acids from fish oil [6].

Omega-3 fatty acids are polyunsaturated fatty acids (PUFA) and have a vast nutraceutical potential with beneficial effects against a diversity of diseases (Table 1).

Table 1. Nutraceutical potential of omega-3 fatty acids.

\begin{tabular}{cc}
\hline Health Benefits of Dietary Supplementation & Reference \\
\hline Reduce risks of macular degeneration and cancers & {$[7]$} \\
Protect against atherosclerotic heart disease and sudden coronary death & {$[8]$} \\
Have beneficial effect in patients with Meibomian gland dysfunction (MGD) & {$[9]$} \\
Reduce risks of developing cardiovascular disease (CVD), coronary heart disease & {$[10]$} \\
(CHD), and myocardial infarction (MI) & {$[11]$} \\
Reduce risks of Parkinson's and Alzheimer's disease & {$[12]$} \\
Decrease systolic and diastolic blood pressure & {$[13]$} \\
Inhibit pro-inflammatory signalling cascades &
\end{tabular}

Amongst omega-3 PUFA, docosahexaenoic acid (DHA, 22:6n-3) is particularly important, and despite the availability of desaturase and elongase enzymes required for the biosynthesis of DHA (Scheme 1), its synthesis is minimal in humans [14], and DHA must be obtained from dietary sources, particularly from seafood such as mackerel, salmon, herring, tuna, sardines, and products derived from seafood [15,16] or seaweeds [17].

\section{Alpha-linolenic acid (ALA)}

\section{$\checkmark \Delta^{6}$-desaturase}

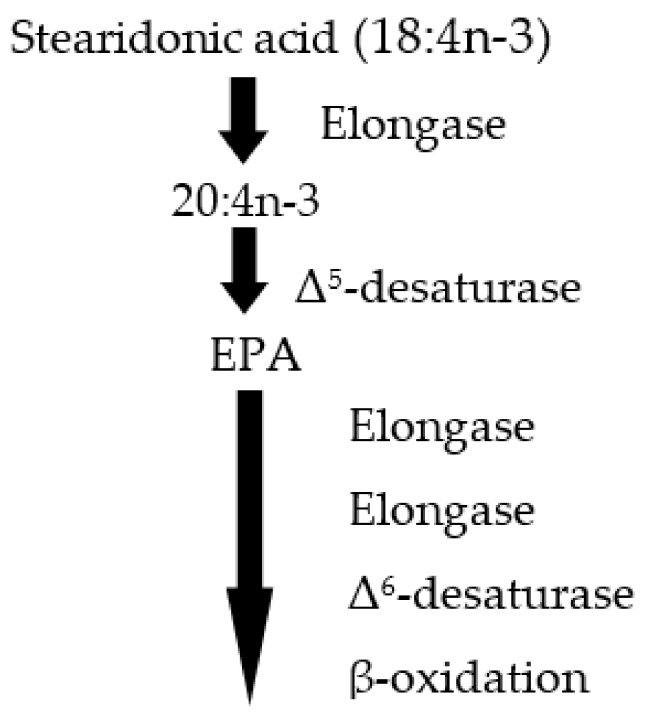

DHA (22:6n-3)

Scheme 1. Pathway of alpha-linolenic and conversion to DHA. 
Omega-3 fatty acids, including DHA, are mainly found esterified with glycerol as triacylglycerols (TAG), as components of phospholipid structure (PL), as cholesterol esters (CE), and as free fatty acids (FFA) [18].

DHA has a long and highly unsaturated chain with 22 carbons and 6 double bonds (Figure 1).

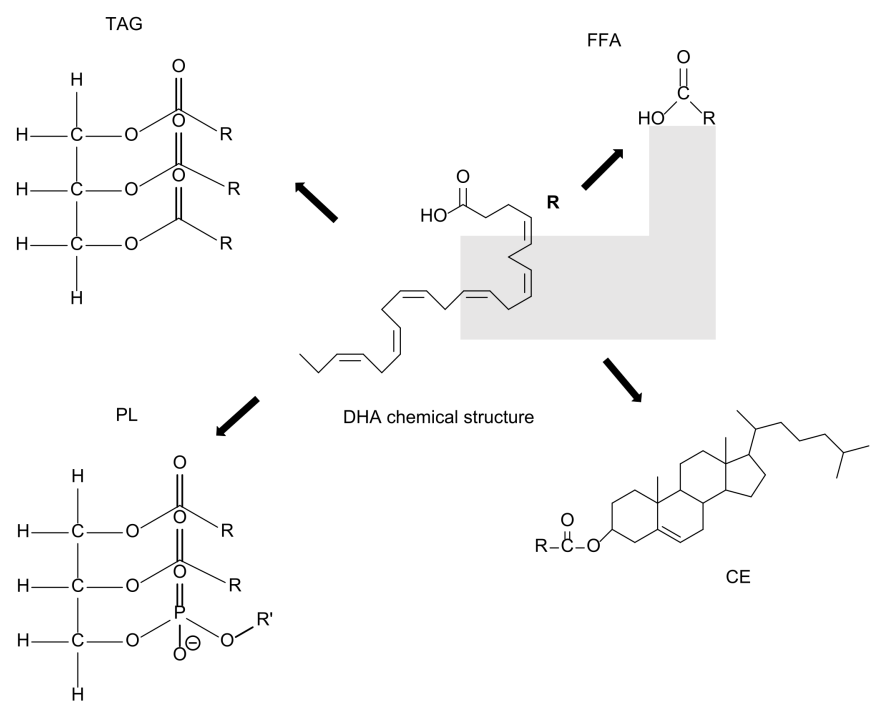

Figure 1. DHA chemical structure and DHA esters found in marine organisms: TAG, triacylglycerols; PL, phospholipid with $\mathrm{R}^{\prime}$ = serine, choline, and ethanolamine; FFA, free fatty acid; CE, cholesterol ester.

DHA is essential for the growth, maintenance, and development of normal brain and visual function. It is a structural constituent of cell membranes and has a significant influence on cellular behaviour, fluidity, permeability, anti-inflammatory processes, and neuronal signalling [19]. Several studies also indicate that n-3 PUFA are essential for proper foetal development, where DHA plays a crucial role for optimal vision, cognitive development, and behaviour $[20,21]$. In order to prevent deficiencies associated with a low DHA intake, the WHO recommended a daily intake of DHA + EPA (eicosapentaenoic acids) at $250 \mathrm{mg}$ for adult [22].

Based on a work developed by Cardoso et al. [14,18], the highest content of DHA can be found in chub mackerel (2128 mg/100 g), Atlantic salmon (1773 mg/100 g), or European eel (3447 mg/100 g). Additionally, microalgae Thraustochytrium aureum ATCC 34,304 are rich in DHA (6590 mg/100 g of dry matter) [14].

\section{From DHA to SPMs and Their Functional Role}

DHA is a substrate for cyclooxygenases (COXs) and lipoxygenases (LOXs), being enzymatically oxidized to mono-, di-, and tri-hydroxyDHA (HDHAs), oxidized to epoxides, oxidized to oxo-DHA metabolites, or oxidized to neuroprostanes, among other compound families. HDHAs include the specialized pro-resolving mediators (SPMs) or docosanoids, comprising D-series resolvins (RvD), protectins (PD), and maresins (MaRs) (Figure 2), which are available at sites of acute inflammation, acting in a specific tissue [23], and potent lipid mediators, with benefits of the prevention and treatment of several diseases. HDHAs have shown benefits of neuroprotection, benefits against the risks of cardiovascular diseases, and anti-tumour properties, among others [24]. 


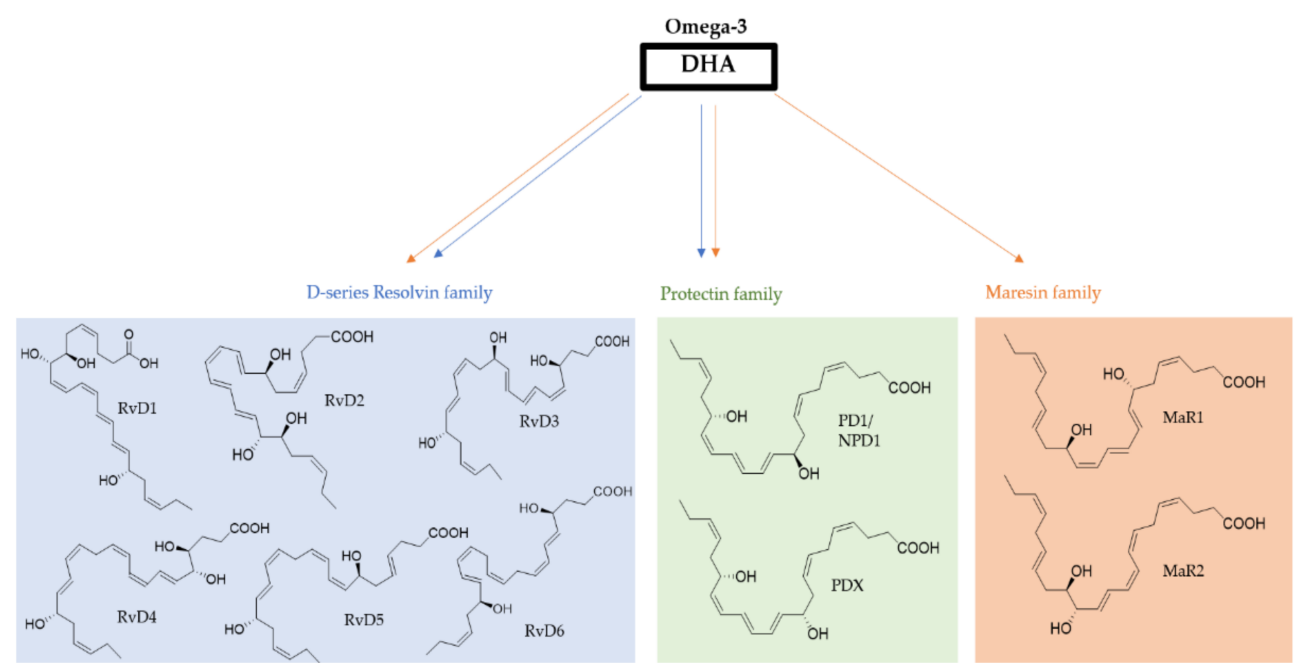

Figure 2. Structure of the SPMs D-series resolvins, protectins, and maresins, which are metabolites derived from DHA.

Four types of SPMs have been classified depending on the precursor molecule that they derive from and the enzyme implicated in metabolic cascade: lipoxins (LXs), RvD and RvE, PD, and MaRs. Lipoxins (LXs) result from a biosynthetic pathway of omega- 6 fatty acid: araquidonic acid. LXs were the first SPM to be described and studied due to their essential role in various inflammatory diseases [25]. Resolvins from EPA (E-resolvins) and from DHA (D-resolvins) and protectins and maresins from DHA are structurally distinct from LXs resulting from a different metabolic pathway from omega-3 fatty acids.

SPMs are active in subnanomolar doses in between the picogram and nanogram levels, promoting stereospecific activation of cellular receptors on diverse cells of immune system and organ-specific protectors. SPMs have special functions and direct action on inflammation control and resolution phase. They can act on immune cells such as neutrophils and macrophages, endothelial and epithelial cells, and lymphocytes [26,27].

Given the influence of uncontrolled inflammation to diverse human pathologies, the identification of endogenous control mechanisms in acute inflammatory response has become essential. Inflammation reaction is an essential protective mechanism for preserving health and normally is well-organized and controlled, leading to a quick response and normal tissue structure repair. However, if the wound healing response is dysregulated, it can be characterized by a weak inflammatory response that can lead to tissue destruction by harmful stimuli or chronic unresolved inflammation. This event may culminate in diverse pathologies such as arthritis, cardiovascular disease, neurodegenerative diseases such as Alzheimer's and Parkinson's, asthma, cancer, and autoimmune diseases [27,28]. Following microbial infection or tissue injury, the release of pro-inflammatory lipid mediators is among the first signalling events, promoting the recruitment of neutrophils (polymorphonuclear leukocytes (PMN)) [29]. Although the acute inflammatory response is protective, when an excess of PMN congregates or swarms in tissues, it can lead to tissue damage that ultimately amplifies inflammation, causing a wide range of acute, chronic, and systemic inflammatory disorders $[27,29-31]$. Thus, it becomes crucial to understand the underlying mechanisms and specialized mediators involved in the resolution process.

Known as immunoresolvents and recognized by their potent stereoselective, proresolving, and anti-inflammatory actions, SPMs can stimulate the resolution of inflammation without immune suppression [27,32-34]. Each family of SPM will promote the recruitment and activation of monocytes and will block neutrophil recruitment, which will lead to both the resolution of inflammation and homeostasis through the combined actions of these mediators [29]. SPMs are enzymatically produced in human body fluids and organs, being involved mainly in the resolution of inflammation, wound healing, and neuroprotection. The use of SPMs can reduce the treatment with antibiotics against 
infection and is a new approach to the development of alternative and effective therapies for several diseases [24,35]. The identification of resolvins, protectins, and maresins is of great importance, as these potent lipid mediators provide the first molecular basis for many of the health benefits attributed to DHA. However, for many of them, the specific molecular mechanisms remain unclear [29,36-38]. Thus, disclosure of the biosynthetic pathways for conversion of DHA to SPMs, along with their structural elucidation and bioactivities evaluation, is crucial to the understanding of inflammation resolution. By promoting the resolution of inflammation, clearance of microbes, reduction in pain, and promotion of tissue regeneration via specific cellular and molecular mechanisms, they have gained the attention of the scientific community [39]. The anti-inflammatory and pro-resolution functions of SPMs are attained by binding to specialized G-protein-coupled receptors (GPCRs). Between these GPCRs are GPR32, FPR2/ALX, GPR18 for resolvins, ROR $\alpha$ and ALX/FPR2 for maresins, and GPR84 and GPR120 for protectins [35,40,41].

Some of the molecular and cellular effects of DHA-derived SPMs are summarized in Table 2. Within the resolvins family, RvD1, RvD2, RvD3, RvD4, RvD5, and RvD6 were identified as well as the series of lipid mediators' aspirin-triggered forms (AT-RvD), differing in their stereochemistry (Schemes 2 and 3), as well as protectins PD1 and MaR1 and MaR2.

Table 2. DHA-derived SPM actions in disease models and cell targets.

\begin{tabular}{|c|c|c|c|}
\hline SPM & Target & Bioaction & Reference \\
\hline \multirow[t]{5}{*}{ RvD1 } & $\begin{array}{l}\text { Polymorphonuclear } \\
\text { leukocyte }\end{array}$ & Decreases infiltration in murine skin air pouch model; limits infiltration & {$[36,42,43]$} \\
\hline & Microglial cells & Inhibits IL- $1 \beta$ expression in vitro & [36] \\
\hline & $\begin{array}{l}\text { Vascular inflammation } \\
\text { (arterial angioplasty) }\end{array}$ & $\begin{array}{c}\text { Attenuates cell proliferation, leukocyte recruitment, and neointimal } \\
\text { hyperplasia }\end{array}$ & {$[44]$} \\
\hline & Alzheimer's disease & Stimulates phagocytosis of $A \beta$ by Alzheimer's disease macrophages & [45] \\
\hline & Pain & Controls inflammatory pain & [46] \\
\hline \multirow[t]{5}{*}{ AT-RvD1 } & Pain ... & Controls inflammatory pain & {$[47]$} \\
\hline & $\begin{array}{l}\text { Temporomandibular joint } \\
\text { inflammation }\end{array}$ & Limits PMN infiltration to CFA-inflamed TMJ & [48] \\
\hline & Arthritis & Antihyperalgesic & [49] \\
\hline & Fibromyalgia & $\begin{array}{c}\text { Reduces mechanical allodynia and thermal sensitization and prevents } \\
\text { depressive behaviour }\end{array}$ & {$[50]$} \\
\hline & $\begin{array}{l}\text { Postsurgical cognitive } \\
\text { decline }\end{array}$ & Improves postoperative decline and attenuates memory & [51] \\
\hline \multirow[t]{6}{*}{ PD1 } & $\begin{array}{l}\text { Polymorphonuclear } \\
\text { leukocvte }\end{array}$ & Upregulates CCR5 expression; reduces tissue infiltration & {$[52,53]$} \\
\hline & Macrophages & Stimulates phagocytosis of apoptotic polymorphonuclear leukocyte & [54] \\
\hline & T Cell & Promotes apoptosis in vitro & [55] \\
\hline & Glial cells & Reduces cytokine production & [56] \\
\hline & Epithelial cells & $\begin{array}{r}\text { Protects from oxidative stress-induced apoptosis (retinal pigment } \\
\text { epithelium) }\end{array}$ & {$[38]$} \\
\hline & Eosinophils & Decreases recruitment in response to allergen & [57] \\
\hline \multirow[t]{2}{*}{ RvD2 } & Macroglia & $\begin{array}{c}\text { Prohibits or reduces the activation of macroglia and microglia, } \\
\text { respectively }\end{array}$ & {$[58]$} \\
\hline & Burn wound & $\begin{array}{l}\text { Downregulates TNF- } \alpha \text {, IL- } 1 \beta \text {, iNOS, NF-k, NO, and ROS production } \\
\text { Prevents secondary thrombosis and necrosis }\end{array}$ & {$[35]$} \\
\hline $\begin{array}{l}\text { RvD3 and } \\
\text { AT-RvD3 }\end{array}$ & Neutrophils & $\begin{array}{c}\text { Regulates neutrophils and mediators, reducing murine peritonitis and } \\
\text { dermal inflammation }\end{array}$ & [59] \\
\hline RvD4 & $\begin{array}{l}\text { Protection and resolution of } \\
\text { inflammation during } \\
\text { bacterial infection }\end{array}$ & $\begin{array}{l}\text { Stops leukocyte influx to the site of infection in the dorsal pouch cavity } \\
\text { as well as the inflammation-initiating eicosanoids by reducing levels of } \\
\qquad \mathrm{PGD}_{2} \text { and } \mathrm{LTB}_{4}\end{array}$ & {$[60]$} \\
\hline RvD5 & Bacterial infection & $\begin{array}{l}\text { Increases survival and lower antibiotic requirement } \\
\text { Decreases inflammation and increases }\end{array}$ & [48] \\
\hline RvD6 & Corneal nerve & $\begin{array}{l}\text { regeneration by decreasing the expression of the ACE2 receptor, furin, } \\
\text { and integrins. }\end{array}$ & [61] \\
\hline \multirow[t]{3}{*}{ MaR1 } & Pain & Controls inflammatory pain & [37] \\
\hline & Tissue regeneration & $\begin{array}{l}\text { Promotes tissue regeneration in planaria } \\
\text { Treats amyotrophic lateral sclerosis and spinal muscular atrophy }\end{array}$ & [37] \\
\hline & Neuroprotection & Accelerates clearance of neutrophils and a reduction in macrophage & {$[62,63]$} \\
\hline MaR2 & Macrophage phagocytosis & Anti-inflammatory activity & [64] \\
\hline
\end{tabular}




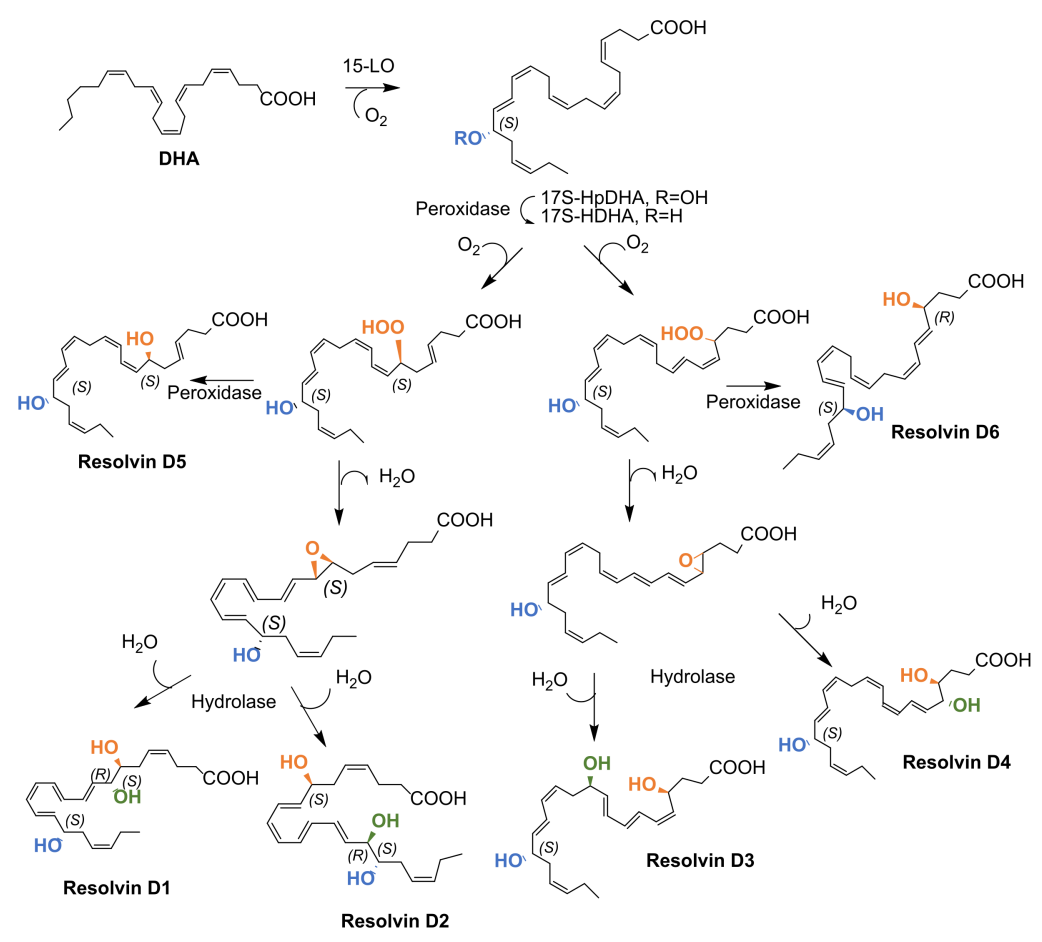

Scheme 2. D-series resolvins biosynthesis by LOX mechanism.

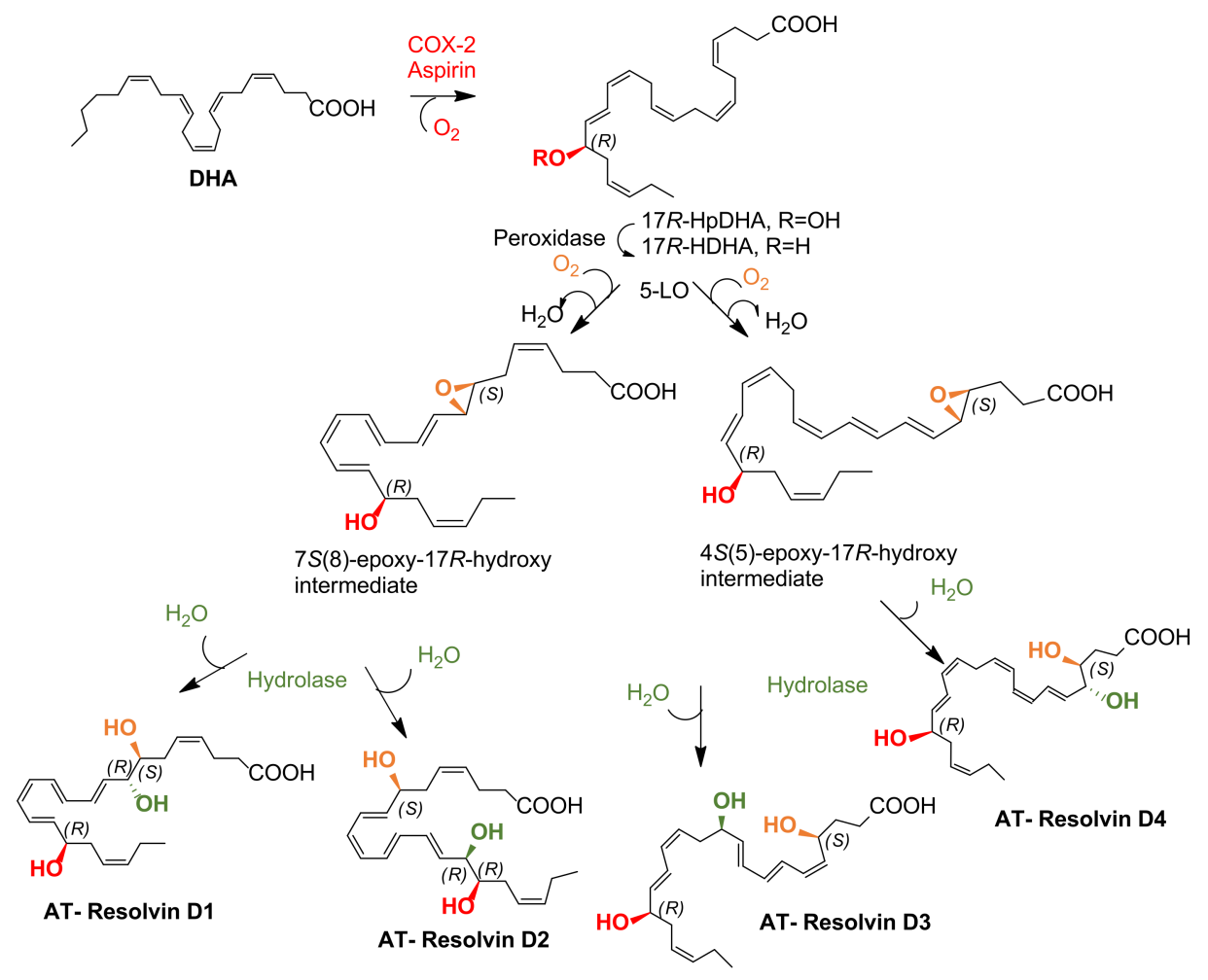

Scheme 3. D-series resolvins biosynthesis by aspirin-triggered COX-2.

In the next sections, the biosynthesis and the total organic synthesis of these proresolving mediators are presented and discussed.

\section{Resolvins from DHA}

Pro-resolving oxylipins biosynthesized from DHA, commonly known as Rvs, are primarily anti-inflammatory in nature [65]. Resolvins have strong ability to respond for reg- 
ulation of pro-inflammation and actively stimulate resolution via monocyte/macrophage uptake of debris, apoptotic PMN, and by clearing microbes [36,66,67]. Chunrong and coworkers [35] revealed that these metabolites can have even more potent anti-inflammatory and pro-resolving activities than their precursors. The Rvs derived from DHA are Rvs of D-series and were reported as neuroprotective agents, exerting their protective effect against cell injury-induced oxidative stress $[38,68,69]$. The six identified resolvins and the aspirin-triggered forms are biosynthesized by aspirin-triggered cyclooxygenase-2 $[24,26,35]$ (see Section 3.1). Due to the stereospecific activation of cellular receptors, each SPM carries defined biological functions with cell type- and organ-specific properties [70]. Recently, the beneficial roles of resolvins against diabetes and kidney disease were revised [71]. In various experimental kidney disease models, RvD1 was found to restore kidney tubule function, inhibit NF- $\mathrm{\kappa B}$ and IL-6 activation [72], increase regulatory T cells, and attenuate tubular injury [73] and to attenuate fibrosis, fibroblast proliferation, and collagen deposition in an experimental model of unilateral ureteral obstruction [74]. Resolvins also suppress tumour growth and enhance cancer therapy [75].

\subsection{Biosynthesis of D-Series and Aspirin-Dependent D-Series Resolvins}

D-Series Rvs biosynthesis occurs in mononuclear cells, such as macrophages and neutrophils, endothelial cells, fibroblasts, and monocytes (under inflammatory conditions), and in vascular cells and tissues [35,76]. There are two pathways to biosynthesize RvDs: by the lipoxygenase (LOX) mechanism (Scheme 2) or through the aspirin-triggered cyclooxygenase-2 (COX-2) pathway (Scheme 3) [27,29,35].

The biosynthetic conversion of DHA to D-series Rv (RvD1-RvD6) is illustrated in Scheme 3. The initial step proceeds via lipoxygenation of DHA at carbon 17 catalysed by 15-lipoxygenase (15-LO) to give (17S,4Z,7Z,10Z,13Z,15E,19Z)-17-hydroperoxydocosahexaenoic acid (abbreviated as 17S-HpDHA), which is transformed into the corresponding 17S-hydroxyDHA (17S-HDHA) by a peroxidase. A second lipoxygenation by 5-LO at carbon 7 is followed by catalysis with a peroxidase to give RvD5. Dehydration affords an intermediate epoxide, which when hydrolysis-catalysed by a hydrolase gives RvD1 and RvD2. Lipoxygenation at carbon 4 catalysed by 5-LO gives a hydroperoxide, which generates RvD6 under peroxidase catalysis or is dehydrated to form a 4,5-epoxide, which in turn, under hydrolase catalysis, gives RvD3 and RvD4. The steps covering 5-lipoxygenation and epoxide formation can occur within a single cell type or via transcellular biosynthesis [29].

Alternatively, RvDs biosynthesis can be initiated by the aspirin-dependent acetylated COX-2 enzyme to give the 17R-series RvDs. In fact, acetylated COX-2 in the presence of aspirin acts as a modified dioxygenase by introducing an oxygen molecule with opposite stereochemistry [29]. The RvDs biosynthesized through aspirin and acetylated COX-2 also undergo lipid oxidation catalysed by 15-LO and 5-LO, epoxidation, and hydrolysis processes, forming AT-RvDs (Scheme 3).

The biosynthetic pathway of AT-RvDs could partly explain some anti-inflammatory effects of aspirin since COX-2 in its presence biosynthesizes metabolically more stable SPM epimers, with pro-resolving and anti-inflammatory activities $[29,77]$. As shown in Schemes 2 and 3, RvDs and AT-RvDs differ in their $R / S$ configuration of each OH group containing chirality centre. AT-RvDs are equally potent anti-inflammatory agents, but the " $R$ " isomers have longer biological half-lives and have a higher resistance to the metabolic inactivation by oxidoreductases $[59,78]$.

\subsection{Total Synthesis of D-Series Resolvins}

The availability of resolvins from natural resources is low, but they can be generated in vitro via one-pot single enzyme incubation [43,79], although in vivo RvD1 requires two lipooxygenation steps. However, for the evaluation of their biological and pharmacological properties, it is of great importance to have an easy access to these compounds, which has challenged scientists to develop synthetic routes towards resolvins. 


\subsubsection{Resolvin D1}

The first total synthesis of RvD1 was carried out by Serhan et al., via a Sonogashira reaction, whose studies also covered RvD1 natural product structure assignment [29,79]. In 2012, Rodríguez and Spur [80], inspired by Serhan et al. reports [29,79], reported an elegant and successful approach, also based on the Sonogashira reaction, by reacting the alkyne component containing part $A$ and the iodide containing part B, as depicted in Scheme 4 [80]. The starting material was 2-deoxy-3,4-O-isopropylidene-d-erythro-pentopyranose (1), used twice to install a double bond through Wittig olefination (Scheme $4 \mathrm{~A}, \mathrm{~B}$ ). The synthesis of the cis-isomer 2 was achieved in $43 \%$ yield by reaction of 1 with the phosphorane resulting from the treatment with base of [(ethoxycarbonyl)propyl] triphenylphosphonium bromide. Dess-Martin periodinane oxidation of the primary alcohol gave the aldehyde, which was again submitted to another Wittig reaction with the appropriate phosphorane, followed by cis-trans isomerism with iodine/benzene to afford the trans-trans diene isomer 4 in $80 \%$ yield. Cleavage of the trimethylsilyl group with potassium fluoride afforded the triple bond required for the Sonogashira reaction, in which precursor 5 reacts with the iodoester 8, installing RvD1 parent structure, as depicted in Scheme 4. The synthesis of 8 was carried out by Wittig reaction of $\mathbf{1}$ with propylenetriphenylphosphorane, followed by treatment with butyl lithium and acid work-up, providing 8 in 19.7\% overall yield from 1 (Scheme 4A). The Sonogashira reaction gave compound $\mathbf{9}$ in high yield, which was submitted to isopropylidene cleavage in acid medium generated by $\mathrm{CH}_{3} \mathrm{COCl}$ in methanol. After reduction of the triple bond with $\mathrm{Zn}(\mathrm{Cu} / \mathrm{Ag})$ and hydrolysis of the ester with lithium hydroxide, the RvD1 was obtained in 56.7\% yield from precursor 9 (yield over the last three steps).

Recently, in 2019, Kobayashi et al. [81] reported the synthesis of RvD1 also using a Sonogashira reaction but changing the reaction partners. In this approach, the iodoester 10 reacted with the alcohol with the terminal triple bond to afford RvD1 after reduction with Zinc, deprotection with tert-butyl ammonium fluoride, and ester hydrolysis, in overall yield of $72.5 \%$.

The preparation of the iodoester $\mathbf{1 0}$ was accomplished in fifteen steps in an overall yield of $2.3 \%$ starting from butyrolactone. After the first seven steps to obtain the epoxide 12 [81], Swern oxidation of the primary alcohol was followed by treatment with base to generate epoxide ring opening and elimination, giving the unsaturated aldehyde 13 , the hydroxy group of which was then protected with the tert-butyldimethylsilyl (TBS) group. Then, reaction with TMSC $(\mathrm{Li}) \mathrm{N}_{2}[82,83]$ afforded the trans-enyne 15 in very good yield. Hydrozirconation with $\mathrm{Cp}_{2} \mathrm{Zr}(\mathrm{H}) \mathrm{Cl}$, obtained in situ from $\mathrm{Cp}_{2} \mathrm{ZrCl}_{2}$ and diisobutylaluminium hydride (DIBAL) [84], followed by iodinolysis of the zirconium species formed, gave $\mathbf{1 6}$ in reasonable yield (75\%). Removal of silyl groups with tert-butylammonium fluoride (TBAF) and resilylation to have all free hydroxy groups protected with the TBS group was followed by regioselective deprotection with piridinium $p$-toluenesulfonate (PPTS) to afford the free primary hydroxy group. Swern oxidation gave the aldehyde 19, which was submitted to the Wittig reaction, providing the target iodoester 10, one of the Sonogashira reaction partners.

The synthesis of the Sonogashira reaction partner $\mathbf{1 1}$ was carried out starting from epoxide 20 [81], which reacted first with lithium acetylide and then with potassium carbonate for trimethylsilyl cleavage, giving 11 in 59\% overall yield (Scheme 5). 


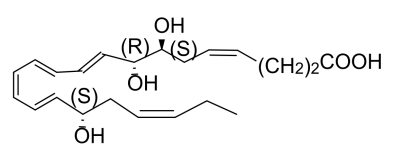

||

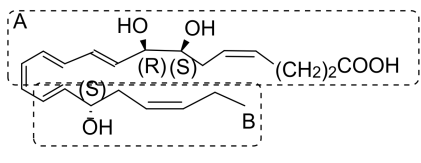

Structure of resolvin D1

A. Synthesis of precursor 5
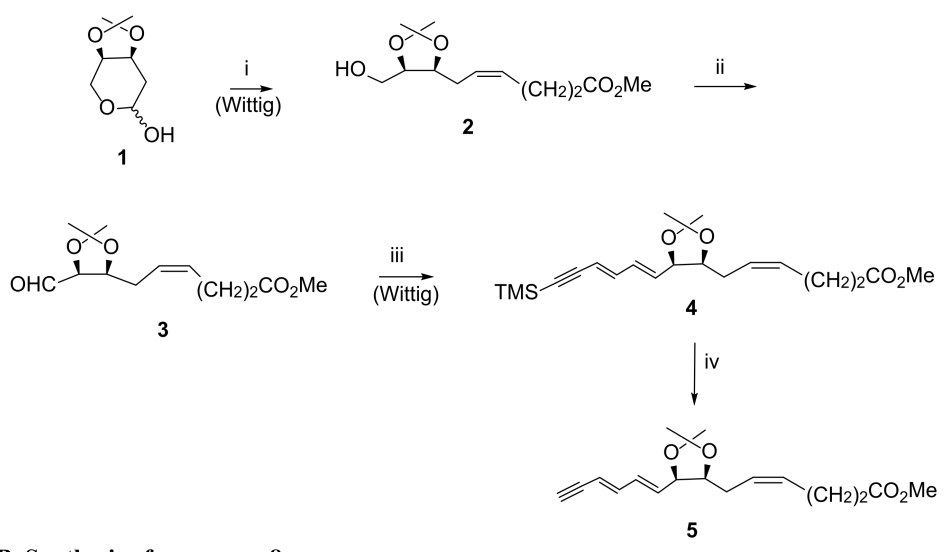

B. Synthesis of precursor 8

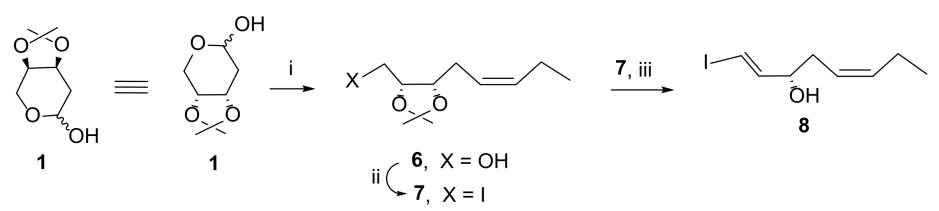

Sonogashira reaction and final steps
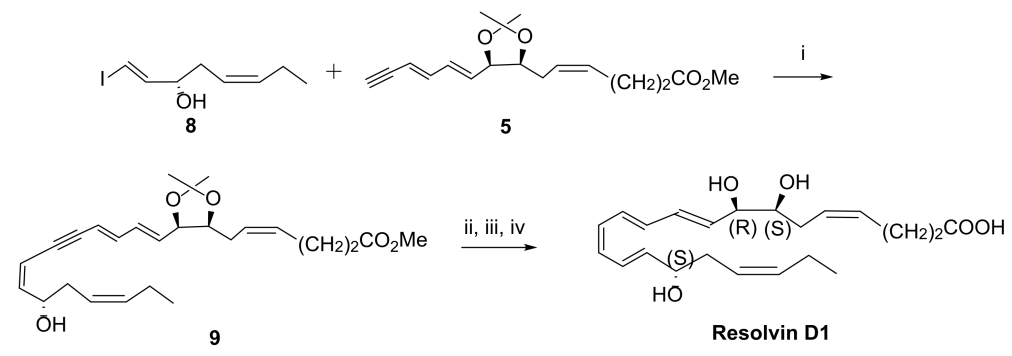

Scheme 4. A RvD1 total synthesis as reported in 2012 by Rodríguez and Spur [80] (A). Synthesis of compound 5. Reagents and conditions: i. $\mathrm{KN}(\mathrm{TMS})_{2}, \mathrm{MeO}_{2} \mathrm{C}-\left(\mathrm{CH}_{2}\right)_{2} \mathrm{CH}_{2} \mathrm{PPh}_{3}{ }^{+} \mathrm{Br}^{-}, \mathrm{THF},-70{ }^{\circ} \mathrm{C}$ to rt, $43 \%$; ii. Dess-Martin periodinane, $\mathrm{CH}_{2} \mathrm{Cl}_{2}, \mathrm{rt}, 84 \%$; iii. 1.TMS-C $\equiv \mathrm{C}-\mathrm{CH}=\mathrm{CHCH}_{2} \mathrm{PPh}_{3}{ }^{+} \mathrm{Br}^{-}$, $n \mathrm{BuLi}, \mathrm{THF},-70{ }^{\circ} \mathrm{C}$ to $0{ }^{\circ} \mathrm{C} ; 2$. $\mathrm{I}_{2}$, benzene, rt, $87 \%$; iv. $\mathrm{KF} 2 \mathrm{H}_{2} \mathrm{O}, 18$-crown-6, DMF, rt, $88 \%$. (B) RvD1 total synthesis as described in 2012 by Rodríguez and Spur [80]. (B). Synthesis of compound 8. Reagents and conditions: i. $\mathrm{CH}_{3} \mathrm{CH}_{2} \mathrm{CH}_{2} \mathrm{PPh}_{3}{ }^{+} \mathrm{Br}^{-}$, NaN(TMS) $)_{2}, \mathrm{Et}_{2} \mathrm{O},-78{ }^{\circ} \mathrm{C}$ to $\mathrm{rt}, 60 \%$; ii. $\mathrm{I}_{2}$, $\mathrm{Ph}_{3} \mathrm{P}$, imidazole, toluene, $60{ }^{\circ} \mathrm{C}, 82 \%$; iii. LDA, THF, $-78{ }^{\circ} \mathrm{C}, 40 \%$; Synthesis of RvD1 via Sonogashira reaction. Reagents and conditions: i. $\mathrm{Pd}\left(\mathrm{PPh}_{3}\right)_{4}, \mathrm{CuI}$, piperidine, benzene, rt, $86 \%$; ii. $\mathrm{CH}_{3} \mathrm{COCl}$ cat., $\mathrm{CH}_{3} \mathrm{OH}, 0{ }^{\circ} \mathrm{C}, 90 \%$; iii. $\mathrm{Zn}(\mathrm{Cu} / \mathrm{Ag}), \mathrm{CH}_{3} \mathrm{OH}, \mathrm{H}_{2} \mathrm{O}, 50{ }^{\circ} \mathrm{C}, 5 \mathrm{~h}, 67 \%$; iv. $\mathrm{LiOH} 1 \mathrm{~N}, \mathrm{CH}_{3} \mathrm{OH}, \mathrm{H}_{2} \mathrm{O}, 0{ }^{\circ} \mathrm{C}$, then sat. $\mathrm{NaH}_{2} \mathrm{PO}_{4}, 94 \%$. 


\section{Sonogashira reaction}<smiles>CC(=O)CCC=CCC(O[Sb])C(C=CC=CI)O[Sb]</smiles>

10

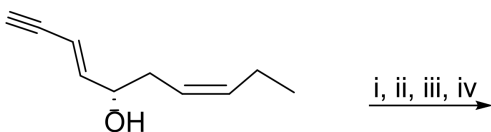

11<smiles>[R10][R17]</smiles>

Synthesis of iodoester 10

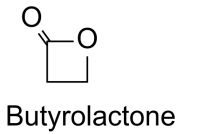

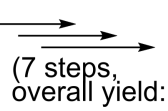
overall yield: $13.8 \%$ )<smiles>OCO</smiles>

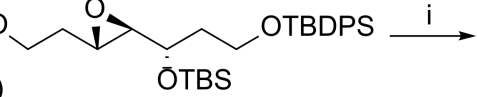

12

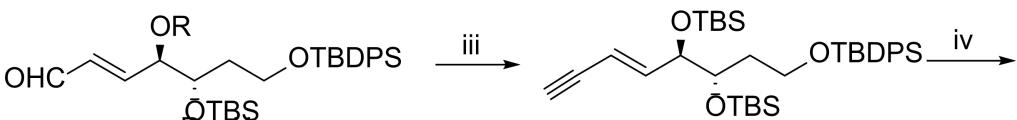
ii $\left(\begin{array}{ll}13, \\ R\end{array}=\right.$ TBS 15

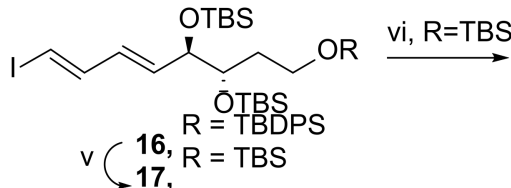

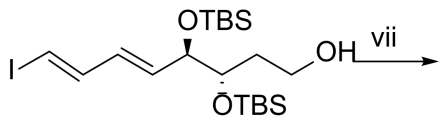

18

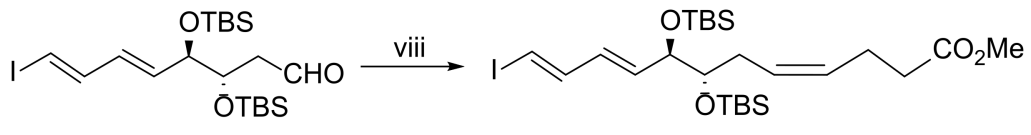
19

Synthesis of alcohol 11 with the terminal triple bond

TMS<smiles>CC=CCCC=O</smiles>

20

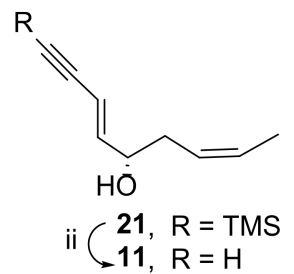

Scheme 5. Synthesis of RvD1, as reported by Kobayashi et al. [81]. Reagents and conditions. Sonogashira reaction: i. $\mathrm{Pd}\left(\mathrm{PPh}_{3}\right)_{4}, \mathrm{CuI}, t \mathrm{BuNH}_{2}, \mathrm{rt}, 15 \mathrm{~min}$; ii. TBAF, THF, rt, $2 \mathrm{~h}, 78 \%$ over two steps; iii. $\mathrm{Zn}(\mathrm{Cu} / \mathrm{Ag})$ (excess), $\mathrm{MeOH} / \mathrm{H}_{2} \mathrm{O}(1: 1), \mathrm{rt}, 5$ h, 93\%; iv. $\mathrm{LiOH}$, aq. $\mathrm{MeOH}, 42 \%$; Synthesis of iodoester 10: i. 1. $(\mathrm{COCl})_{2}, \mathrm{DMSO}, \mathrm{CH}_{2} \mathrm{Cl}_{2} ; 2$. $\mathrm{Net}_{3},-78{ }^{\circ} \mathrm{C}$ to $0{ }^{\circ} \mathrm{C}, 83 \%$; ii. TBSOTf, 2,6-lutidine, $92 \%$; iii. TMSCHN $2, \mathrm{LDA}, \mathrm{THF},-78^{\circ} \mathrm{C}$ to rt, $89 \%$; iv. $1 . \mathrm{Cp}_{2} \mathrm{ZrCl}_{2}, \mathrm{DIBAL}(1: 1), \mathrm{THF},-78^{\circ} \mathrm{C}$ to rt; 2. $\mathrm{I}_{2},-78{ }^{\circ} \mathrm{C}$ to rt, $75 \%$; v. 1 . TBAF, THF, $2 \mathrm{~h}, \mathrm{rt} ; 2$. TBSOTf, 2,6 -lutidine, $79 \%$; vi. PPTS (1.1. equiv.), $\mathrm{MeOH} / \mathrm{CH}_{2} \mathrm{Cl}_{2}, \mathrm{rt}, 3 \mathrm{~h}, 50 \%$; vii. $(\mathrm{COCl})_{2}$, DMSO; then $\mathrm{Net}_{3}$; viii. $\mathrm{Br}-\mathrm{Ph}_{3} \mathrm{P}^{+} \mathrm{CH}_{2} \mathrm{CH}_{2} \mathrm{CH}_{2} \mathrm{CO}_{2} \mathrm{Me}$, NaHMDS, THF, $-78{ }^{\circ} \mathrm{C}$ to $0{ }^{\circ} \mathrm{C}, 73 \%$ over the two steps; Synthesis of alcohol 11: i. TMSC $\equiv \mathrm{CH}, n \mathrm{BuLi}$, THF/HMPA (1:1), rt, 4 h; ii. $\mathrm{K}_{2} \mathrm{CO}_{3}, \mathrm{MeOH}, \mathrm{rt}, 1 \mathrm{~h}, 59 \%$ over the two steps. 


\subsubsection{Resolvin D2}

The first total synthesis of RvD2 was reported by Rodríguez and Spur in 2004 [85]. The key step is again a Sonogashira reaction, in which the iodoester 22 reacts with the terminal triple bond of the isopropylidene protected cis-diol $\mathbf{2 3}$ (Scheme 6). After deprotection of the triethylsilyl (TES) group with PPTS and acid hydrolysis of the isopropylidene, the triol $\mathbf{2 6}$ is reduced with $\mathrm{Zn}(\mathrm{Cu} / \mathrm{Ag})$, a stereospecific reaction affording the ester 27 in $70 \%$ yield, the hydrolysis of which provided resolvin D2.

Synthesis of resolvin D2 - Sonogashira reaction, reduction and deprotection steps

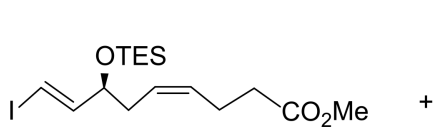

22

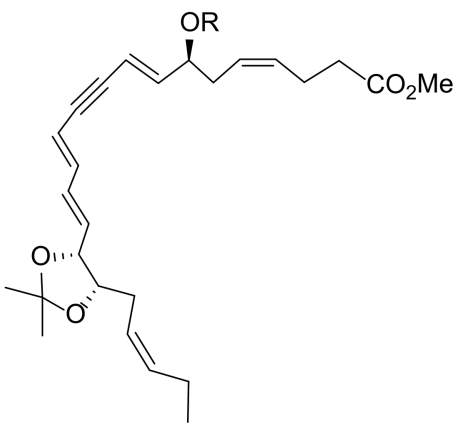

ii $24, R=T E S$

$25, \mathrm{R}=\mathrm{H}$

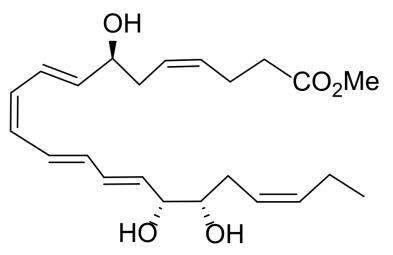

27

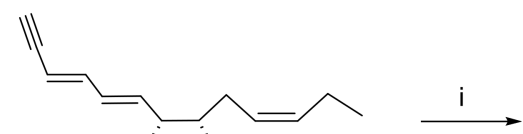

23

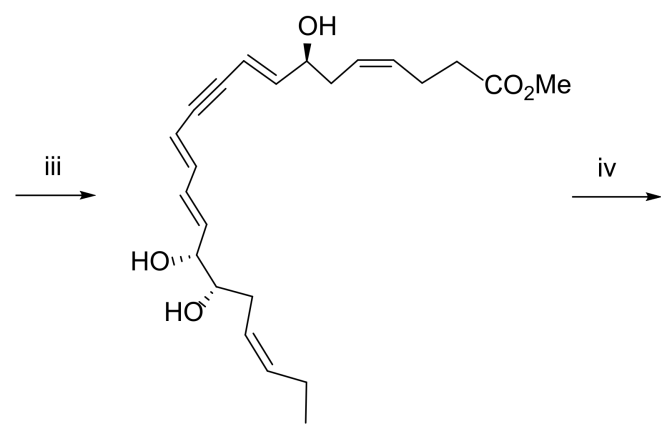

26
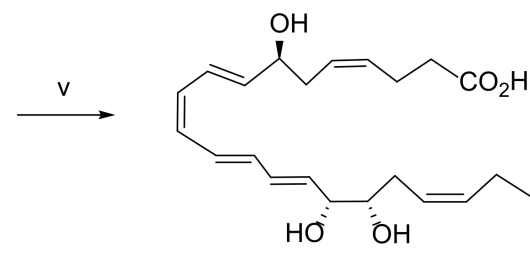

Resolvin D2

Scheme 6. Synthesis of resolvin D2 via Sonogashira reaction. Reagents and conditions: i. $\mathrm{Pd}\left(\mathrm{PPh}_{3}\right)_{4}$, $\mathrm{CuI}, \mathrm{n}-\mathrm{PrNH}_{2}$, benzene, rt; ii. pyridinium, $p$-toluenesulfonate, $\mathrm{CH}_{3} \mathrm{OH}$, rt; iii. $1 \mathrm{~N} \mathrm{HCl}, \mathrm{CH}_{3} \mathrm{OH} / \mathrm{H}_{2} \mathrm{O}$, rt; iv. $\mathrm{Zn}(\mathrm{Cu} / \mathrm{Ag})$, aq $\mathrm{CH}_{3} \mathrm{OH}, 40^{\circ} \mathrm{C}$; v. $1 \mathrm{~N} \mathrm{LiOH}, \mathrm{THF}, 0^{\circ} \mathrm{C}$, then EtOAc, satd $\mathrm{NaH}_{2} \mathrm{PO}_{4}$.

Starting with the pent-4-ynoic acid 28, that forms a dimagnesium complex with methylmagnesium bromide, alkylation proceeds via reaction with allyl bromide 29 in the presence of catalytic $\mathrm{CuBr}-\mathrm{Me}_{2} \mathrm{~S}$, furnishing oct-7-en-4-ynoic acid 30, esterified in situ to give 31 (Scheme 7A). Epoxidation with $m$-chloroperbenzoic acid ( $m \mathrm{CPBA}$ ) provided epoxide racemic mixture 32. The hydrolytic kinetic resolution with water in the presence of $5 \%$ $(R, R)$-salen-Co (III)(OAc) catalyst in diethyl ether furnished diol 33 with $>94 \%$ enantiomeric excess, separated by column chromatography from epoxide $32(R)$. Both hydroxy groups were then protected by reaction with triethylsilyl chloride, followed by reduction of the triple bond using the Lindlar catalyst to afford quantitatively the ester $\mathbf{3 5}$ with a cis-double bond. Chemoselective Swern oxidation furnished aldehyde 36 in 54\% yield, which was subjected to Takai olefination to give 22 in $50 \%$ yield. 
A. Synthesis of iodoester 22

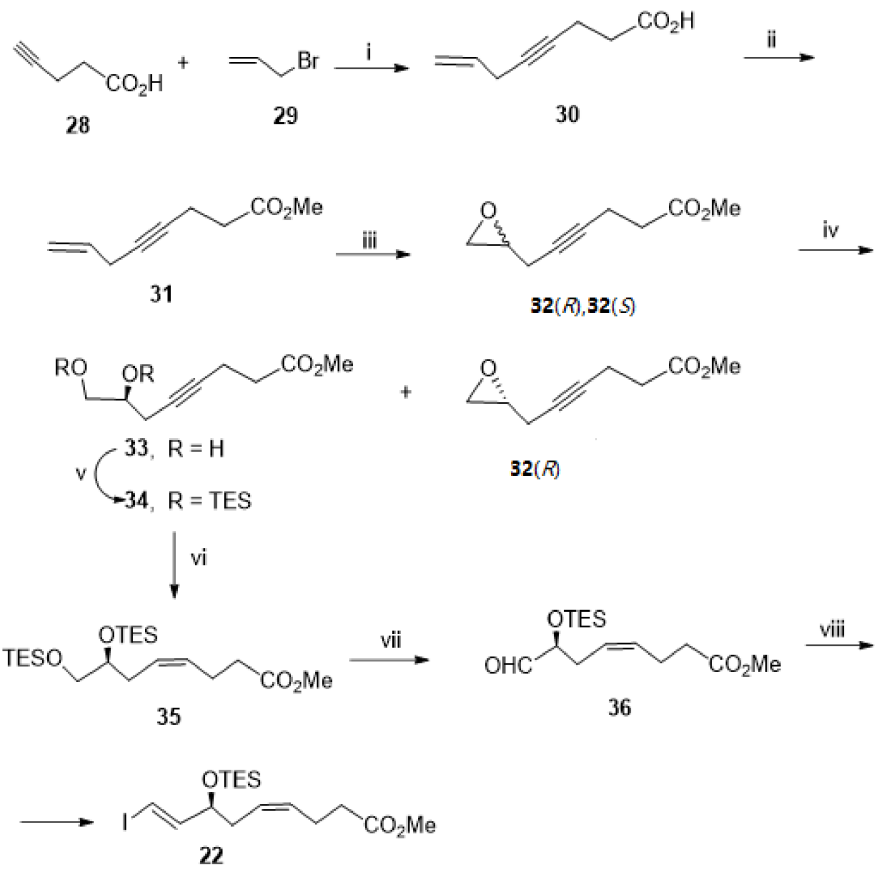

B. Synthesis of compound 23 embodying the terminal triple bond<smiles>CC#CCC/C=C/CC1OC(C)(C)O[C@@H]1CO</smiles>

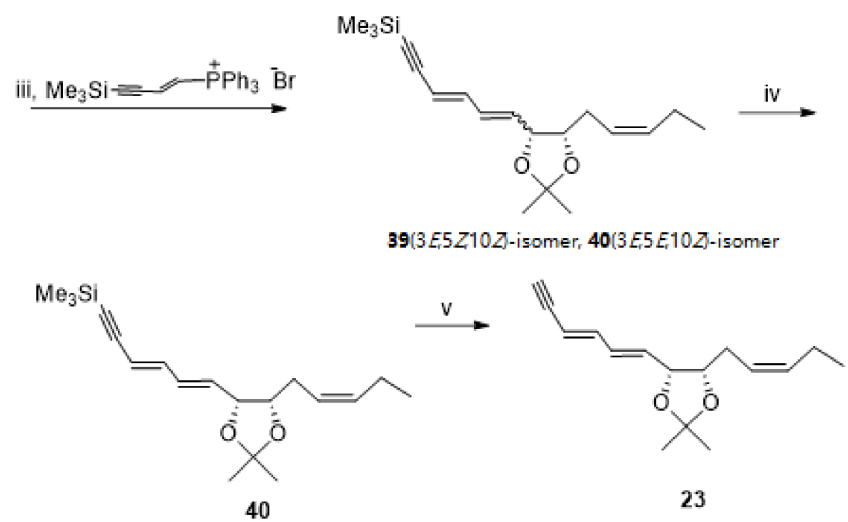

Scheme 7. (A) Synthesis of iodoester 22. Reagents and conditions: i. $\mathrm{MeMgBr}, \mathrm{CuBr}-\mathrm{Me}_{2} \mathrm{~S}, \mathrm{THF}, 0{ }^{\circ} \mathrm{C}$ to rt; ii. $10 \% \mathrm{TMSCl}, \mathrm{MeOH}, 2$,2-dimethoxypropane, rt; iii. $m \mathrm{CPBA}, \mathrm{NaHCO}_{3}, \mathrm{CH}_{2} \mathrm{Cl}_{2}, 0{ }^{\circ} \mathrm{C}$ to rt; iv. $(R, R)$-(salen) $\mathrm{CO}(\mathrm{III})(\mathrm{OAc})$ catalyst, $\mathrm{Et}_{2} \mathrm{O} / \mathrm{H}_{2} \mathrm{O}, 0{ }^{\circ} \mathrm{C}$ to $\mathrm{rt}$; v. TESCl, imidazole, $\mathrm{Et}_{3} \mathrm{~N}, \mathrm{DMF}, 0{ }^{\circ} \mathrm{C}$ to $\mathrm{rt}, 84 \%$; vi. Lindlar catalyst, $\mathrm{H}_{2}, \mathrm{Et}_{3} \mathrm{~N}$, hexane, quantitative yield; vii. $(\mathrm{COCl})_{2}, \mathrm{DMSO}, \mathrm{CH}_{2} \mathrm{Cl}_{2}$, $\mathrm{Et}_{3} \mathrm{~N},-78{ }^{\circ} \mathrm{C}$ to rt, $54 \%$; viii. $\mathrm{CrCl}_{2}, \mathrm{CHI}_{3}, \mathrm{THF}, 0{ }^{\circ} \mathrm{C}, 50 \%$. (B) Synthesis of compound 23 embodying the terminal triple bond. Reagents and conditions: i. $\mathrm{CH}_{3} \mathrm{CH}_{2} \mathrm{CH}_{2} \mathrm{Ph}_{3} \mathrm{P}^{+} \mathrm{Br}^{-}, \mathrm{NaN}(\mathrm{TMS})_{2}, \mathrm{Et}_{2} \mathrm{O}$, $-78{ }^{\circ} \mathrm{C}$ to $0{ }^{\circ} \mathrm{C}$; ii. PCC, $\mathrm{NaOAc}, \mathrm{CH}_{2} \mathrm{Cl}_{2}, 70 \%$; iii. BuLi, THF, $-78{ }^{\circ} \mathrm{C}$ to $0{ }^{\circ} \mathrm{C}$; iv. $\mathrm{I}_{2}$, benzene, rt; v. $\mathrm{KF}$, 18-crown-6, DMF, rt.

The preparation of Sonogashira reagent 23 was carried out starting with Wittig of the sugar 1 with the phosphorane resulting from propyltriphenylphosphonium bromide 
treatment with the base, furnishing the unsaturated primary alcohol 6 with a cis-double bond (Scheme 7B). Oxidation with pyridinium chlorochromate (PCC) afforded aldehyde 38 isolated in $70 \%$ yield. Wittig reaction with the phosphorane, formed by butyl lithium treatment of [(2E)-5-trimethylsilylpent-2-en-4-ynyl] triphenylphosphonium bromide, gave a mixture of isomers differing in the $(Z)$, and the $(E)$-configuration of the double bond formed, but with a catalytic amount of iodine in benzene, isomerization occurred, and only the desired Wittig product 40 was obtained. Cleavage of TMS was accomplished with potassium fluoride in dimethylformamide and 5\% of 18-crown- 6 ether to give the target compound 23 in high yield.

In 2013, Rizzacasa et al. [86] disclosed the total synthesis of RvD2 by a convenient and high yield approach, also based on a Sonogashira coupling. By coupling the hydroxyester 41 embodying the triple bond with the iodide 42, catalysed by (Ph3P)2PdCl2/CuI, intermediate 43 was formed in high yield (Scheme 8). Isopropylidene hydrolysis gave triol 44 also in high yield, and reduction of the triple bond with $\mathrm{Zn}(\mathrm{Cu} / \mathrm{Ag})$ afforded the ester 45 in $76 \%$ yield. Ester hydrolysis with lithium hydroxide $1 \mathrm{M}$ furnished resolvin D2 with the overall yield of $43.4 \%$. This methodology has the advantage of reducing the number of steps from five to four, when compared with the first total synthesis previously described.
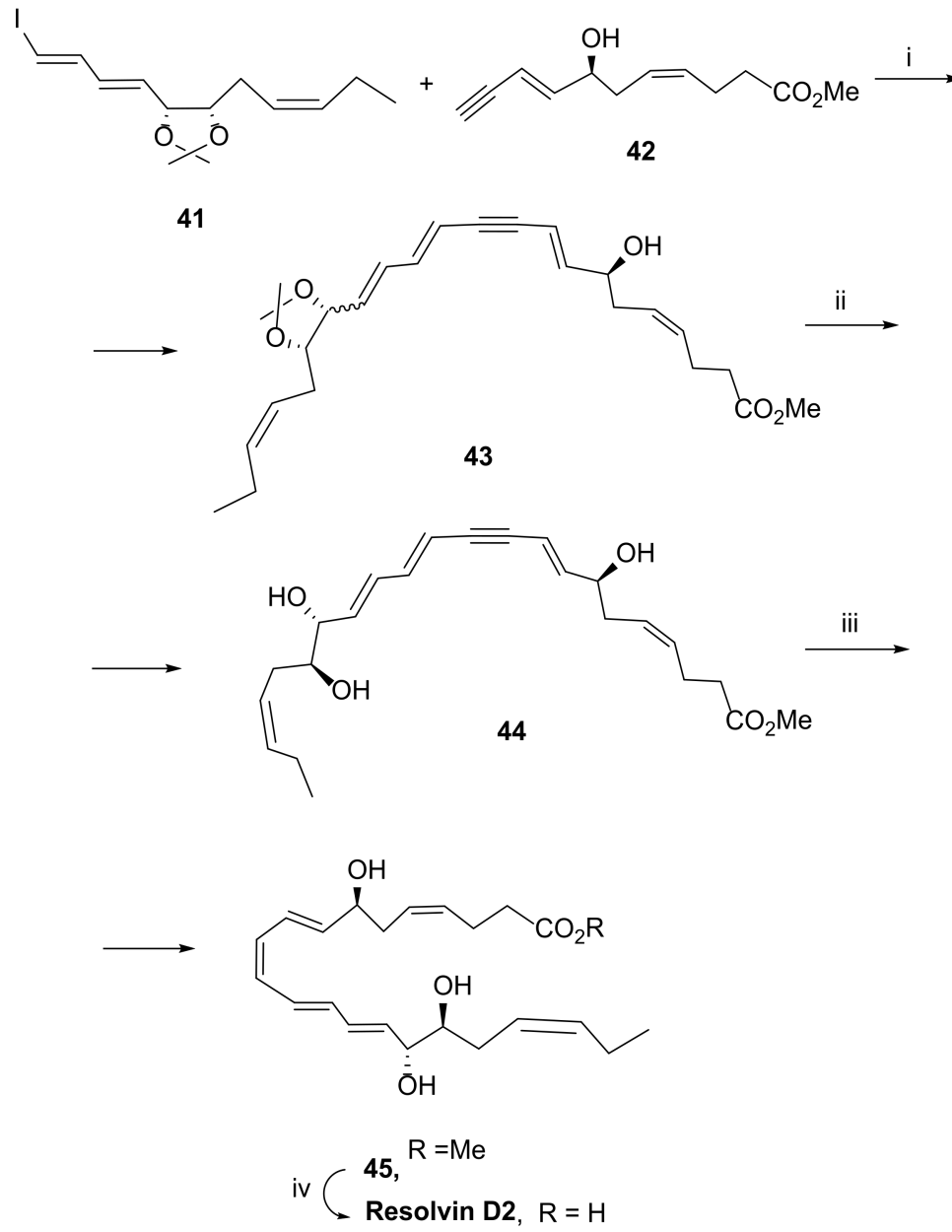

Scheme 8. Synthesis of resolvin D2, as reported by Rizzacasa et al. [86]. Reagents and conditions: i. $\mathrm{Ph}_{3} \mathrm{PdCl}_{2}, \mathrm{CuI}, \mathrm{Et}_{3} \mathrm{~N}, 0{ }^{\circ} \mathrm{C}$ to rt, $83 \%$; ii. $\mathrm{MeOH}, \mathrm{HCl}, \mathrm{rt}, 85 \%$; iii. $\mathrm{Zn}(\mathrm{Cu} / \mathrm{Ag}), \mathrm{MeOH}, \mathrm{H}_{2} \mathrm{O}, 76 \%$; iv. $\mathrm{LiOH}, 1 \mathrm{M}$, THF, $0{ }^{\circ} \mathrm{C}, 81 \%$.

The preparation of substrates 41 and 42 is described in Scheme 9A,B, respectively. The synthesis of compound $\mathbf{4 1}$ started by asymmetric dihydroxylation of compound 31 [85] catalysed by ADmix- $\alpha$, furnishing diol 46 in 69\% yield. After protection of the hydroxy groups by reaction with triethylsilyl chloride, partial reduction of the triple bond succeeded 
with sodium borohydride and nickel acetate in ethylenediamine (EDA), an efficient system for producing pure $(Z)$-alkenes, which afforded the unsaturated ester 48 in $73 \%$ yield. In agreement with the findings of Rodríguez et al. [87], Swern oxidation of 48 afforded the aldehyde 49 in high yield, which reacted then with the Wittig reagent to give as major product the methyl ester 50 with the $(4 Z, 8 E)-4,8$-diene functionality. Desilylation with TBAF gave $\mathbf{4 1}$ in $15.2 \%$ overall yield starting from compound 31 .

A. Synthesis of preeursor 41
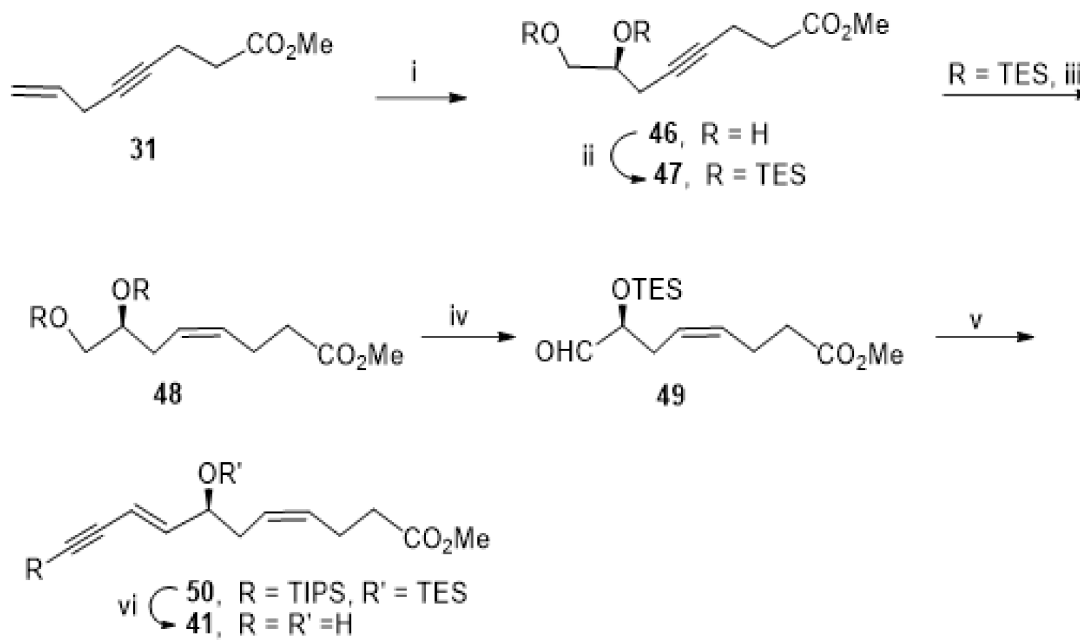

B. Synthesis of precursor 42

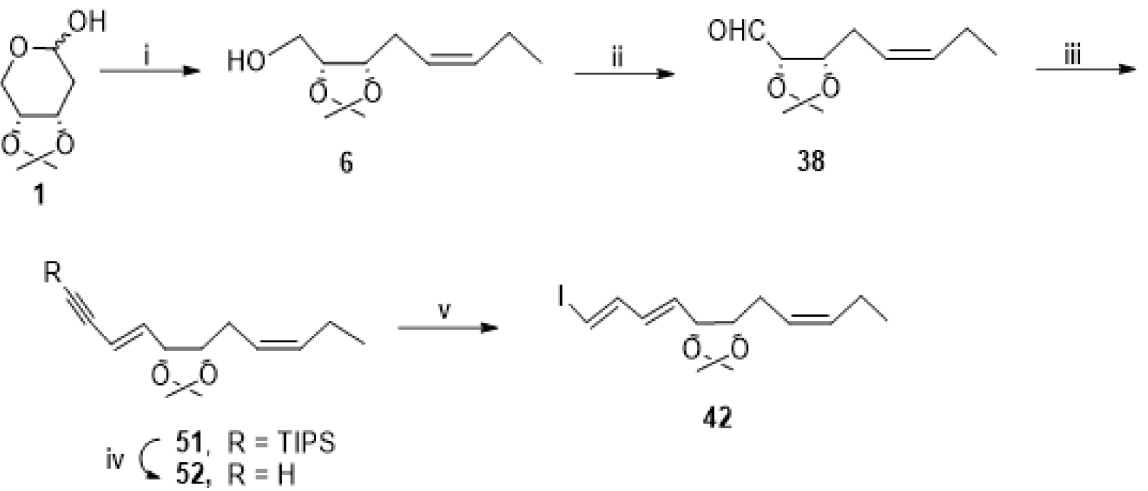

Scheme 9. Preparation of precursors 41 (A) and 42 (B), as reported by Rizzacasa et al. [86]. Reagents and conditions: (A). i. Admix $-\alpha, \mathrm{MeSO}_{2} \mathrm{NH}_{2}, \mathrm{tBuOH}, \mathrm{H}_{2} \mathrm{O}, 69 \%$; ii. TESCl, imidazole, 93\%; iii. $\mathrm{Ni}(\mathrm{OAc})_{2} .4 \mathrm{H}_{2} \mathrm{O}, \mathrm{NaBH}_{4}, \mathrm{EDA}, \mathrm{MeOH}, 73 \%$; iv. $(\mathrm{COCl})_{2}, \mathrm{DMSO}, \mathrm{Et}_{3} \mathrm{~N}, \mathrm{CH}_{2} \mathrm{Cl}_{2}, 78 \%$; v. 1. TIPS- $\equiv-\mathrm{CH}_{2} \mathrm{PPh}_{3}{ }^{+} \mathrm{Br}^{-}$, LiHMDS, $-78{ }^{\circ} \mathrm{C}$, then addition of $38,-40{ }^{\circ} \mathrm{C}$, $(3 E, 8 Z)$-isomer $49 \%$ and $(3 Z, 8 Z)$-isomer $12 \%$; vi. TBAF. (B). $\mathrm{CH}_{3} \mathrm{CH}_{2} \mathrm{CH}_{2} \mathrm{PPh}_{3}{ }^{+} \mathrm{Br}^{-}$, NaHMDS, $-78^{\circ} \mathrm{C}$ to $0{ }^{\circ} \mathrm{C}, 74 \%$; ii. DMP, 93\%; iii. TIPS- $\equiv-\mathrm{CH}_{2} \mathrm{PPh}_{3}{ }^{+} \mathrm{Br}^{-}, \mathrm{nBuLi}, \mathrm{THF},-40{ }^{\circ} \mathrm{C}$ to $0{ }^{\circ} \mathrm{C},(1 E, 3 E, 8 Z)$-isomer $57 \%,(1 Z, 3 E, 8 Z)-$ isomer $26 \%$; iv. $\mathrm{TBAF}, 73 \%$; v. 1 . $\mathrm{ZrCp}_{2} \mathrm{Cl}_{2}, \mathrm{iBu}_{2} \mathrm{AlH}, \mathrm{THF}, 0{ }^{\circ} \mathrm{C} ; 2 . \mathrm{I}_{2},-78{ }^{\circ} \mathrm{C}, 64 \%$.

Synthesis of 42 (Scheme 9B) started from compound 6, previously reported by Rodríguez and Spur (Scheme 7B) [85]. Oxidation with Dess-Martin periodinane (DMP) afforded the aldehyde 38 in very high yield (93\%), when compared with the yield of 70\%, previously reported when oxidation was carried out with PCC [85]. Introduction of the enyne moiety by Wittig reaction gave the required 3(E)-isomer $\mathbf{5 1}$ as the major product, in $57 \%$ isolated yield. Desilylation with TBAF was followed by stereoselective reduction of the triple bond with the system $\mathrm{ZrCp} 2 \mathrm{Cl}_{2}$ and DIBAL, furnishing product $\mathbf{4 2}$, containing the required trans-iododiene moiety, in good yield. 


\subsubsection{Resolvin D3}

In 2013, Petasis and co-workers developed the first total synthesis of RvD3. The convergent and stereocontrolled synthetic pathway (Schemes 10-12) involves two Sonogashira cross-coupling reactions introducing key triple bonds that are stereoselectively reduced with the mild reagent $\mathrm{Zn}(\mathrm{Cu} / \mathrm{Ag})$ to generate triene and diene moieties in the final steps, aiming at preventing $Z / E$ isomerization. Starting from carboxy- $\gamma$-butyrolactone 53 (Scheme 10A) [which (S)-configuration generates the 4(S) configuration of RvD3], lactone ring opening, and esterification, followed by regioselective reduction with borane dimethyl sulfide in the presence of catalytic sodium borohydride, gave diol 55 in high yield. Silylation of the free hydroxy groups was followed by regioselective desilylation of the primary position with camphorsulfonic acid (CSA). After Swern oxidation of the primary alcohol in very high yield, Corey-Fuchs homologation using LDA as base gave compound 58 in $62 \%$ yield, which is the cross-coupling partner of the first Sonogashira reaction. Its coupling partner is compound 65 , prepared from epoxide 60 with $(R)$-configuration, which is maintained along the synthetic pathway, generating the $11(R)$-chirality centre of RvD3. Nucleophilic attack of $\mathbf{6 0}$ with TMS-acetylide anion followed by silylation of the formed hydroxy group gave compound 61. Regioselective desilylation with CSA was followed by Swern oxidation to give the aldehyde 63, which reacted with formylmethylenetriphenylphosphorane, affording the trans-isomer 64 in $86 \%$ yield. Finally, Takai olefination of 64 provided 65 as the major product from a 9:1 mixture of the $E / Z$ isomers, embodying the iododiene moiety required for the Sonogashira reaction and the terminal alkyne for the second Sonogashira reaction, which is required for the total synthesis of RvD3.

Sonogashira cross-coupling of $\mathbf{6 5}$ and 58 was catalysed by $\mathrm{Pd}\left(\mathrm{Ph}_{3}\right)_{4} /$ cat CuI in triethylamine and benzene, affording a very high yield (92\%) of enantiomerically pure compound 66, which was desilylated with sodium carbonate in methanol, giving 67 also in very high yield.

The preparation of the 73 cross-coupling partner for the second Sonogashira reaction used, as starting material, the epoxide enantiomer 68 (Scheme 11), which reacted with lithiated but-1-yne attacking the less hindered carbon of the epoxide and proving alcohol 69 with the required $(S)$ configuration. Protection of the secondary alcohol with tertbutyldiphenylsilyl (TBDPS) group was followed by TBS cleavage to afford the primary alcohol 70. Hydrogenation with Lindlar catalyst resulted in a stereoselective reduction of the triple bond, giving alcohol $\mathbf{7 1}$ in very high yield, embodying a cis-double bond. Swern oxidation gave the aldehyde precursor in $90 \%$, and the stereoselective olefination with $\mathrm{CH}_{3} \mathrm{I} / \mathrm{CrCl}_{2}$, the so-called Takai olefination, afforded precursor $\mathbf{7 2}$ in good yield. The protecting group TBDPS was removed, and the secondary position protected with TBS to give 73 , because in the final assembly of RvD3, removal of TBDPS with TBAF led to product decomposition. The Sonogashira cross-coupling of 73 and 67 succeeded in very high yield (Scheme 12). TBS removal also succeeded in giving the expected deprotected product 75 , although in low yield $(27 \%)$, and the target molecule was prepared by triple bond reduction with $\mathrm{Zn}(\mathrm{Cu} / \mathrm{Ag})$ and ester hydrolysis, in $22 \%$ yield over the last two steps.

In 2020, Anderson and co-workers [88] developed an alternative synthetic pathway, leading to a very original and concise synthesis of RvD3, by applying a new approach based on the stereoselectivity of the cross-coupling of cyclic alkenylsiloxanes, used to specifically control the stereochemistry of the installed (Z)-double bonds (Scheme 13). They conceived a tail-to-head strategy with the building blocks 76, the RvD3 tail fragment for the cross-coupling with the six-membered ring siloxane 77 , the middle fragment that reacts with 78, and the five-membered ring siloxane B head fragment to obtain protected RvD3, which, in one single step, by reaction with aqueous lithium hydroxide, provided RvD3 in very high yield. Synthesis of the building block $\mathbf{7 6}$ (Scheme 13) started with the Sharpless epoxidation of the allyl alcohol $\mathbf{8 1}$ to afford the correct configuration of the epoxide, glowed by Garegg iodination of the primary alcohol. Base mediated the regioselective epoxide ring opening, and elimination afforded alcohol 83 , embodying the desired $(E)$-iodoalkene moiety. Synthesis of 77 started with (2E,4E)-5-bromopenta-2,4-dienal, prepared by treatment of 
pyridinium-1-sulfonate sodium hydroxide to afford glutaconaldehyde potassium salt, followed by bromination with triphenylphosphonium bromide [89] (Scheme 13). Addition of allyl magnesium bromide, and Sharpless resolution gave the enantio-enriched ( $97 \%$ ee) alcohol 88 in 38\% yield. Reaction with dimethylvinylsilyl chloride gave the intermediate ether for the successful and high yield ring-closing metathesis mediated by the Schrock catalyst. The preparation of $\mathbf{7 8}$ started with the reaction of the commercially available acid chloride $\mathbf{8 9}$ with [(benzyldimethylsilyl)ethynyl] magnesium bromide to afford ketone 90 in $57 \%$ yield. Stereoselective reduction by Noyori asymmetric transfer hydrogenation gave the alcohol in 97\% yield and 99\% enantiomer excess, which was then esterified with acetic anhydride and dimethylaminopyridine (DMAP). Stereoselective reduction of the triple bond to the (Z)-double bond was challenging and succeeded in 83\% yield (Z/E:20/1). Debenzylation, deacetylation, and cyclization occurred by treatment with TBAF, which afforded the building block $\mathbf{7 8}$ in quantitative yield.
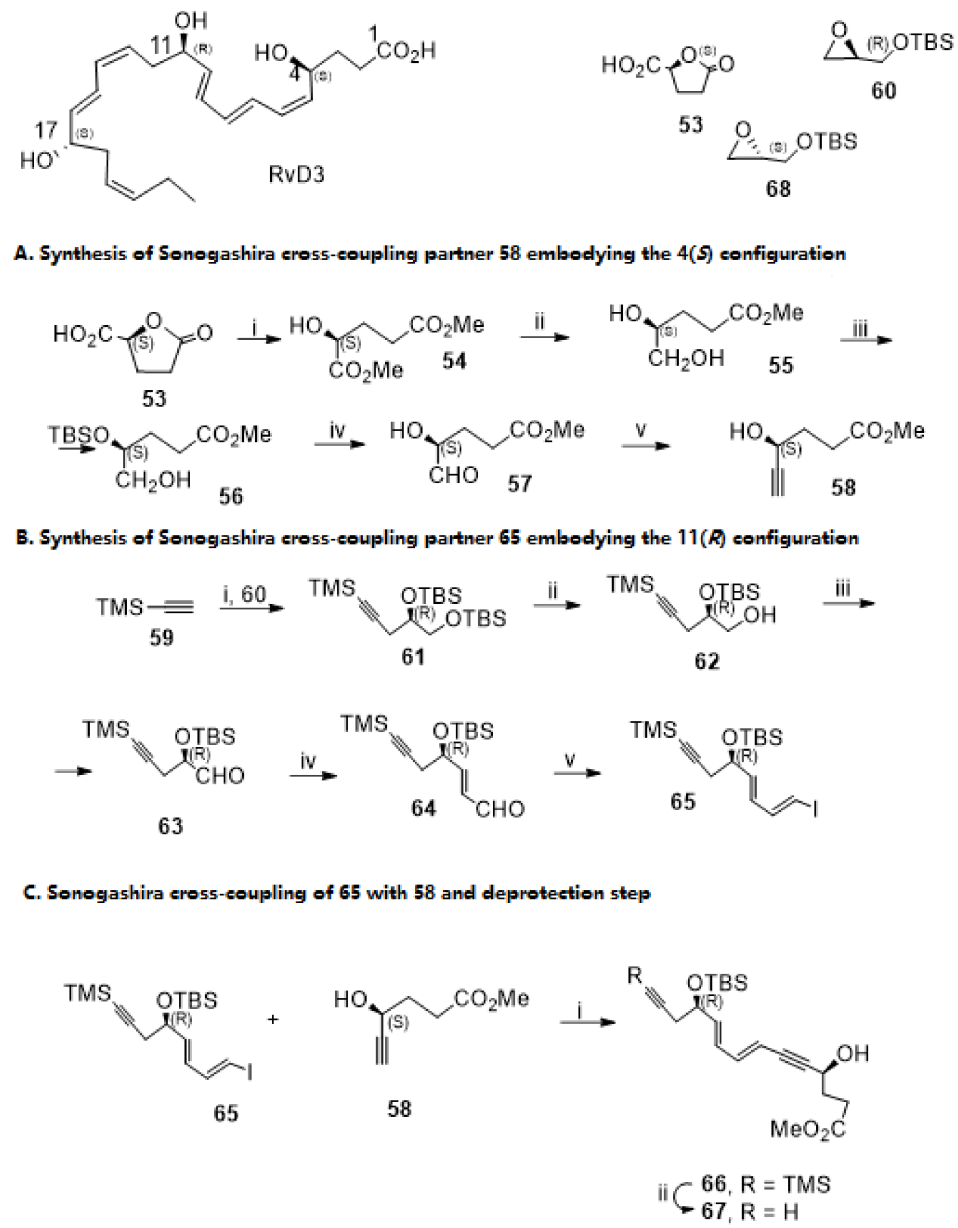

Scheme 10. Synthesis of Sonogashira cross-coupling partners 58 and 65, Sonogashira reaction, and deprotection step to afford ester 67. Reagents and conditions: (A). i. $\mathrm{MeOH}, \mathrm{HCl}$, cat. 96\%; ii. $\mathrm{BH}_{3}$. DMS, $\mathrm{NaBH}_{4}, \mathrm{THF}, 10{ }^{\circ} \mathrm{C}, 86 \%$; iii. 1. TBSCl, imidazole, DMAP, $\mathrm{CH}_{2} \mathrm{Cl}_{2} ; 2$. CSA, $\mathrm{CH}_{2} \mathrm{Cl}_{2} / \mathrm{MeOH}, 57 \%$; iv. $(\mathrm{COCl})_{2}, \mathrm{DMSO}, \mathrm{Et}_{3} \mathrm{~N}, \mathrm{CH}_{2} \mathrm{Cl}_{2},-78{ }^{\circ} \mathrm{C}, 98 \%$; v. $1 . \mathrm{PPh}_{3}, \mathrm{CBr}_{4}, \mathrm{CH}_{2} \mathrm{Cl}_{2}, 0{ }^{\circ} \mathrm{C} ; 2 . \mathrm{LDA}, \mathrm{THF},-78{ }^{\circ} \mathrm{C}$, $62 \%$. (B). i.nBuLi, $\mathrm{BF}_{3} . \mathrm{Et}_{2} \mathrm{O}, \mathrm{THF},-78^{\circ} \mathrm{C}$; 2. 60; 3. TBSCl, imidazole, DMAP, $\mathrm{CH}_{2} \mathrm{Cl}_{2}, 63 \%$; ii. CSA, rt, $\mathrm{CH}_{2} \mathrm{Cl}_{2} / \mathrm{MeOH}, 77 \%$; iii. $(\mathrm{COCl})_{2}, \mathrm{DMSO}, \mathrm{Et}_{3} \mathrm{~N}, \mathrm{CH}_{2} \mathrm{Cl}_{2},-78{ }^{\circ} \mathrm{C}, 90 \%$; iv. $\mathrm{Ph}_{3} \mathrm{P}=\mathrm{CHCHO}, \mathrm{PhMe}$, $2 \mathrm{~h}, 83 \%$; v. $\mathrm{CHI}_{3}, \mathrm{CrCl}_{2}, \mathrm{THF},{ }^{\circ} \mathrm{C}, 84 \%$; (C). i. $\mathrm{Pd}\left(\mathrm{PPh}_{3}\right)_{4}, \mathrm{CuI}$ cat., $\mathrm{Et}_{3} \mathrm{~N}, \mathrm{PhH}, \mathrm{rt}, 92 \%$; ii. $\mathrm{Na}_{2} \mathrm{CO}_{3}$, $\mathrm{MeOH}, \mathrm{rt}, 91 \%$. 
Synthesis of Sonogashira cross-coupling partner 73

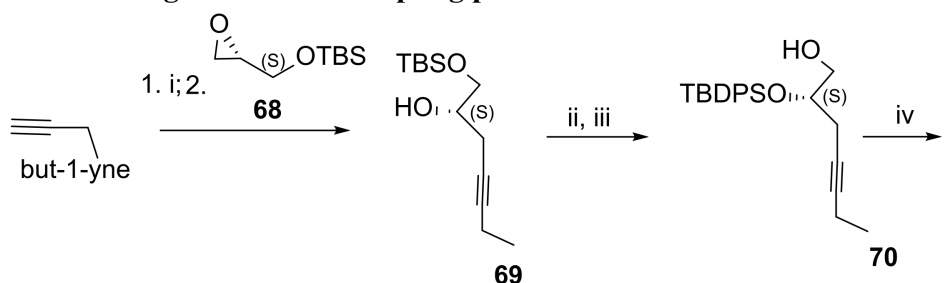

69

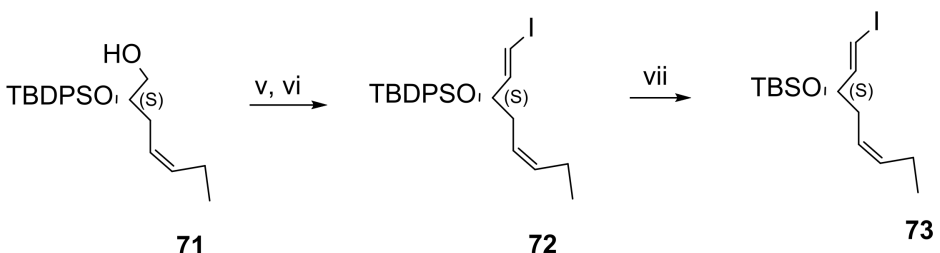

Scheme 11. Synthesis of Sonogashira cross-coupling partner 73. Reagents and conditions: i. $\mathrm{nBuLi} \mathrm{BF}_{3}$ $\mathrm{Et}_{2} \mathrm{O}, \mathrm{THF},-78{ }^{\circ} \mathrm{C}$; ii. 68, 73\%; ii. TBDPSCl, imidazole, DMAP, $\mathrm{CH}_{2} \mathrm{Cl}_{2}, 89 \%$; iii. CSA, $\mathrm{CH}_{2} \mathrm{Cl}_{2} / \mathrm{MeOH}$, rt, $97 \%$; iv. $\mathrm{H}_{2}$ /Lindlar cat., EtOAc, rt, $94 \%$; v. $(\mathrm{COCl})_{2}, \mathrm{DMSO}_{3} \mathrm{Et}_{3} \mathrm{~N}, \mathrm{CH}_{2} \mathrm{Cl}_{2},-78{ }^{\circ} \mathrm{C}, 90 \%$; vi. $\mathrm{CHI}_{3}$, $\mathrm{CrCl}_{2}$, THF, $0{ }^{\circ} \mathrm{C}, 59 \%$; vii. 1 . TBAF, THF, rt; 2 . TBSOTf, lutidine, $\mathrm{CH}_{2} \mathrm{Cl}_{2}, \mathrm{rt}, 69 \%$.

Sonogashira cross-coupling of 73 with 67, triple bond reduction and deprotection steps

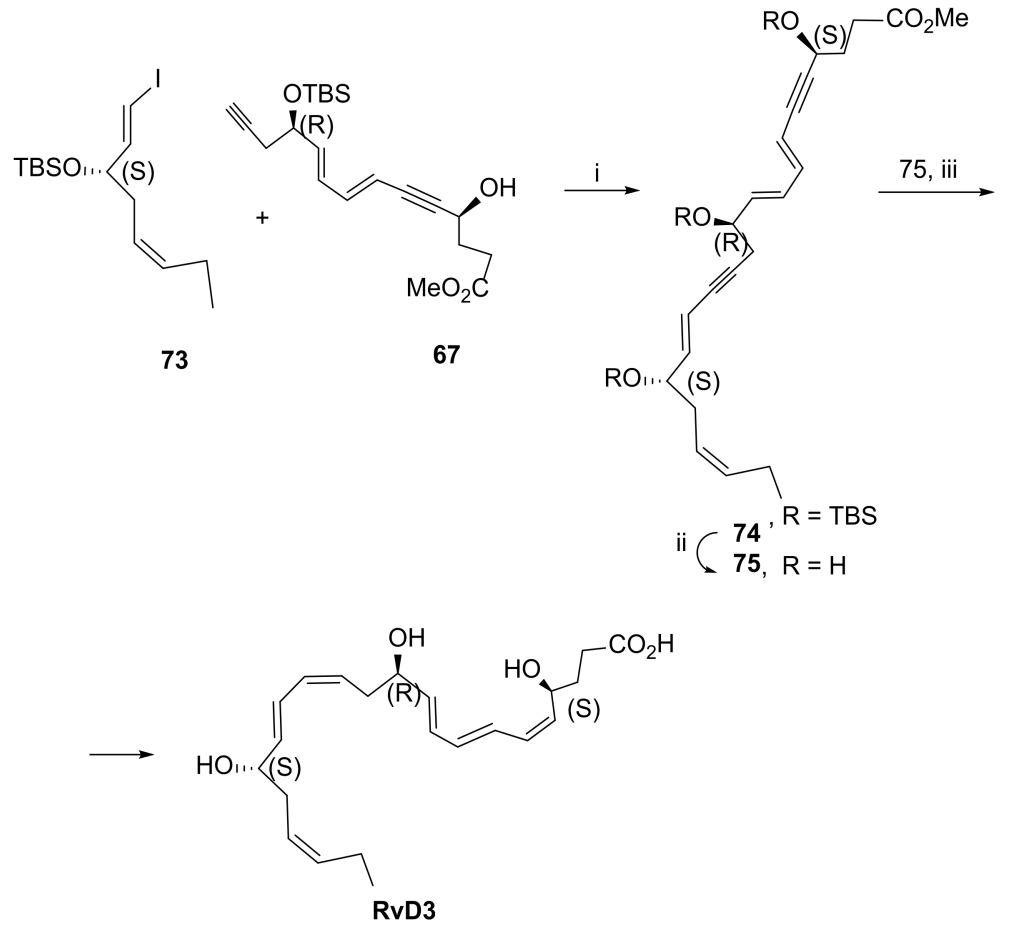

Scheme 12. Synthesis of RvD3 - the second Sonogashira reaction. i. $\mathrm{Pd}\left(\mathrm{PPh}_{3}\right)_{4}, \mathrm{CuI}$ cat., $\mathrm{Et}_{3} \mathrm{~N}, \mathrm{PhH}$, rt, $92 \%$; ii. TBAF, THF, 27\%; iii. 1. $\mathrm{Zn} / \mathrm{Cu} / \mathrm{Ag}, \mathrm{MeOH} / \mathrm{H}_{2} \mathrm{O} ; 2$. $\mathrm{NaOH}, \mathrm{H}_{2} \mathrm{O}, \mathrm{MeOH}, 22 \%$ (over the two steps). 


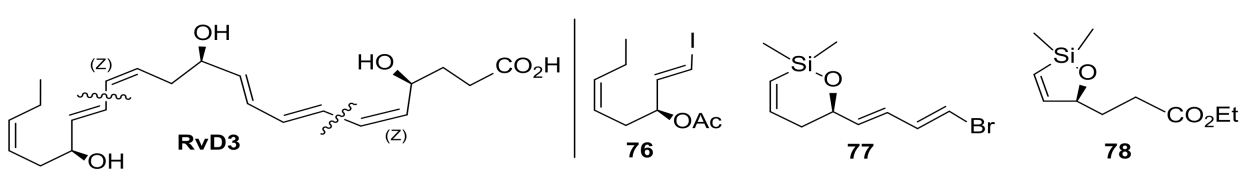

Total synthesis
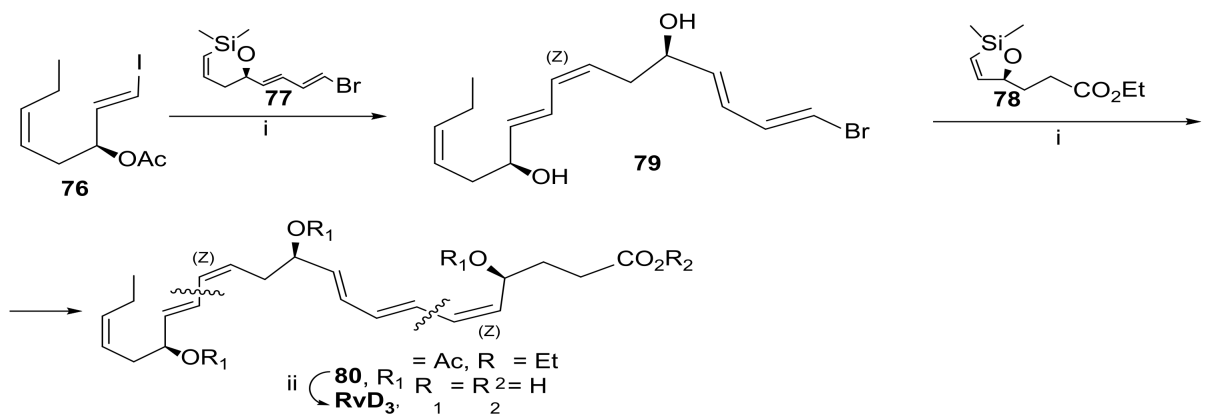

A.

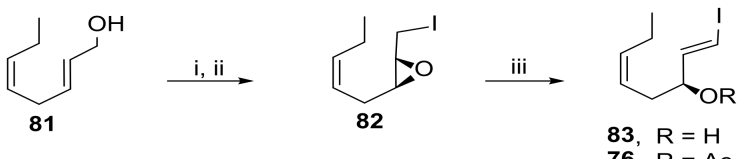

B.

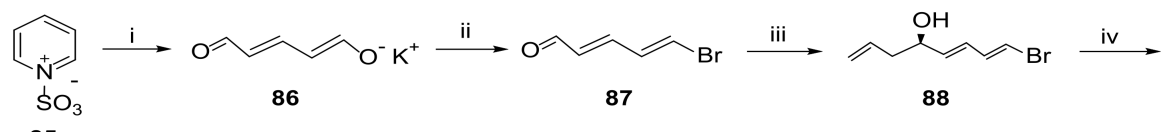

85

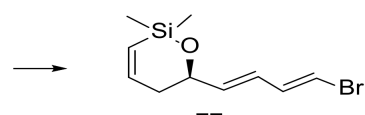

77
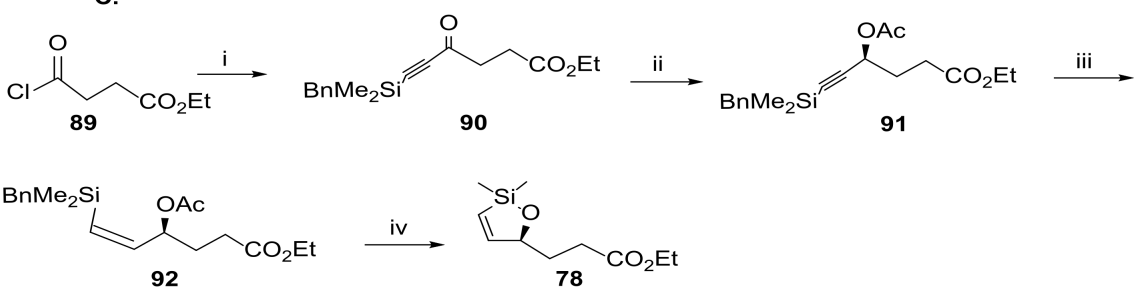

Scheme 13. Synthesis of RvD3, as reported by Anderson and co-workers [88], and preparation of the building blocks 76 (A), 77 (B), and 78 (C). Reagents and conditions: Total synthesis: i. 1. Pd(dba) TBAF, THF, $16 \mathrm{~h}$; 2. $\mathrm{Ac}_{2} \mathrm{O}$, py, $\mathrm{CH}_{2} \mathrm{Cl}_{2}, 56 \%$ for $\mathbf{7 9}$ and $32 \%$ for 80, both over the two steps ii. $\mathrm{LiOH}, \mathrm{THF} / \mathrm{H}_{2} \mathrm{O}$ (1:1), 99\%; (A). Preparation of 76: i. 1. Ti(O-iPr) $)_{4},(\mathrm{~L})-(+)-\mathrm{DIPT}, \mathrm{TBHP}, 3 \AA \mathrm{MS}$, $\mathrm{CH}_{2} \mathrm{Cl}_{2},-20{ }^{\circ} \mathrm{C}, 75 \%, 92 \%$ ee; $2 . \mathrm{I}_{2}, \mathrm{PPh}_{3}$, imidazole, $\mathrm{CH}_{2} \mathrm{Cl}_{2}, 53 \%$; iii. $\mathrm{Ac}_{2} \mathrm{O}, \mathrm{DMAP}, \mathrm{Et}_{3} \mathrm{~N}, \mathrm{CH}_{2} \mathrm{Cl}_{2}$, $0{ }^{\circ} \mathrm{C}$ to rt, 2 h, 93\%; (B). Preparation of 77. i. $\mathrm{KOH}, 58 \%$ [X8]; ii. $\mathrm{Ph}_{3} \mathrm{~PB}_{\mathrm{r} 2,50 \%}$ (isolated yield) [89]; iii. 1. $\mathrm{CH}_{2}=\mathrm{CHCH}_{2} \mathrm{MgCl}$, THF, $0{ }^{\circ} \mathrm{C}$; 2. Ti(O-iPr) ${ }_{4},(\mathrm{~L})-(+)-\mathrm{DIPT}, \mathrm{TBHP}, 3 \AA \mathrm{MS}, \mathrm{CH}_{2} \mathrm{Cl}_{2},-20{ }^{\circ} \mathrm{C}$, 97\%ee, 38\% yield over the two steps; iv. 1. $\mathrm{CH}_{2}=\mathrm{CHSiMe}{ }_{2} \mathrm{Cl}, \mathrm{Et}_{3} \mathrm{~N}, \mathrm{CH}_{2} \mathrm{Cl}_{2} ; 2$. Schrock catalyst, $\mathrm{PhH}, 87 \%$; Preparation of 78: i. $\mathrm{BnMe}_{2} \mathrm{SiC} \equiv \mathrm{CMgBr}, 57 \%$; ii. 1. $\mathrm{RuCl}(S, S) \mathrm{TsDPEN}, i \mathrm{PrOH} ; 2 . \mathrm{Ac}_{2} \mathrm{O}$ cat., DMAP, $\mathrm{Et}_{3} \mathrm{~N}, \mathrm{CH}_{2} \mathrm{Cl}_{2}, 88 \%, 97 \%$ ee; iii. $\mathrm{Pd} / \mathrm{CaCO}_{3}$, quinoline, $\mathrm{H}_{2}, \mathrm{PhMe}$-cyclohexene (10:1), $83 \%$; iv. TBAF, THF, quantitative yield.

\subsubsection{Resolvin D4}

The complete stereochemistry of RvD4 was established only in 2016 [60], and later in 2018, an organic total synthesis was reported [90], allowing multi-milligram to scale up, thus enabling commercial production of RvD4. The approach is based on assembling three building blocks, the first one consisting of C14-C22, fragment 94, with a terminal carbonyl group which reacts with the C10-C13 fragment 93 through a Wittig olefination providing, after desilylation, the cross-coupling partner 106 embodying the terminal triple bond required for the Sonogashira reaction (Scheme 14). However, the authors found 
out that iodoester C1-C9 95 was contaminated with the iodolactone 107, a secondary product resulting from intramolecular cyclisation, which could not be separated from 95 (Scheme 15). This problem was overcome by running Sonogashira reaction with the ester and lactone mixture. After reduction with $\mathrm{Zn}(\mathrm{Cu} / \mathrm{Ag})$ affording compounds 108 and 109, treatment of the mixture with potassium carbonate in methanol hydrolysed both the ester and the lactone, providing RvD4 as a single product.

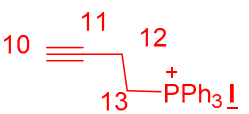

93

C10-C13 fragment

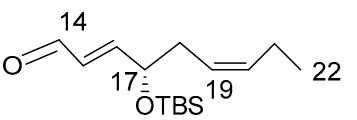

94

C14-C22 fragment<smiles>CC/C=C\[C+](O)/C=C\C=C/C=C\C=C/C=C/CC(O)C(O)CCC(C)=O</smiles><smiles>CC(C)CC#CCOC1OC(O)C(O)C1O</smiles>

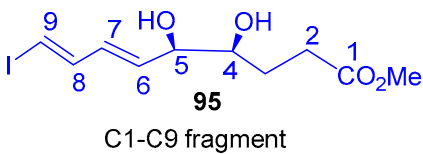

A. Synthesis of C10-C13 fragment

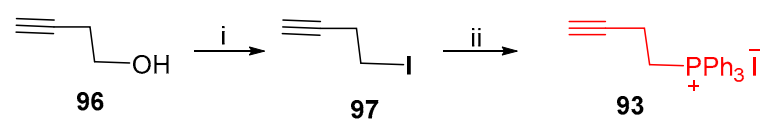

B. Synthesis of $\mathrm{C}_{14}-\mathrm{C}_{22}$ fragment

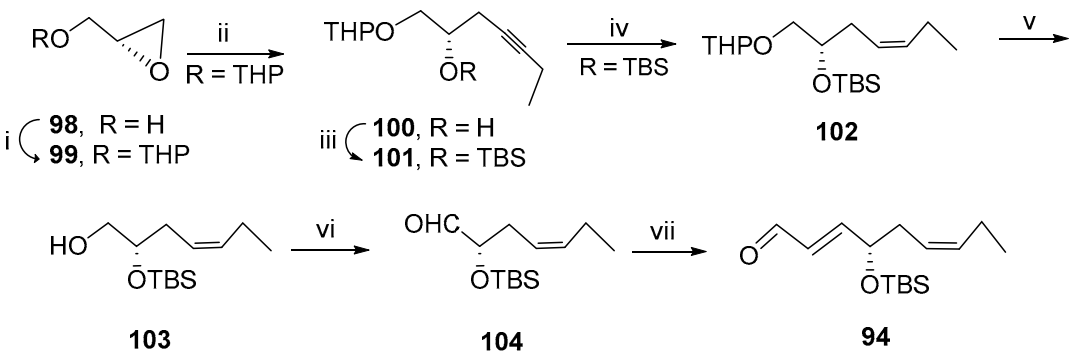

\section{Wittig reaction}

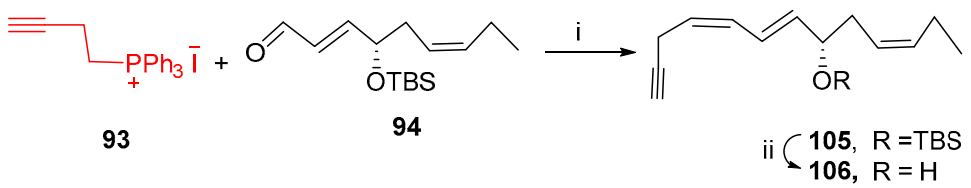

Scheme 14. Preparation of the building blocks for the synthesis of RvD4, as reported by Serhan et al. [90]. (A). Synthesis of C10-C13 fragment; (B). Preparation of C14-C22 fragment; (C). Syn-

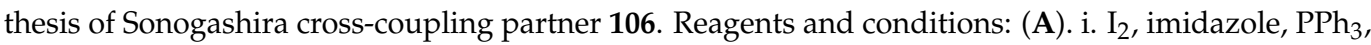
$\mathrm{CH}_{2} \mathrm{Cl}_{2}$,4h; ii. $\mathrm{PPh}_{3}, \mathrm{MeCN}$, reflux, 12 h; (B). i. cat.PTSA-H $\mathrm{H}_{2} \mathrm{O}, \mathrm{DHP}, 5$ min; ii. But-1-yne, nBuLi,

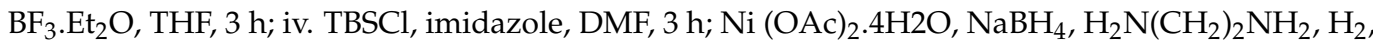
$\mathrm{EtOH}, 12$ h; v. $\mathrm{MgBr}_{2}, \mathrm{Et}_{2} \mathrm{O}, 4$ h; vi. $(\mathrm{COCl})_{2}, \mathrm{DMSO}_{3} \mathrm{Et}_{3} \mathrm{~N}, \mathrm{CH}_{2} \mathrm{Cl}_{2}, 0.5$ h; vii. $\mathrm{Ph}_{3} \mathrm{P}=\mathrm{CHCHO}, \mathrm{Net}_{3}$, $\mathrm{PhH}, 12$ h; (C). i. NaHMDS, THF, $-78^{\circ} \mathrm{C}, 3 \mathrm{~h}$; ii. TBAF, THF, $40^{\circ} \mathrm{C}, 48 \mathrm{~h}$. 

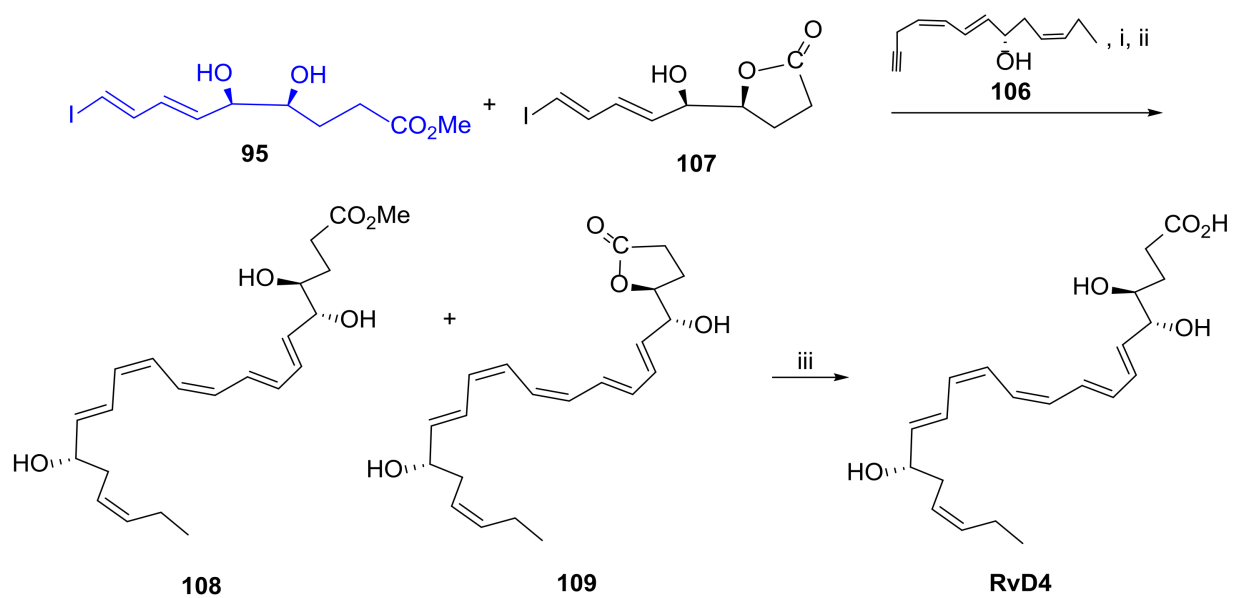

Scheme 15. Sonogashira reaction and final steps conducting to the total synthesis of RvD4, as reported by Serhan et al. [90]. Reagents and conditions: i. $\mathrm{Pd}\left(\mathrm{PPh}_{3}\right)_{4}, \mathrm{CuI}, n \mathrm{BuNH}_{2}, \mathrm{PhH}, 12 \mathrm{~h}$; ii. $\mathrm{Zn}(\mathrm{Cu} / \mathrm{Ag})$, $\mathrm{MeOH}$ (aq.), $40{ }^{\circ} \mathrm{C}, 12 \mathrm{~h}$; iii. $\mathrm{K}_{2} \mathrm{CO}_{3}, \mathrm{MeOH}, 12 \mathrm{~h}$.

\subsubsection{Resolvin D5}

The first total synthesis of RvD5 was reported by Rodríguez and Spur in 2005 [91]. The chirality centres $7(S)$ and $17(S)$ were installed via epoxide 110, obtained by hydrolytic kinetic resolution of the epoxide racemic mixture in the presence of water and $(R, R)$-salenCo (III)(Oac) (111) catalyst (Scheme 16). The preparation of the precursor of RvD5 C1-C9 moiety started by nucleophilic epoxide ring opening with the alkynide resulting from treatment of 112 with butyllithium to afford the alcohol 113, which was then protected with the benzoyl group. After cleavage of the tetrahydropyranyl group, the resulting primary alcohol 115 was oxidized with Jones reagent, and in situ esterification gave ester 116. After Lindlar reduction, the isomer embodying the cis double bond was formed in very high yield (98\%). Debenzylation with EtSH and aluminum trichloride gave the primary alcohol, the oxidation of which, followed by Takai olefination [92], afforded iodide 120, one of the reaction partners to afford the total synthesis of RvD5. The synthesis of the C15-C22 precursor 126 followed a similar strategy, starting with the reaction of epoxide 110 with the anion of but-1-yne generated with butyllithium (Scheme 17). Benzoylation of the alcohol, Lindlar reduction, debenzylation, Swern oxidation, and Takai olefination afforded a mixture of the trans / cis-vinyl iodides difficult to separate, with the trans-isomer being the major product and present in proportion 4:1. The mixture was submitted to Sonogashira reaction with iodide $\mathbf{1 2 6}$, but only the more reactive trans-vinyl alkene reacted to afford 128 in 50\% yield. After cleavage of TMS, a second Sonogashira reaction gave the methyl ester 130. Controlled hydrogenation with Lindlar catalyst, deactivated by Net $_{3}$, afforded the dibenzoyl precursor 131 in good yield (Scheme 18). Ester hydrolysis and benzoyl deprotection with the lipase Candida rugosa succeeded in 75\% yield, while attempts to use hydrolysis in mild alkaline conditions only hydrolysed the ester, and stronger basic conditions required for benzoyl deprotection led to product degradation. 

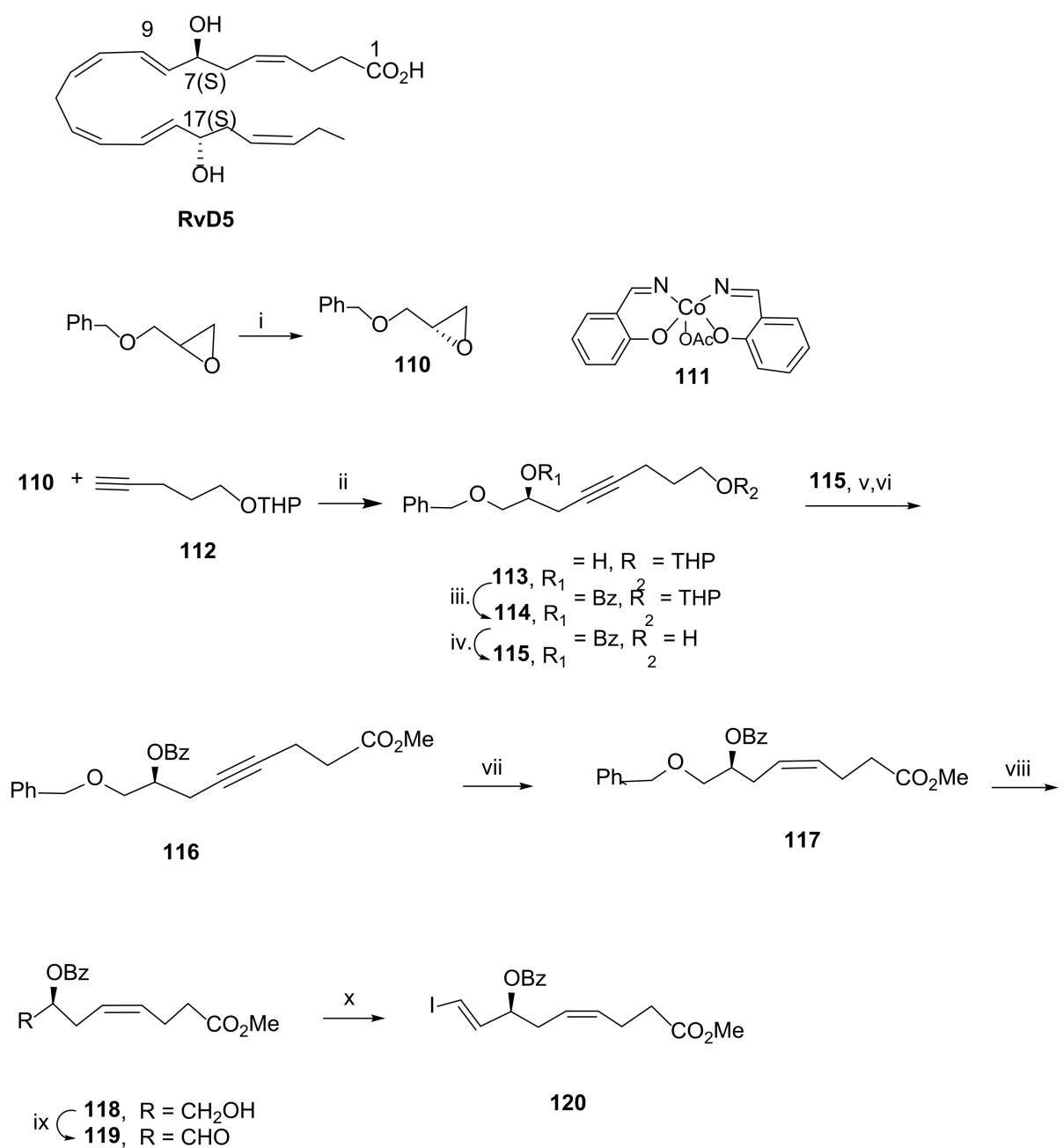

Scheme 16. Synthesis of precursor 120 for the construction of the C1-C9 moiety of RvD5 [91] Reagents and conditions: i. 111, $\mathrm{H}_{2} \mathrm{O}, 0{ }^{\circ} \mathrm{C}$ to rt, $45 \%$ yield, $>99 \%$ ee; ii. $\mathrm{nBuLi}, \mathrm{BF}_{3}$. $\mathrm{Et}_{2} \mathrm{O}, \mathrm{THF},-70$ ${ }^{\circ} \mathrm{C}, 85 \%$; iii. $\mathrm{BzCl}$ (2 equiv), $\mathrm{Py}, 0{ }^{\circ} \mathrm{C}$ to rt, $92 \%$; iv. PPTS cat., $\mathrm{MeOH}, \mathrm{rt}, 88 \%$; v. Jones reagent, acetone, $0{ }^{\circ} \mathrm{C}$; vi. $10 \% \mathrm{TMSCl}, \mathrm{MeOH}, 2$,2-dimethoxypropane, rt, $93 \%$ over the last two steps; vii. $\mathrm{H}_{2}$, Lindlar cat., hexane, $98 \%$; viii. $\mathrm{EtSH}, \mathrm{AlCl}_{3}, \mathrm{CH}_{2} \mathrm{Cl}_{2},-35{ }^{\circ} \mathrm{C}$, 86\%; ix. $\mathrm{Py}_{\mathrm{SO}}, \mathrm{DMSO}, \mathrm{CH}_{2} \mathrm{Cl}_{2}, \mathrm{Et}_{3} \mathrm{~N}, 86 \%$; x. $\mathrm{CrCl}_{2}, \mathrm{CHI}_{3}, \mathrm{THF}, \mathrm{rt}, 52 \%$.

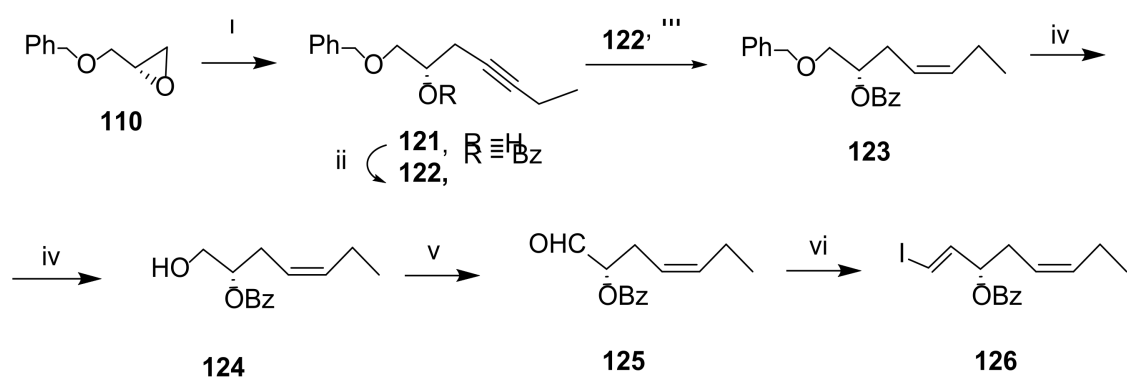

Scheme 17. Preparation of precursor 126 for the construction of the C15-C22 moiety of RvD5 [91]. Reagents and conditions: i. $\mathrm{HC} \equiv \mathrm{CCH}_{2} \mathrm{CH}_{3}, n \mathrm{BuLi}, \mathrm{BF}_{3} \cdot \mathrm{Et}_{2} \mathrm{O}, \mathrm{THF},-70{ }^{\circ} \mathrm{C}, 80 \%$; ii. $\mathrm{BzCl}$ (2 equiv), Py, $0{ }^{\circ} \mathrm{C}$ to rt, $94 \%$; iii. $\mathrm{H}_{2}$, Lindlar cat., hexane, $96 \%$; iv. $\mathrm{EtSH}, \mathrm{AlCl}_{3}, \mathrm{CH}_{2} \mathrm{Cl}_{2},-35{ }^{\circ} \mathrm{C}, 85 \%$; v. $\mathrm{Py}^{-} \mathrm{SO}_{3}$, DMSO, $\mathrm{CH}_{2} \mathrm{Cl}_{2}, \mathrm{Et}_{3} \mathrm{~N}, 84 \%$; vi. $\mathrm{CrCl}_{2}, \mathrm{CHI}_{3}, \mathrm{THF}$, rt, trans-vinyl iodide/cis-vinyl iodide (4:1). 


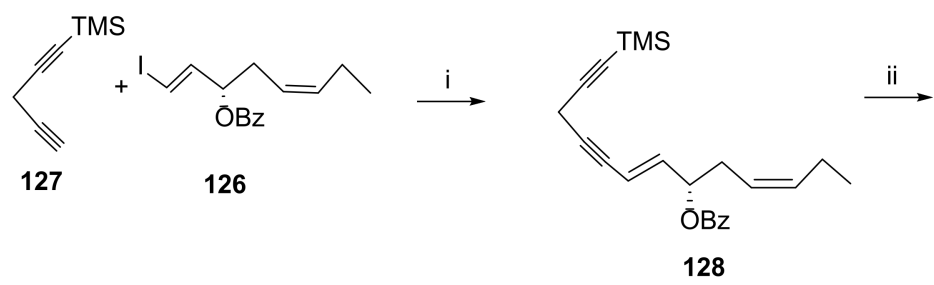

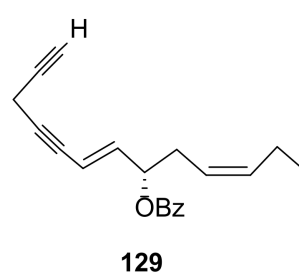

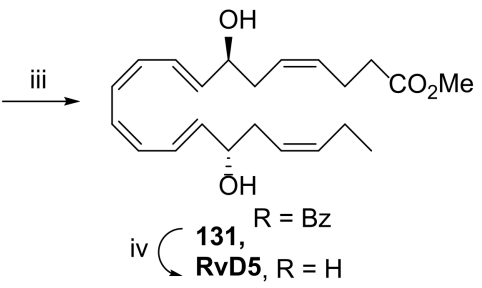

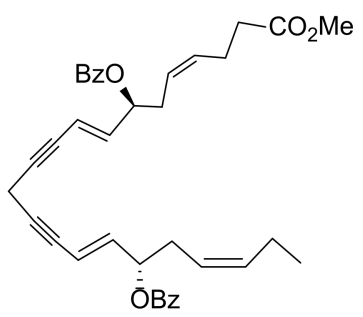

130

Scheme 18. First total synthesis of RvD5 [91]. Reagents and conditions: i. $\mathrm{Pd}\left(\mathrm{PPh}_{3}\right)_{4}, \mathrm{CuI}, \mathrm{PrNH}_{2}$, benzene, rt, 50\% (128), 54\% (130); ii. $\mathrm{AgNO}_{3}, \mathrm{MeOH}, \mathrm{H}_{2} \mathrm{O}, \mathrm{NaCN}$; iii. $\mathrm{H}_{2}$, Lindlar cat., $\mathrm{Et}_{3} \mathrm{~N}$, hexane, $84 \%$; iv. Lipase from Candida rugosa, $\mathrm{H}_{2} \mathrm{O}\left(\mathrm{CaCl}_{2}, \mathrm{NaCl}\right), \mathrm{THF}, 75 \%$.

In 2017, Kobayashi and co-workers [93] developed a new approach for the synthesis of RvD5 by assembling the key building blocks via Wittig reaction-namely, the C14-C22 aldehyde synthon 133, which reacted with the C11-C13 phosphonium salt that, after deprotection of TBS, afforded the C11-C22 alcohol 136, which was transformed in the iodide 137. Reaction with triphenylphosphane afforded phosphonium salt 138, the Wittig reaction of which with the C1-C10 aldehyde $\mathbf{1 3 5}$ gave RvD5 fully protected precursor 139 (Scheme 19). Selective TBS deprotection of the primary functionality with PPTS in methanol was followed by oxidation to carboxylic acid and esterification by reaction with diazomethane. Treatment with TBAF gave the ester $\mathbf{1 4 1}$ with the free hydroxy groups at positions 7 and 17, the hydrolysis of which with lithium hydroxide afforded RvD5 in 5.6\% overall yield from aldehyde $\mathbf{1 3 3}$. The synthesis of synthon 133 (Scheme 20A) started from commercially available 3-(trimethylsilyl) prop-2-yn-1-ol 142. Reduction with lithium aluminium hydride to install the double bond, oxidation of the primary alcohol to aldehyde with pyridinium chlorochromate (PCC), and aldol reaction conducted to the preparation of ester $\mathbf{1 4 3}$ in $69 \%$ yield over the three steps. After protecting the hydroxy group with the tert-butyldimethylsilyl(TBS) group, DIBAL reduction generated the terminal aldehyde, the Wittig reaction of which with the ylide resulting from basic treatment of the triphenyl(propyl)phosphonium bromide, followed by TBS cleavage, gave racemic alcohol 146 in $74 \%$ yield over the three steps. Sharpless regio- and stereoselective epoxidation afforded epoxide 147 in $47 \%$ isolated yield. After protection of the hydroxy group with TBS, the nitrile was installed by reaction with diethylaluminum cyanide via epoxide ring opening and Peterson olefination to give 148. Nitrile reduction with DIBAL afforded the aldehyde $\mathbf{1 3 3}$, isolated in $73 \%$ yield.

The synthon 135 was prepared starting from compound 144 (Scheme 20B). Reduction with DIBAL to generate aldehyde $\mathbf{1 4 5}$ was followed by Wittig olefination, giving the cis-alkene 149, desilylated with TBAF to afford diol 150 in $91 \%$ yield over the three steps. Regioselective protection of the primary alcohol with the TBS group was followed by Sharpless asymmetric epoxidation, giving compound $\mathbf{1 5 2}$ in high enantiomeric excess and $44 \%$ yield. Reaction with diethylaluminum cyanide afforded nitrile 155 in very high 
yield, which was finally reduced with DIBAL, giving the aldehyde synthon 135 , isolated in $82 \%$ yield.

In Figure 3, a summary of both the methodologies here reviewed for the total synthesis of RvD5 is given, indicating the number of steps required, the key reactions for assembling the building blocks, and the yields and number of steps required for the preparation of the building blocks. Both approaches are, indeed, strategic, very elegant, and successful, involving stereo- and regioselective reaction steps culminating in the total synthesis of RvD5, a complex structure with multiple cis- and trans-double bonds and two chirality centres with (S)-configuration.

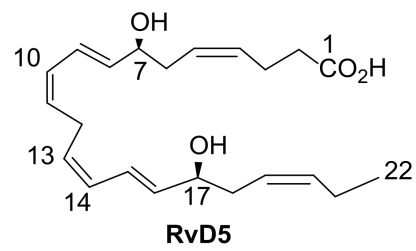

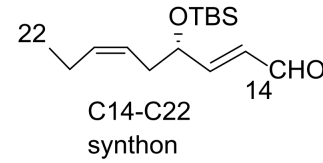

133

$$
\overbrace{\substack{\mathrm{C} 11-\mathrm{C} 13 \\ \text { synthon }}}^{+} \overline{\mathrm{Br}}
$$

134

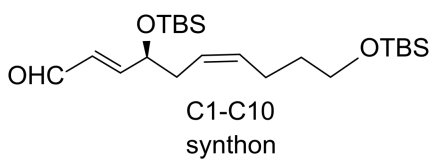

135

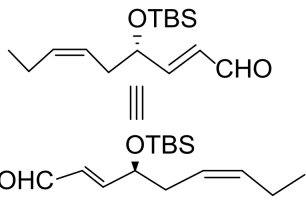

133
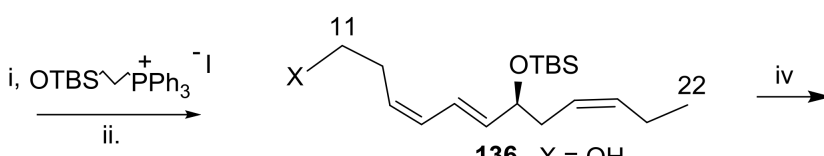

iii $136, x=\mathrm{OH}$

137, $X=1$

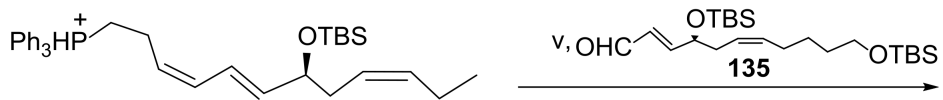

138

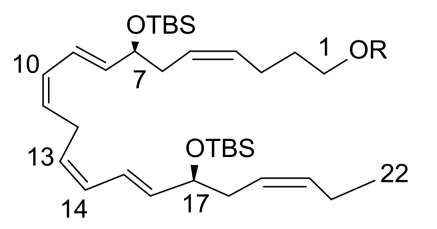

140, vii, viii, ix, $x$

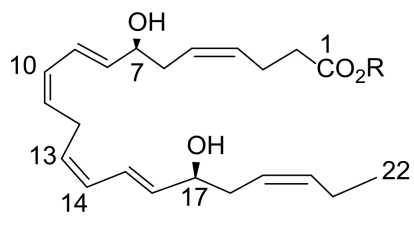

$$
\text { vi }\left(\begin{array}{l}
139, \mathrm{R}=\mathrm{TBS} \\
140, \mathrm{R}=\mathrm{H}
\end{array}\right.
$$

$$
x i\left(\begin{array}{l}
141, R=M e \\
R v D 5, R=H
\end{array}\right.
$$

Scheme 19. Synthesis of RvD5, as reported by Kobayashi and co-workers [93]. Reagents and conditions: i. NaHMDS, THF, $-70{ }^{\circ} \mathrm{C}, 8 \mathrm{~h}$; ii. PPTS, $\mathrm{MeOH}, \mathrm{rt}, 77 \%$ over the two steps; iii. $\mathrm{I}_{2}, \mathrm{Ph}_{3} \mathrm{P}$, imidazole, $85 \%$; iv. $\mathrm{Ph}_{3} \mathrm{P}, \mathrm{MeCN}$, quant.; v. NaHMDS, $-90{ }^{\circ} \mathrm{C}$ to $0{ }^{\circ} \mathrm{C}$; vi. PPTS, $\mathrm{MeOH}, 53 \%$ over the two steps; vii. PCC; viii. $\mathrm{NaClO}_{2}, 81 \%$ over the two steps; ix. $\mathrm{CH}_{2} \mathrm{~N}_{2}$; $\mathrm{x}$. TBAF, $44 \%$ over the two steps, xi. $\mathrm{LiOH}, \mathrm{THF}, \mathrm{MeOH}, \mathrm{H}_{2} \mathrm{O}, 45 \%$. 
A. Preparation of C14-C22 synthon

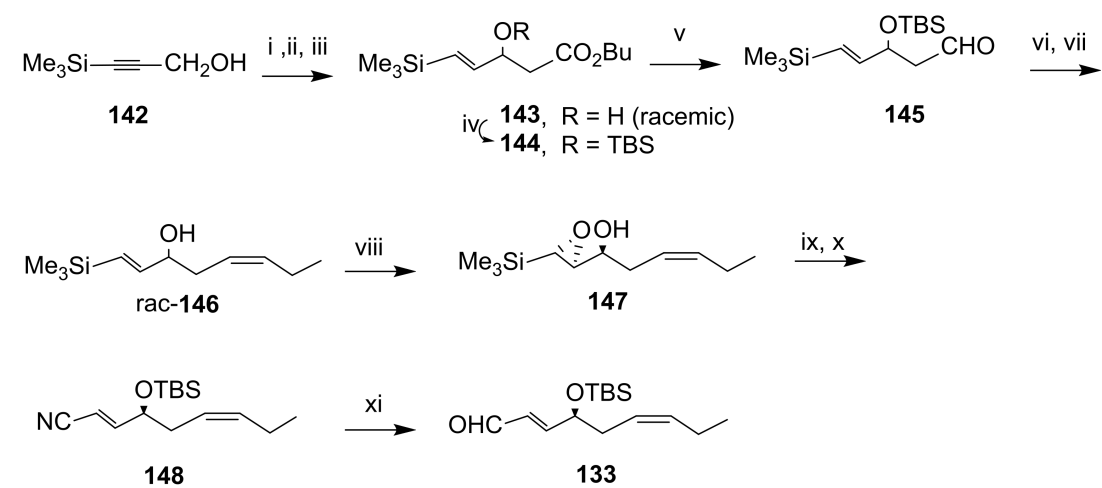

B. Preparation of C1-C10 synthon

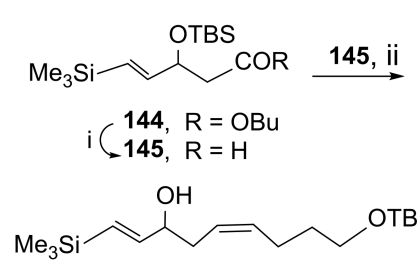

rac-151

$$
\mathrm{Me}_{3} \mathrm{Si} \overbrace{=\mathrm{TBS}, \mathrm{R}=\mathrm{TBDPS}}^{\mathrm{OR}_{1}}
$$$$
\text { iii }\left(\begin{array}{cc}
149, & R_{1}=R=H^{2} \\
150 & R_{1}
\end{array}\right.
$$<smiles>N#CC1CCCCC1</smiles>

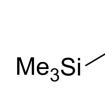<smiles>[R]O[C@H](CC)[C@@H]1CC[C@H](C)O1</smiles><smiles>C#CCCCC</smiles>
OTBS 153, vii<smiles>CC#C[SbH2]OCCC/C=C/C[C@@H]([OH2+])/C=C/C#N</smiles>

155

135

Scheme 20. Preparation of C14-C22 synthon 133 (A) and C1-C10 synthon 135 (B). Reagents and conditions: (A). i. $\mathrm{LiAlH}_{4}$; ii. PCC; iii. MeCOOBu/LDA, $69 \%$ over the three steps; iv. TBSCl, imidazole, $89 \%$; v. DIBAL; vi. $\mathrm{PrPPh}_{3} \mathrm{Br}$, NaHMDS, THF, $-90^{\circ} \mathrm{C}$ to rt, $12 \mathrm{~h}$, vii. TBAF, $74 \%$ over the three steps; viii. $\mathrm{BuOOH}, \mathrm{Ti}(\mathrm{OiPr})_{4}, \mathrm{~L}-(+)-\mathrm{DIPT}, \mathrm{CH}_{2} \mathrm{Cl}_{2},-18{ }^{\circ} \mathrm{C}, 6 \mathrm{~h}, 47 \%, 98 \%$ ee; ix. TBSOTf, 2,6-lutidine, $\mathrm{CH}_{2} \mathrm{Cl}_{2}$, rt, $1.5 \mathrm{~h} ; \mathrm{x}$. Et ${ }_{2} \mathrm{AlCN}$, toluene, rt, overnight, $79 \%$ over the two steps; xi. DIBAL, $\mathrm{CH}_{2} \mathrm{Cl}_{2},-40{ }^{\circ} \mathrm{C}$ to $0{ }^{\circ} \mathrm{C}, 1 \mathrm{~h}, 73 \%$. (B). i. DIBAL, $-78{ }^{\circ} \mathrm{C}$; ii. TBDPSO $\left(\mathrm{CH}_{2}\right)_{4} \mathrm{PPh}_{3} \mathrm{I}, \mathrm{NaHMDS}$, $\mathrm{THF},-90{ }^{\circ} \mathrm{C}$ to $\mathrm{rt}, 14 \mathrm{~h}$; iii. TBAF, 91\% from 144; iv. $\mathrm{TBSCl}, \mathrm{CH}_{2} \mathrm{Cl}_{2}, 0{ }^{\circ} \mathrm{C}, 3.5 \mathrm{~h}, 84 \%$; v. $t \mathrm{BuOOH}$, L-(+)-DIPT, $\mathrm{Ti}(\mathrm{O} i \mathrm{Pr})_{4}, \mathrm{CH}_{2} \mathrm{Cl}_{2},-18{ }^{\circ} \mathrm{C}, 6 \mathrm{~h}, 44 \%$ and $98 \%$ ee; vi. TBSOTf, 2,6-lutidine, $\mathrm{CH}_{2} \mathrm{Cl}_{2}, \mathrm{rt}, 3 \mathrm{~h}$; vii. $\mathrm{Et}_{2} \mathrm{AlCN}$, toluene, $0{ }^{\circ} \mathrm{C}, 2 \mathrm{~h}, 92 \%$ over the two steps; viii. DIBAL, $\mathrm{CH}_{2} \mathrm{Cl}_{2},-70{ }^{\circ} \mathrm{C}, 1 \mathrm{~h}, 82 \%$.

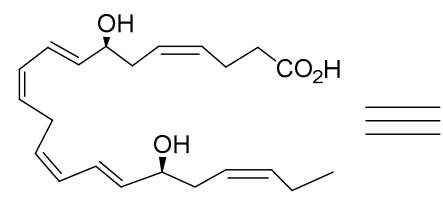

Key reaction: Wittig olefination Total number of steps: 30 Key precursors' overall yield: ca. $12 \%$ for 133 ( 11 steps) ca. $25 \%$ for 135 ( 8 steps)

Starting material: $\mathrm{Me}_{3} \mathrm{Si}=-\mathrm{CH}_{2} \mathrm{OH}$

Overall yield of Wittig reaction pathway and deprotections: $6 \%$ (11 steps)<smiles>C/C=C\CC(O)/C=C/C=C/CC(=O)O</smiles>

Key reaction: Sonogashira reaction Total number of steps: 21

Key precursors' overall yield: ca. $11 \%$ for $\mathbf{1 2 0}$ (10 steps) ca. $19 \%$ for $\mathbf{1 2 6}$ (6 steps)

Starting material:<smiles>c1ccc(OCC2CO2)cc1</smiles>

Overall yield of Sonogashira reaction pathway and deprotections: 17\% (5 steps)

Figure 3. Summary of the total synthesis steps and overall yields of RvD5 [91,93]. 


\subsubsection{Resolvin D6}

In 2012, the first total synthesis of RvD6 was reported by Rodríguez and Spur [94]. Sonogashira coupling was the key reaction to assemble the core structure of RvD6, and the key precursors are compounds 156, furnishing the triple bond and iododerivatives 157 and 158 (Scheme 21). The first Sonogashira reaction coupled 156 with the iodide 157 under $\mathrm{Pd}(0) / \mathrm{CuI}$ catalysis to give the intermediate 159 . Cleavage of the trimethylsilyl group by treatment with sodium nitrate, followed by sodium cyanide work-up gave alkyne $\mathbf{1 6 0}$, which was coupled with the iodoester $\mathbf{1 5 8}$ through the second Sonogashira reaction. After TBS deprotection, $\mathrm{Zn}(\mathrm{Cu} / \mathrm{Ag})$ reduction of $\mathbf{1 6 2}$ afforded 163 embodying the core structure of RvD6, which was obtained after mild alkaline ester hydrolysis.

\section{Total synthesis of RvD6}
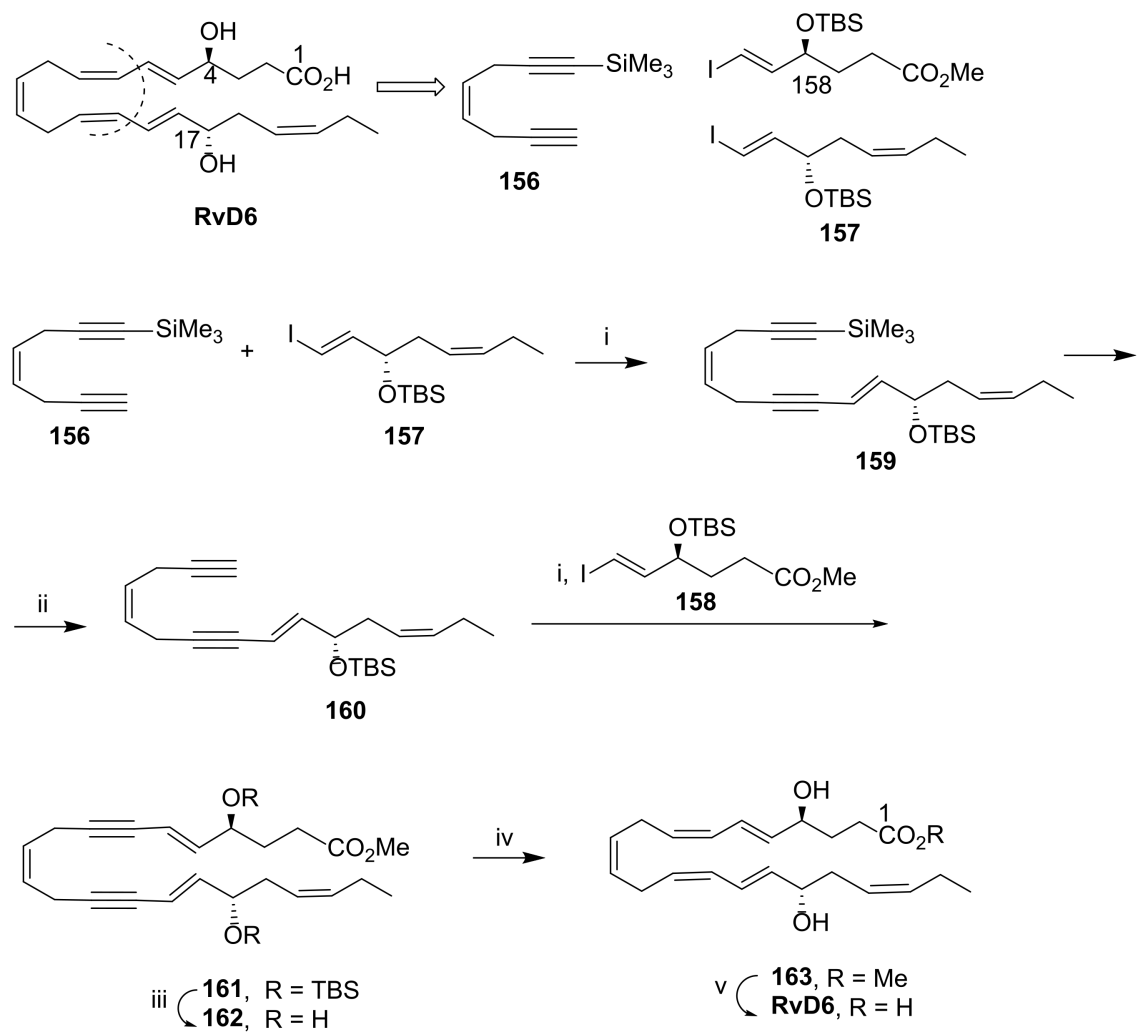

Scheme 21. Total synthesis of RvD6, as reported by Rodríguez and Spur [94]. Reagents and conditions: i. $\mathrm{Pd}\left(\mathrm{PPh}_{3}\right)_{4}, \mathrm{CuI}, \mathrm{PrNH}_{2}$, benzene, rt; ii. $\mathrm{AgNO}_{3}, \mathrm{CH}_{3} \mathrm{OH}, \mathrm{H}_{2} \mathrm{O}, \mathrm{NaCN},{ }^{\circ} \mathrm{C}$; iii. $\mathrm{MeCOCl}, \mathrm{CH}_{3} \mathrm{OH}$, $0{ }^{\circ} \mathrm{C}$ to rt; iv. $\mathrm{Zn}(\mathrm{Cu} / \mathrm{Ag}), \mathrm{CH}_{3} \mathrm{OH}, \mathrm{H}_{2} \mathrm{O}, 50^{\circ} \mathrm{C}$; v. $1 \mathrm{~N} \mathrm{LiOH}, \mathrm{H}_{2} \mathrm{O}, \mathrm{THF}, 0^{\circ} \mathrm{C}$, then $\mathrm{H}^{+}\left(\mathrm{NaH}_{2} \mathrm{PO}_{4}\right.$ saturated) (yields were not provided).

As the key precursors are not commercially available, their preparation has been accomplished. The key precursor 156 was synthesized starting from 1,4-dibromobut-2-ene (164) in two steps (Scheme 22A). Treatment with trimethylsilylacetylene excess (165) in DMF at room temperature gave 166 in 34\% isolated yield, which was desilylated with silver nitrate (2 equiv) and work-up with sodium cyanide, providing 156 by extraction with hexane/ethyl acetate. The configuration of the chirality centre at RvD6 C17 was introduced in precursor $\mathbf{1 5 7}$ via Sharpless asymmetric epoxidation (Scheme 22B). Its synthesis started with the reaction of propargyl alcohol 167 with 1-bromopent-2-yne (168) to provide octa-2,5-diyn-1-ol (169). Triple bond reduction with lithium aluminum hydride was regioselective affording the enynol $\mathbf{1 7 0}$ in $70 \%$ yield. Stereoselective Sharpless epoxidation gave 171, and Lindlar reduction of the triple bond installed the cis-double bond present in $\mathbf{1 7 2}$ Replacement of the hydroxy group by iodide gave epoxide 173, which was transformed into the alcohol 174 with the required configuration by elimination with NaHDMS and 
concomitant epoxide ring opening. Hydroxy group protection with TBS provided the key precursor 157 in $67 \%$ yield.

A.
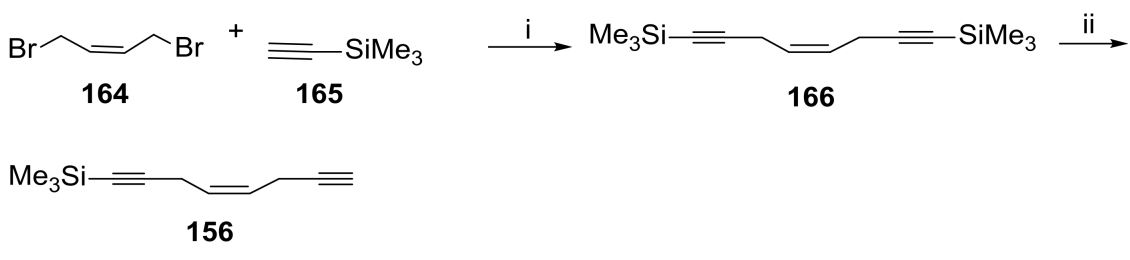

B.
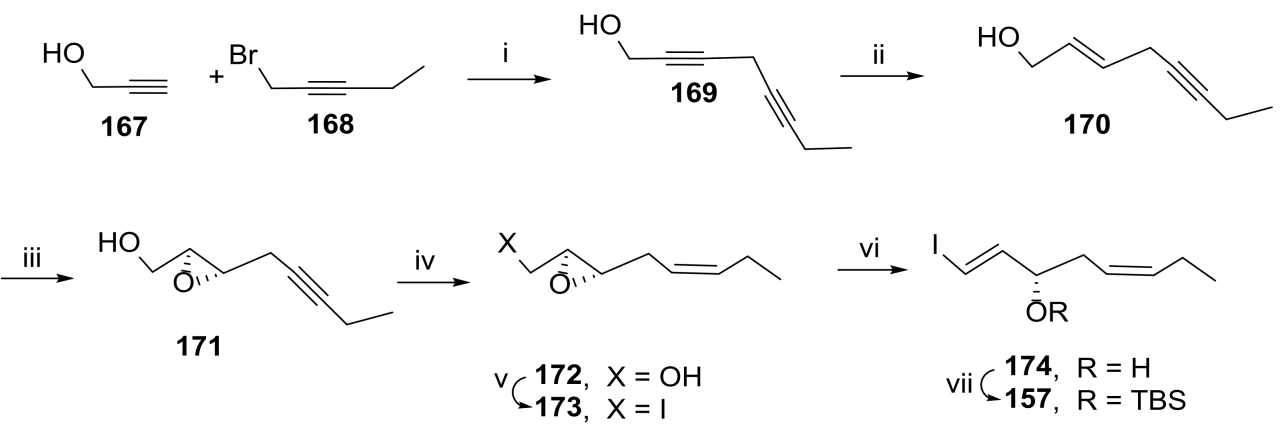

C.
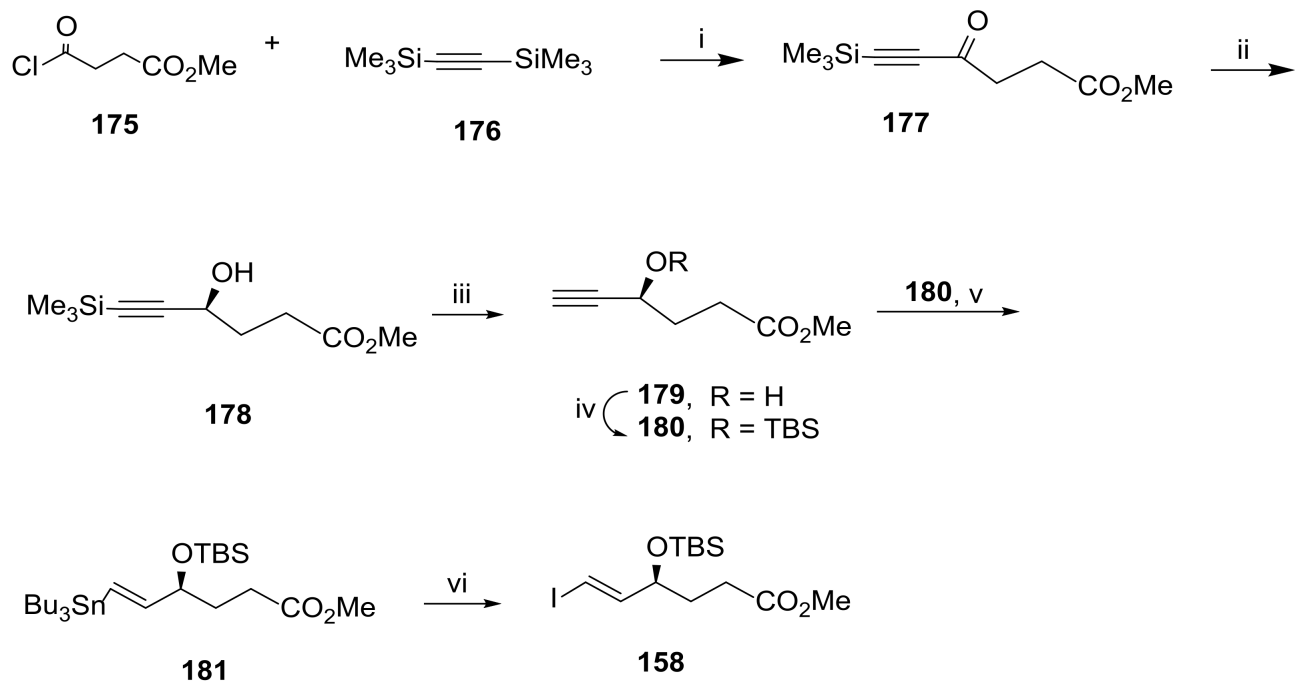

Scheme 22. Synthesis of Sonogashira coupling partners, as reported by Rodríguez and Spur [94]. (A). i. CuI, $\mathrm{Na}_{2} \mathrm{SO}_{3}, \mathrm{~K}_{2} \mathrm{CO}_{3}, \mathrm{DMF}$, rt; ii. $\mathrm{AgNO}_{3}, \mathrm{CH}_{3} \mathrm{OH}, \mathrm{H}_{2} \mathrm{O}, \mathrm{NaCN}, 0{ }^{\circ} \mathrm{C}$; (B). i. DBU, CuI, HMPA, THF; ii. $\mathrm{LiAlH}_{4}$, ether, $0{ }^{\circ} \mathrm{C}$ to rt; iii. L-(+)-DMT, Ti(OiPr) ${ }_{4}, \mathrm{TBHP}$, molecular sieves $4 \AA$, $\mathrm{CH}_{2} \mathrm{Cl}_{2}$; iv. $\mathrm{H}_{2}$, Lindlar cat., $\mathrm{Et}_{3} \mathrm{~N}$, hexane; v. $\mathrm{I}_{2}, \mathrm{Ph}_{3} \mathrm{P}$, imidazole, $i \mathrm{Pr}_{2} \mathrm{EtN}, \mathrm{CH}_{3} \mathrm{CN}$, ether; vi. NaHMDS, DMF, $-60{ }^{\circ} \mathrm{C}$; vii. TBSCl, imidazole, DMF, $67 \%$; (C). i. $10 \% \mathrm{InBr}_{3}, \mathrm{CH}_{2} \mathrm{Cl}_{2}, 0{ }^{\circ} \mathrm{C}$ to rt, $94 \%$; ii. $\mathrm{Ru}[(S, S)-\mathrm{TsDPEN}]\left(p\right.$-cymene), $i \mathrm{PrOH}$, rt; iii. KF.2 $\mathrm{H}_{2} \mathrm{O}, 18$-crown-6, DMF, rt; iv. TBSCl, imidazole, $\mathrm{DMF}, 0{ }^{\circ} \mathrm{C}$ to $\mathrm{rt}, 63 \%$ over the three steps; v. $\mathrm{Bu}_{3} \mathrm{SnH}, \mathrm{AIBN}, 130{ }^{\circ} \mathrm{C}$; vi. $\mathrm{I}_{2}$, ether, $0{ }^{\circ} \mathrm{C}, 93 \%$.

The preparation of $\mathbf{1 5 8}$ was accomplished starting with reaction of methyl 4-chloro4-oxobutanoate (175) with bis(trimethylsilyl)acetylene catalysed by indium bromide, affording the alkinyl derivative 177 in 94\% yield (Scheme 22C). The key reaction to install the configuration of the chirality centre at RvD6 C4 is the asymmetric transfer hydrogenation, producing the chiral intermediate 178 with more than $95 \%$ enantiomeric excess. After desilylation with potassium fluoride in the presence of catalytic crown ether and TBS protection of the hydroxy group to give 180, free radical addition with excess tributyltin 
hydride in the presence of catalytic amount of azobisisobutyronitrile gave $\mathbf{1 8 1}$ in moderate yield. Reaction with iodine afforded the key precursor 158 in 93\% yield.

Kobayashi and co-workers [95] have recently reported another approach for the total synthesis of RvD6, by using intermediates 182, 183, and 184 (Scheme 23), envisioning a strategy based on Sonogashira coupling of 183 and 184 to 182, followed by hydrogenation with experimental conditions, affording the required double bonds (Scheme 24).

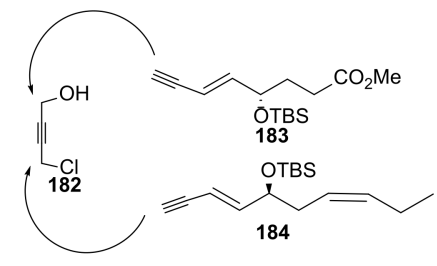

A. Synthesis of intermediate 183

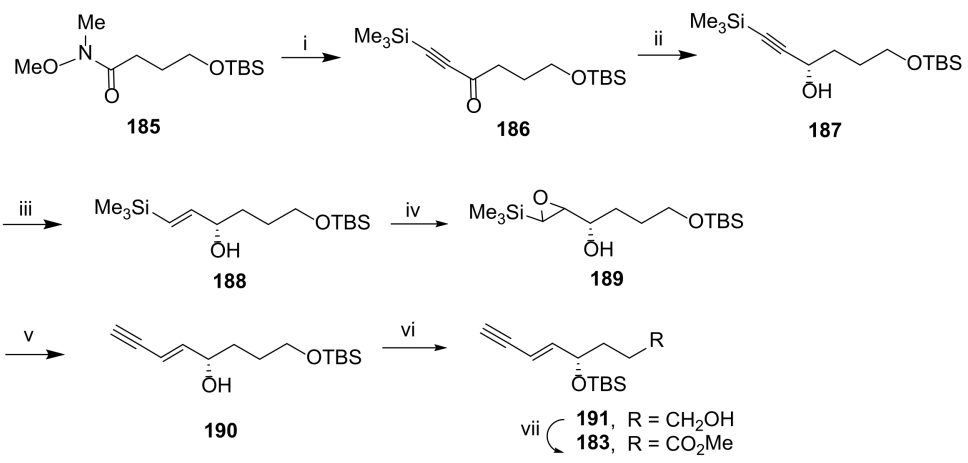

B. Synthesis of intermediate 184

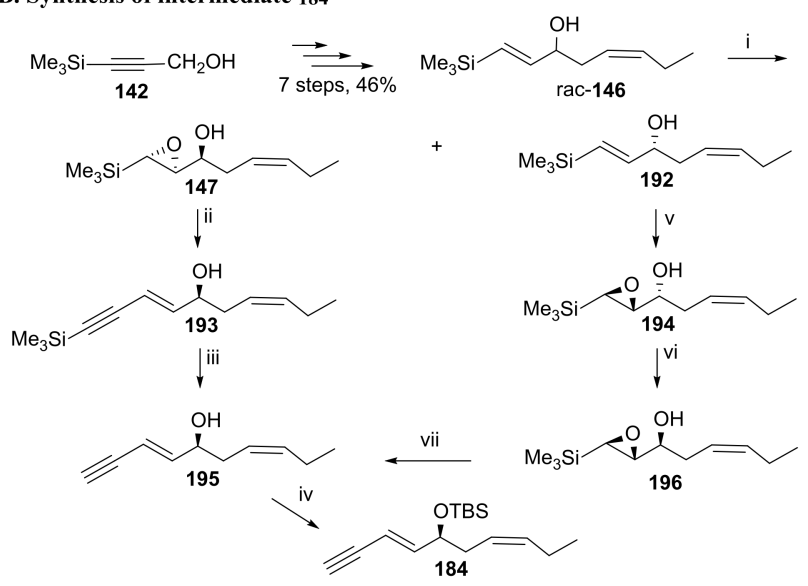

Scheme 23. Strategy for the synthesis of RvD6 and preparation of the intermediates $\mathbf{1 8 3}$ and 184, as reported by Kobayashi and co-workers [95]. Reagents and conditions: (A). i.Me $\mathrm{Me}_{3} \mathrm{Si}-\mathrm{C} \equiv \mathrm{C}-\mathrm{Li}$ (1.7 equiv.), THF, $-78{ }^{\circ} \mathrm{C}$ to $0{ }^{\circ} \mathrm{C}, 99 \%$; ii. $\mathrm{Ru}[(\mathrm{S}, S)$-TsDPEN] ( $p$-cymene), $i \operatorname{PrOH}, \mathrm{rt}, 1 \mathrm{~h}, 96 \%$ yield and $98 \%$ ee; iii. Red-Al, $\mathrm{Et}_{2} \mathrm{O}, \mathrm{rt}, 4$ h, 59\%; iv. $m$-CPBA, $\mathrm{NaHCO}_{3}, \mathrm{rt}, 71 \%$, syn/anti 3:2; v. $1 . \mathrm{Me}_{3} \mathrm{Si}-\mathrm{C} \equiv \mathrm{C}-\mathrm{Li}$ (8 equiv.), THF, HMPA, rt, 5 h; $2 . \mathrm{K}_{2} \mathrm{CO}_{3}$ ( 5 equiv.), $\mathrm{MeOH}, \mathrm{rt}, 2 \mathrm{~h}, 42 \%$ (2 steps); vi. $1 . \mathrm{TBSCl}$, imidazole, $92 \%$; 2. PPTS (cat.), $\mathrm{CH}_{2} \mathrm{Cl}_{2}, \mathrm{MeOH}, \mathrm{rt}, 4 \mathrm{~h}, 55 \%$ [recovered bis (TBS ether), 33\%]; vii. 1 . $(\mathrm{COCl})_{2}, \mathrm{DMSO}, \mathrm{Et}_{3} \mathrm{~N} ; 2 . \mathrm{NaClO}_{2}, \mathrm{Me}_{2} \mathrm{C}=\mathrm{CHMe} ; 3 . \mathrm{CH}_{2} \mathrm{~N}_{2}, 51 \%$ from 191. (B). i. $\mathrm{tBuOOH}$, $\mathrm{Ti}(\mathrm{OiPr})_{4}, \mathrm{~L}-(+)-\mathrm{DIPT}, 47 \%$ (147, 99\% ee) and $42 \%$ (192, 99\% ee); ii. $\mathrm{Me}_{3} \mathrm{Si}-\mathrm{C} \equiv \mathrm{C}-\mathrm{Li}$ (6 equiv.), THF, $\mathrm{HMPA}, \mathrm{rt}, 6 \mathrm{~h}$; iii. $\mathrm{K}_{2} \mathrm{CO}_{3}$ (1.2 equiv.), $\mathrm{MeOH}, \mathrm{rt}, 3 \mathrm{~h}, 78 \%$ (over two steps); iv. TBSCl, imidazole, $89 \%$; v. $t \mathrm{BuOOH}$, $\mathrm{Ti}(\mathrm{OiPr})_{4}$, D-(-)-DIPT, $\mathrm{CH}_{2} \mathrm{Cl}_{2},-18^{\circ} \mathrm{C}, 6$ h, $89 \%$; vi. 1. $4-\left(\mathrm{NO}_{2}\right) \mathrm{C}_{6} \mathrm{H}_{4} \mathrm{CO}_{2} \mathrm{H}, \mathrm{PPh}_{3}$, DIAD; $2.2 \mathrm{~N} \mathrm{NaOH}$ aq., $85 \%$; vii. 1 . $\mathrm{Me}_{3} \mathrm{Si}-\mathrm{C} \equiv \mathrm{C}-\mathrm{Li}$ (4 equiv.), THF, $\mathrm{HMPA}, \mathrm{rt}, 4$ h; $2 . \mathrm{K}_{2} \mathrm{CO}_{3}, \mathrm{MeOH}$, $78 \%$ from 196. 


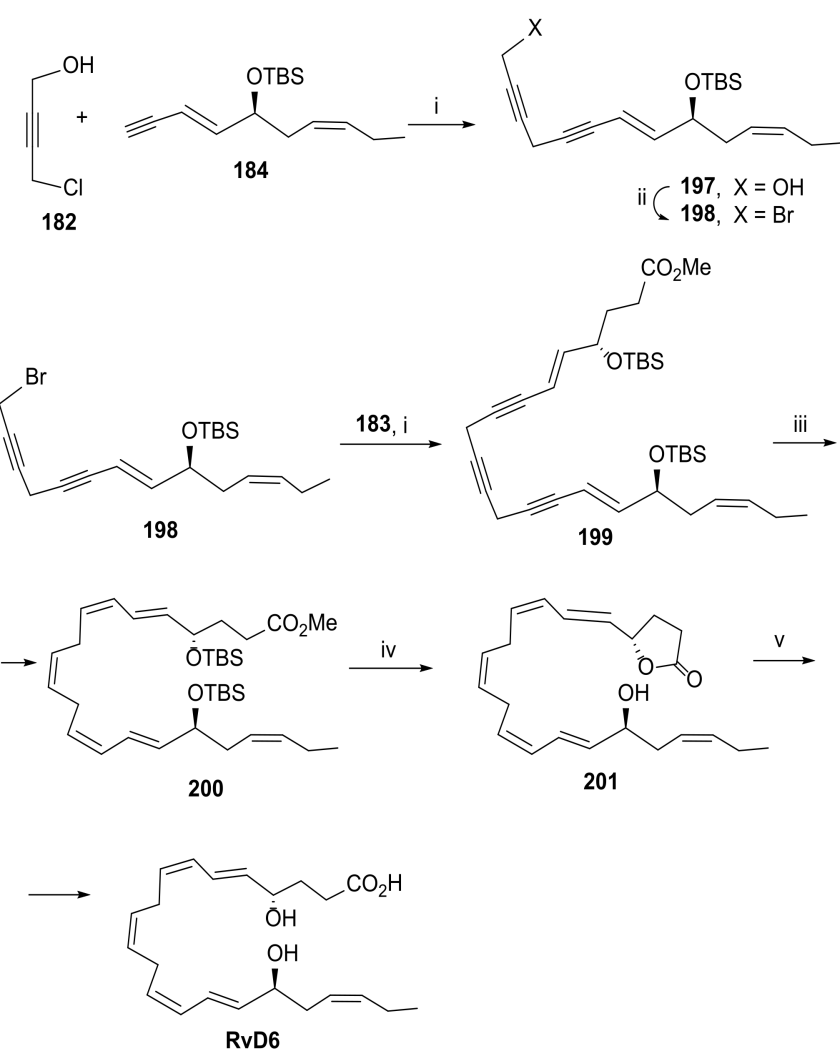

Scheme 24. Synthesis of RvD6, as reported by Kobayashi and co-workers [95]. Reagents and conditions: i. $\mathrm{NaI}$ (2 equiv.), $\mathrm{CuI}$ (2 equiv.), $\mathrm{CsCO}_{3}$ (1.4 equiv.), DMF, rt, 22h for 197 and $7 \mathrm{~h}$ for 199, 82\%; ii. $\mathrm{CBr}_{4}, \mathrm{PPh}_{3}, 73 \%$ for 198 over the two steps; iii. $\mathrm{Zn}(\mathrm{Cu} / \mathrm{Ag})\left(1600\right.$ equiv.), $\mathrm{MeOH} / \mathrm{H}_{2} \mathrm{O}, 40{ }^{\circ} \mathrm{C}, 37 \mathrm{~h}$, $76 \%$; iv. TBAF (8 equiv.), THF, rt, 1 h, 53\%; v. $\mathrm{LiOH} \cdot \mathrm{H}_{2} \mathrm{O}$ (2 equiv.), $\mathrm{MeOH} / \mathrm{THF} / \mathrm{H}_{2} \mathrm{O}, \mathrm{rt}, 1 \mathrm{~h}, 79 \%$.

The preparation of 183 was accomplished starting from amide 185, synthesized from butyrolactone [96]. After reaction with trimethylsilylacetylide for the introduction of the triple bond and stereoselective reduction of the carbonyl group with the Noyori catalyst [97], reduction with Red-Al provided the hex-1-en-3-ol derivative 188. Epoxidation was followed by reaction with the lithium trimethylsilylacetylide and trimethylsilyl desilylation to afford alcohol 190 containing the $(E)$-enyne moiety. Protection of the hydroxy group with TBSCl and regioselective deprotection of the primary position gave 191. Intermediate 183 was achieved by Swern oxidation of 191 to carboxylic acid and esterification. The overall yield for the formation of this intermediate was $4.3 \%$ from amide $\mathbf{1 8 5}$.

The synthesis of intermediate 184 started from the racemic allylic alcohol 146 (Scheme 23B), obtained in 46\% yield overall yield (seven steps) from 3-trimethylsilylprop2-yn-1-ol and already applied for the preparation of RvD5 (Scheme 20). Asymmetric epoxidation gave epoxide 147 and the allylic alcohol 192, both used for the synthesis of 184 . The epoxide reacted with lithium trimethylsilylacetylide to afford alcohol 193, which was desilylated and then protected with the group TBS. This synthetic pathway provided 184 with the overall yield of 15\% from 3-trimethylsilylprop-2-yn-1-ol (142), involving eleven steps. The alternative pathway started from allylic alcohol 192, which was converted to 194, the enantioner of 147, by Sharpless asymmetric epoxidation. Inversion of the configuration of the centre of chirality linked to the hydroxy group was achieved by Mitsunobu reaction, affording 196 in high yield. Reaction with lithium acetylide at room temperature was completed in four hours, giving alcohol 195, the hydroxy group of which was then protected with TBS by reaction with TBSCl in the presence of imidazole. The overall yield of this route was $10 \%$, covering twelve steps. Sonogashira coupling was a key reaction to access RvD6 core structure. The coupling of chloropropynol 182 and the triple bond containing partner 184 afforded 197, which was transformed in the bromoester 198 by treatment with 
tetrabromomethane and triphenylphosphane. A second Sonogashira coupling of 198 with reaction partner 183 gave precursor 199 in $82 \%$ yield. The next key reaction is the reduction of the triple bonds, achieved with $\mathrm{Zn}(\mathrm{Ag} / \mathrm{Cu})$ in high excess (1600 equivalent) for the reduction of the non-conjugated triple bond, installing RvD6 core structure in compound 200. Treatment with tert-butylammonium fluoride led to desilylation and to an intramolecular cyclization with the formation of a butyrolactone, the hydrolysis of which with lithium hydroxide hydrate afforded RvD6 (Scheme 24), in an overall yield of 19\% from 182.

\section{Protectins from DHA}

DHA is also the precursor for the biosynthesis of protectins, also called neuroprotectins when they are produced in neural systems [98]. The "neuro" prefix before protectin D1 (NPD1) results from the biosynthesis location and the potent neuroprotective effects identified [98] - namely, protective actions in the retina and brain and in the induction of pain [99-101]. The anti-inflammatory and pro-resolving protectins have $\mathrm{EC}_{50}$ values in the low nanomolar to picomolar range [77], also exerting anti-apoptotic activity [102]. Protectins beneficial effects against obesity and diabetes have been investigated. GonzalesPeriz et al. [103] reported that biosynthetic formation of SPMs was deregulated in obese mice and in inflamed white adipose tissues, and reduced insulin resistance was observed in white adipose tissues, with DP1 and RvD1 being the dominant DHA-derived SPMs, based on LC/MS-MS. Additionally, Clària et al. [104] showed that an unbalanced level of SPMs are directly connected to insufficient tissue resolution in both in vitro and in vivo models of diabetes and obesity. As the chronic unresolved inflammation in adipose tissues may result in insulin resistance, diabetes, and fatty liver disease, endogenous SPMs such as the PDs, displaying potent pro-resolving and anti-inflammatory bioactions in vivo, become important biotemplates towards drug development targeting obesity and diabetes [77].

\subsection{Biosynthesis of Protectin D1}

The biosynthesis of NPD1/PD1 is initiated with the formation of 17S-HpDHA by 15-LO, leading to the 16(17)-epoxydocosatriene intermediate, which is converted by a hydrolase to the final product PD1/NPD1 with the correct double bond geometry [26] (Scheme 25).

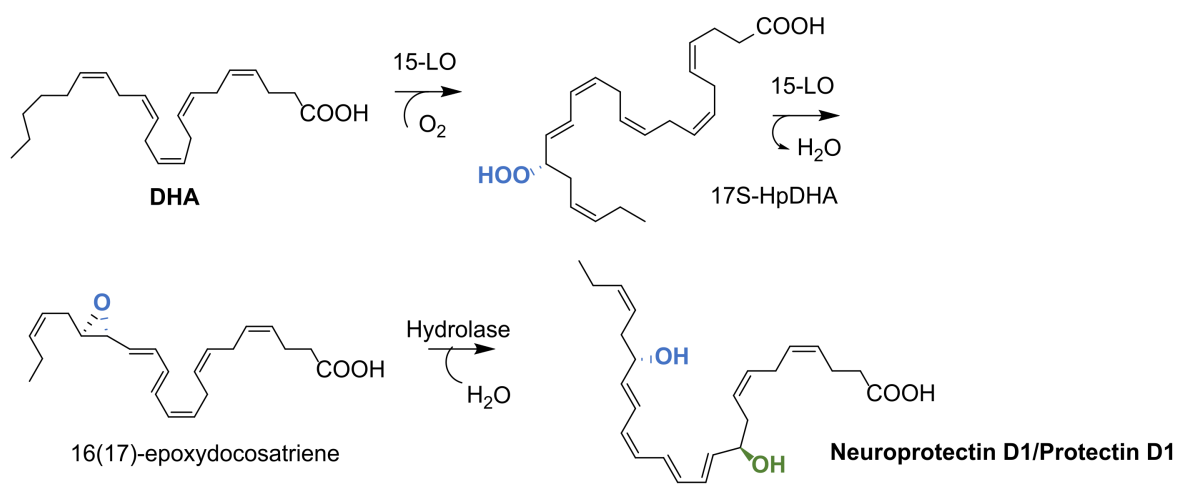

Scheme 25. NPD1/PD1 biosynthesis.

\subsection{Total Synthesis of Protectin D1}

The total synthesis of stereochemically pure NPD1/PD1 has been accomplished by several approaches, as disclosed by Ogawa and Kobayashi in 2011 [105], by Serhan and co-workers in 2012 [106], by Rodríguez and Spur in 2014 [107], and more recently by Sala and co-workers in 2019 [105].

\subsubsection{Ogawa and Kobayashi Approach}

In 2011, a stereoselective total synthesis was reported by Ogawa and Kobayashi [105], the strategy of which was based on the Suzuki coupling to construct PD1 core structure, by 
reacting C22-C13 vinylborane 202 with the vinyl iodide 203 (Scheme 26). The preparation of 202 started by alkylation of 204 with ethyl bromide to give racemic 205, further subjected to the asymmetric Sharpless epoxidation, which gave enantiomerically pure alcohol 206 with the required $(S)$-configuration and the epoxide 207 in $48 \%$ and $46 \%$ yield, respectively. Reaction of 206 with bromine and tetrabutylammonium fluoride gave the bromoalcohol 208, which was protected with TBS to afford 209 in good yield (Scheme 26). Sonogashira coupling with trimethylsilyl acetylene proceeded in very high yield, giving 210, the regioand stereoselective hydrogenation of which provided compound 211, which was desilylated with potassium carbonate prior to reaction with bis(siamyl)borane to give 202 .
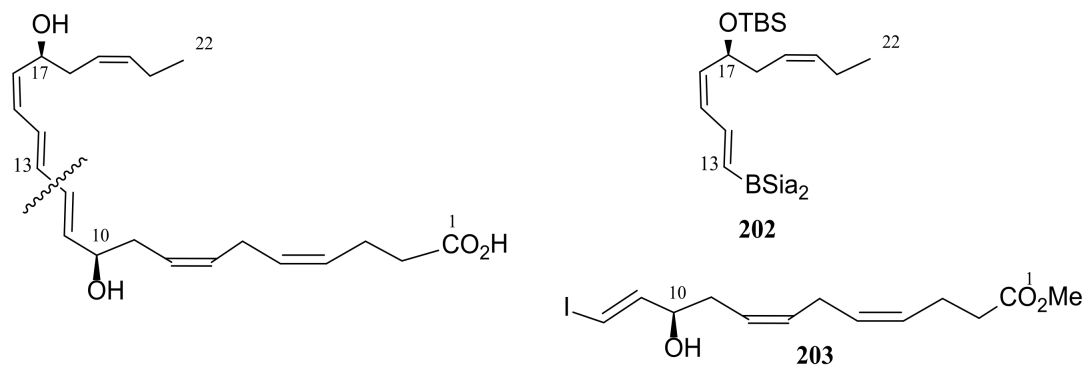

Synthesis of precursor 202<smiles>CCC#CC[C@H](O)/C=C/SC#N</smiles><smiles>CC#CC#CCC(O)C=CS(C)(=O)=O</smiles>

206<smiles>[R20]C(/C=C\Br)CC#CCC</smiles><smiles>C#C[As](C)(C)C</smiles>

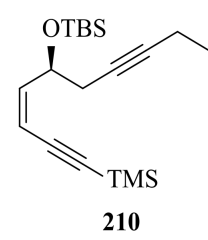

210<smiles>[R]C#C/C=C\C(C/C=C/CC)O[SnH3]</smiles>

Scheme 26. Synthesis of precursor 202, as reported by Ogawa and Kobayashi [105]. Reagents and conditions: i. $\mathrm{CH}_{2}=\mathrm{CHOEt}$ PPTS; ii. BuLi then EtBr, DMPU; iii. $3 \mathrm{~N} \mathrm{HCl}, 71 \%$ over the three steps; iv. $t \mathrm{BuOOH}$ D-DIPT, Ti(OPr $)_{4},-20{ }^{\circ} \mathrm{C}, 12 \mathrm{~h}, 48 \%$ for 206, 99\% ee and $46 \%$ for $207,99 \%$ ee; $\mathrm{v} . \mathrm{Br}_{2}$; vi. TBAF, vii. TBSCl, $65 \%$ over the three steps; viii. $\mathrm{PrNH}_{2}, \mathrm{CuI}, \mathrm{Pd}\left(\mathrm{PPh}_{3}\right)_{4}, 89 \%$; ix. $\mathrm{H}_{2}, \mathrm{Pd} / \mathrm{BaSO}_{4}$, EtOAc, $94 \%$; x. $\mathrm{K}_{2} \mathrm{CO}_{3}, \mathrm{MeOH}, 90 \%$; xi. $\mathrm{Sia}_{2} \mathrm{BH}$ (1.5 equiv.), $0{ }^{\circ} \mathrm{C}, 1 \mathrm{~h}$, THF.

The synthesis of 203 started with the chain elongation of 96, giving 213 in $81 \%$ yield (Scheme 27A). Hydrogenation of the triple bond to the cis double bond succeeded with the Lindlar catalyst in ethyl acetate, in the presence of quinoline to avoid over reduction. Treatment of 213 with iodine and triphenylphosphane generated the iodo derivative 214, which was transformed in the phosphonium salt 215 by further addition of triphenylphosphane. A stereoselective Wittig reaction of the phosphorane, obtained by addition of NaHMDS to the phosphonium salt 215, with the aldehyde afforded the iodotriene 216, partially desilylated at the primary position by the addition of PPTS. Oxidation of the primary alcohol 
to carboxylic acid and esterification with diazomethane gave the ester 218, desilylated to afford 203, synthesized from 96 in 37.8\% overall yield.

A. Synthesis of 203 precursor
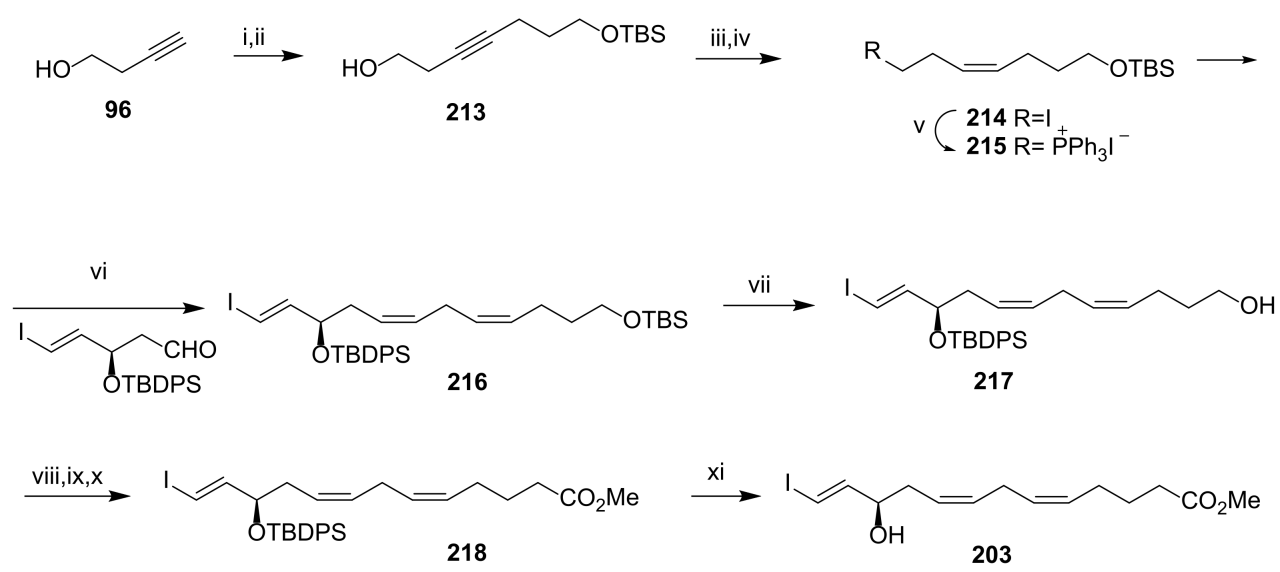

B. Synthesis of Protectin D1

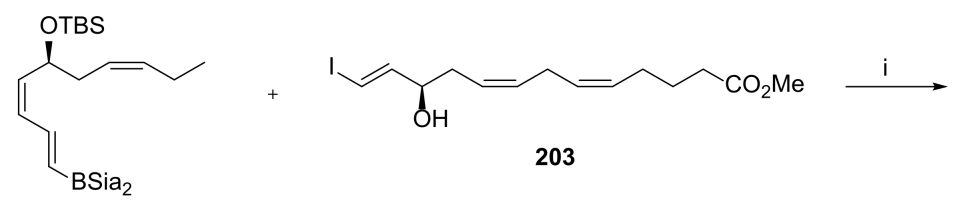

202

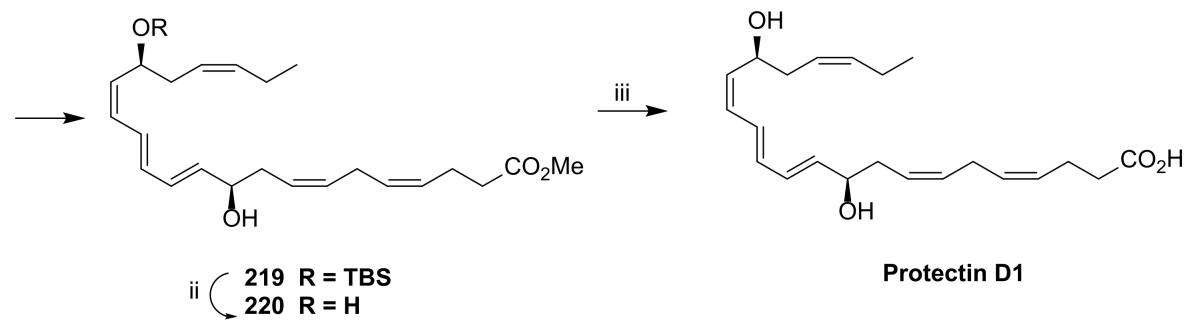

Scheme 27. Synthesis of precursor 203 (A) and of PD1 (B), as reported by Ogawa and Kobayashi [105]. Reagents and conditions: (A). i. $\mathrm{LiNH}_{2}, \mathrm{NH}_{3} / \mathrm{THF}$; ii. $\mathrm{Br}\left(\mathrm{CH}_{2}\right)_{3} \mathrm{OTBS}, 81 \%$; iii. $\mathrm{H}_{2}$, Lindlar cat., quinoline; iv. $\mathrm{I}_{2}, \mathrm{PPh}_{3}$, imidazole; v. $\mathrm{PPh}_{3}, \mathrm{MeCN}, 71 \%$ over the last three steps; vi. NaHMDS, $94 \%$; vii. PPTS, $\mathrm{CH}_{2} \mathrm{Cl}_{2} / \mathrm{EtOH}$ (1:1), quant.; viii. $\mathrm{SO}_{3} \bullet P y$; ix. $\mathrm{NaClO}_{2} ; \mathrm{x} . \mathrm{CH}_{2} \mathrm{~N}_{2}, 73 \%$; xi. TBAF, $90 \%$. (B). i. $\mathrm{Pd}\left(\mathrm{PPh}_{3}\right)_{4}(20 \mathrm{~mol} \%) 2 \mathrm{~N} \mathrm{NaOH}$ (10 equiv.) THF, rt, $1 \mathrm{~h}$; ii. TBAF; iii. $2 \mathrm{~N} \mathrm{~L} \mathrm{iOH} \mathrm{THF,} \mathrm{H}_{2} \mathrm{O}, 42 \%$.

PD1 synthesis was then achieved by Suzuki coupling of 202 and 203 (Scheme 27B), followed by desilylation with TBAF and ester hydrolysis with aq. lithium hydroxide in $42 \%$ yield.

\subsubsection{Serhan Approach}

Serhan and co-workers [106] reported, in 2012, a highly stereocontrolled synthesis of NPD1/PD1 based on a Sonogashira coupling of reaction partners 221 (Scheme 28) and 222 (Scheme 29). The 10(R) and 17(S) configurations were established through ring opening of enantiomerically pure epoxides 224 for the configuration 17(S) (Scheme 29) and 230 for the configuration 10(R) (Scheme 30). (Z)-alkenes were obtained by hydrogenation of the alkynes with the Lindlar catalyst in ethyl acetate at room temperature, in the presence of quinoline, obtaining 227 in very high yield (95\%) (Scheme 29) and 235 in 68\% yield (Scheme 30). In addition, the triene $(11 E, 13 E, 15 Z)$ was introduced at the very end of the synthetic pathway, by triple bond reduction after the Sonogashira reaction of 221 with 222 to avoid $Z / E$ isomerization. The synthesis of 221 was accomplished by Swern oxidation 
of the primary alcohol of $\mathbf{2 2 7}$ to afford aldehyde $\mathbf{2 2 8}$, submitted then to the Corey-Fuchs reaction [105] (Scheme 29), giving 221 obtained in 32.4\% overall yield, covering the required protection and deprotection steps involved in this synthetic route.
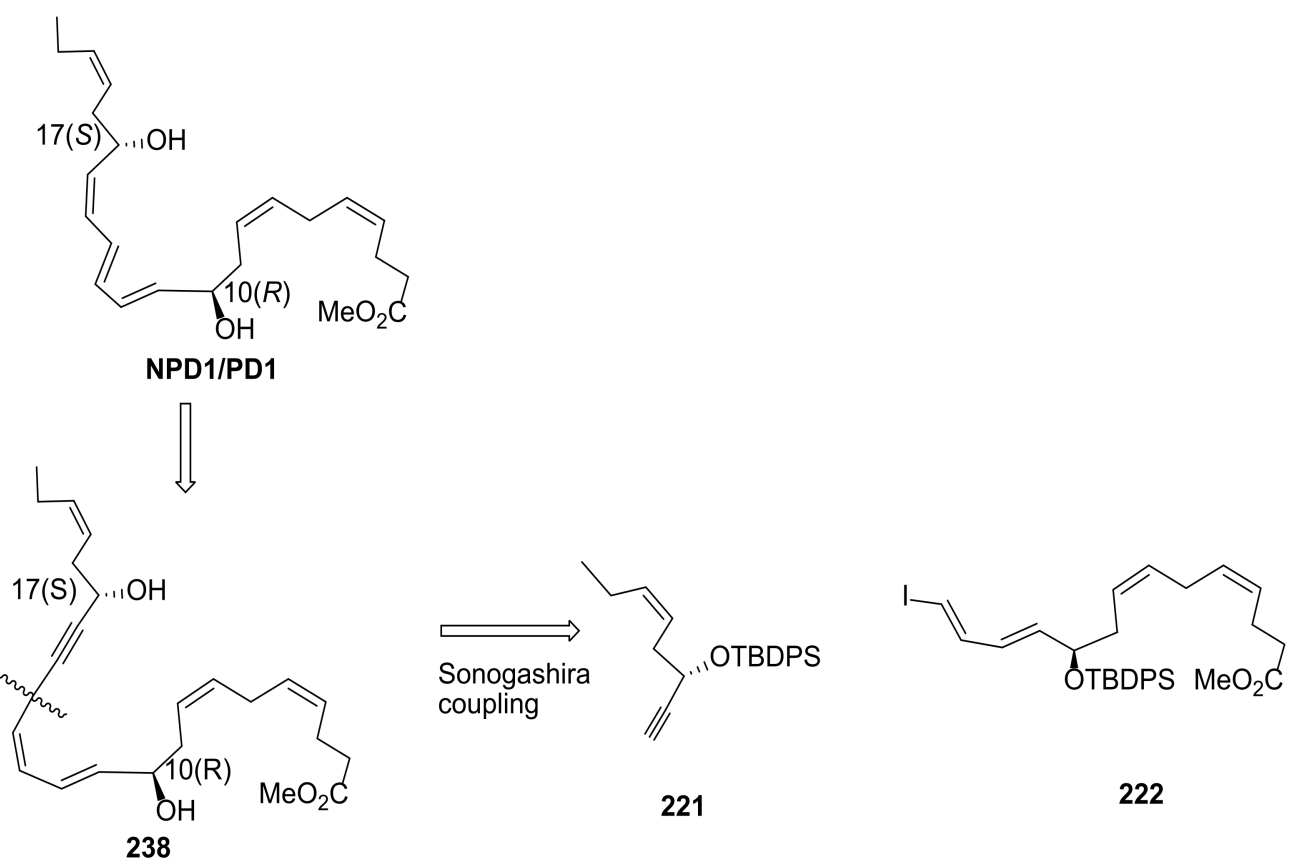

Synthesis of 221

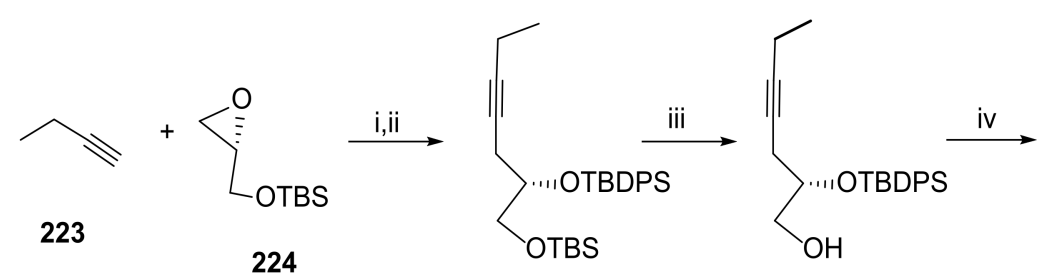

225

226

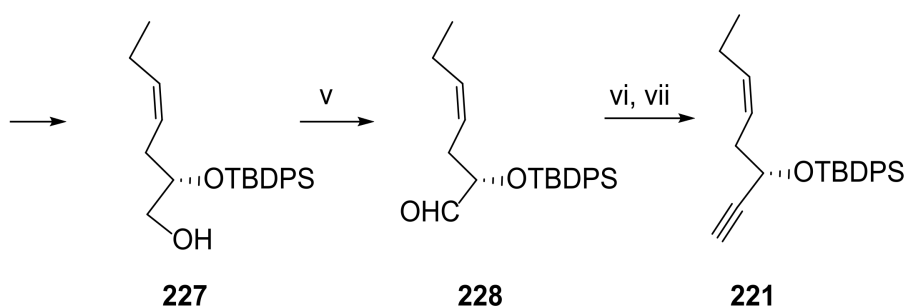

Scheme 28. Sonogashira reaction partners for the total synthesis of PD1 and preparation of 221, as reported by Serhan and co-workers [106]. Reagents and conditions: i. $n \mathrm{BuLi}, \mathrm{BF} . \mathrm{OEt}_{2},-78{ }^{\circ} \mathrm{C}$, THF, 84\%; ii. TBDPS-Cl, imidazole, DMAP, rt, $\mathrm{CH}_{2} \mathrm{Cl}_{2}, 89 \%$; iii. CSA, rt, $\mathrm{CH}_{2} \mathrm{Cl}_{2} / \mathrm{MeOH}, 78 \%$; iv. $\mathrm{H}_{2}$ /Lindlar cat., quinoline, rt, EtOAc, 95\%; v. DMSO, $(\mathrm{COCl})_{2} \mathrm{Et}_{3} \mathrm{~N},-78{ }^{\circ} \mathrm{C}_{,} \mathrm{CH}_{2} \mathrm{Cl}_{2}, 98 \%$; vi. $\mathrm{PPh}_{3}, \mathrm{CBr}_{4}, 0^{\circ} \mathrm{C}, \mathrm{CH}_{2} \mathrm{Cl}_{2}, 72 \%$; vii. $n \mathrm{BuLi}, \mathrm{Et}_{2} \mathrm{O}, 83 \%$. 


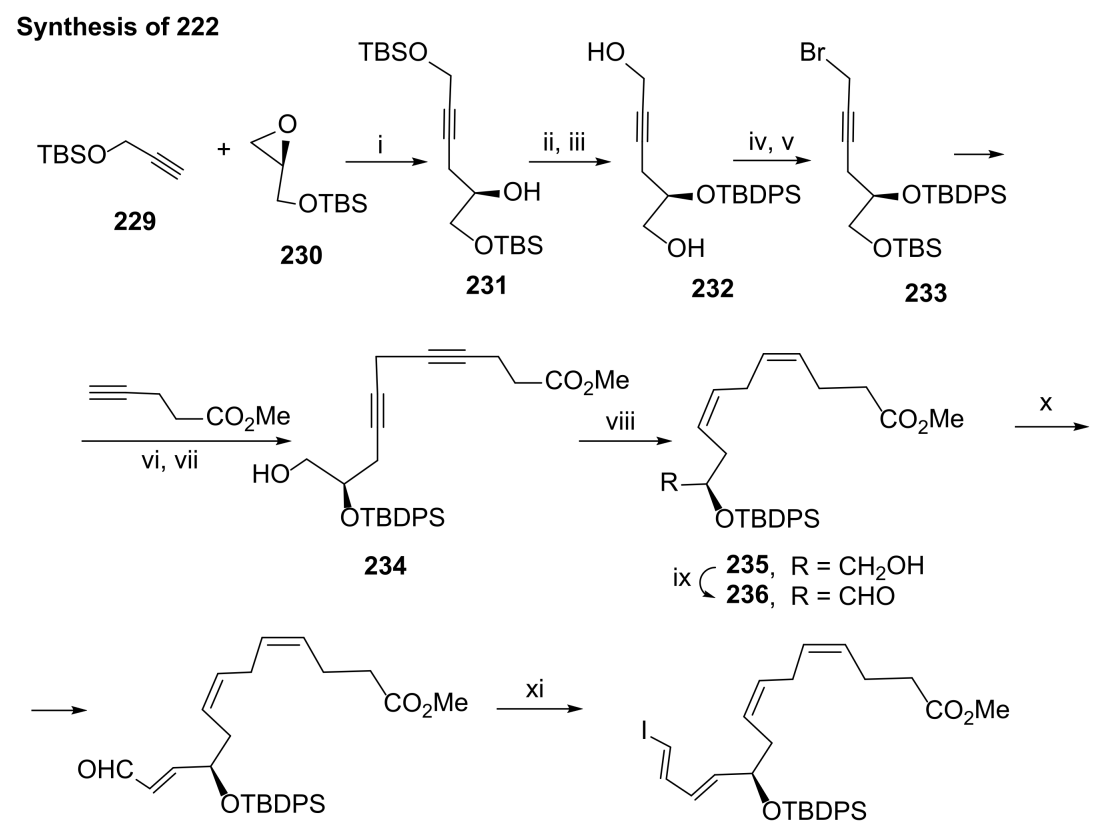

237

222

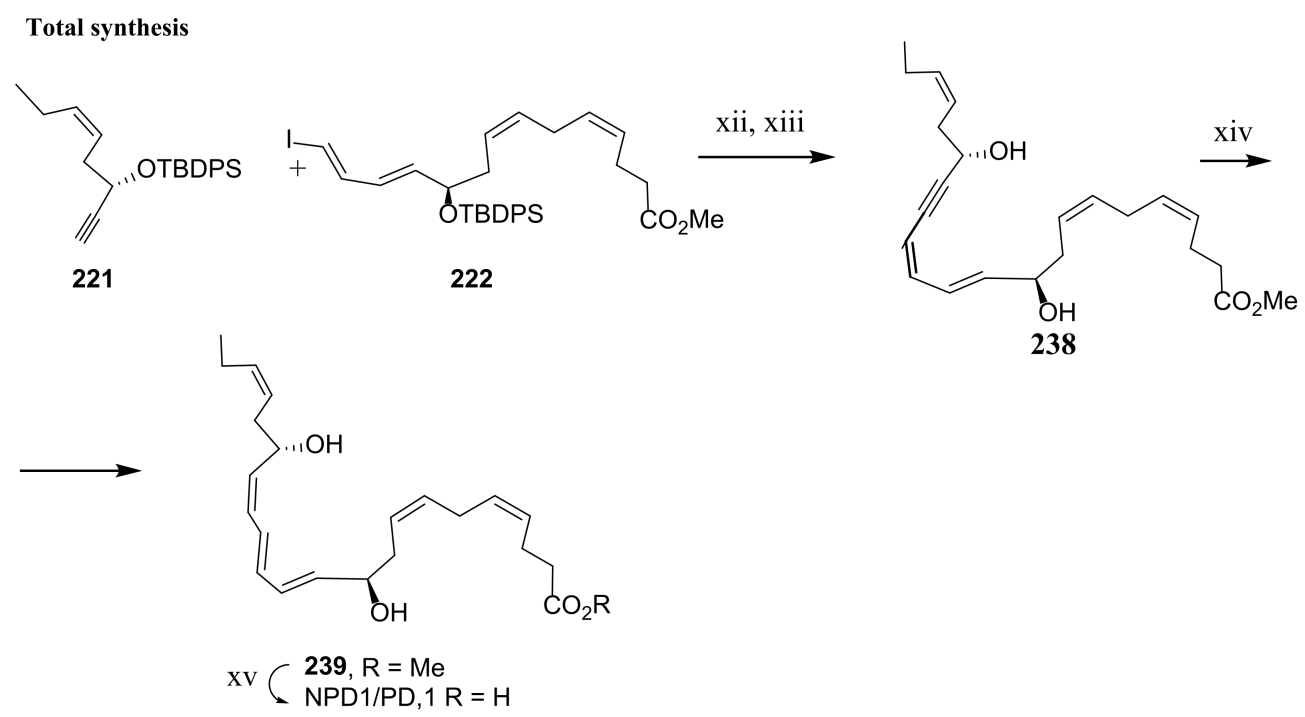

Scheme 29. Preparation of 222 and total synthesis of NPD1/PD1, as reported by Serhan and coworkers [106]. Reagents and conditions: i. $n \mathrm{BuLi}, \mathrm{BF}_{3} \cdot \mathrm{Et}_{2} \mathrm{O},-78{ }^{\circ} \mathrm{C}, \mathrm{THF}, 77 \%$; ii. TBDPS-Cl, imid., DMAP, rt, $\mathrm{CH}_{2} \mathrm{Cl}_{2}, 97 \%$; iii. CSA, rt, $\mathrm{CH}_{2} \mathrm{Cl}_{2} / \mathrm{MeOH}, 81 \%$; iv.NBS, $\mathrm{PPh}_{3}, 0{ }^{\circ} \mathrm{C}_{,} \mathrm{CH}_{2} \mathrm{Cl}_{2}$, $80 \%$; v. TBSOTf, lutidine, $0{ }^{\circ} \mathrm{C}, \mathrm{CH}_{2} \mathrm{Cl}_{2}, 89 \%$; vi. CuI, NaI, $\mathrm{K}_{2} \mathrm{CO}_{3}, \mathrm{rt}, \mathrm{DMF}, 75 \%$; vii. CSA, rt, $\mathrm{CH}_{2} \mathrm{Cl}_{2} / \mathrm{MeOH}, 88 \%$; viii. $\mathrm{H}_{2} /$ Lindlar cat., quinoline, rt, EtOAc, $68 \%$; ix. DMSO, $(\mathrm{COCl})_{2}, \mathrm{Et}_{3} \mathrm{~N}$, $-78{ }^{\circ} \mathrm{C}, \mathrm{CH}_{2} \mathrm{Cl}_{2}, 98 \%$; x. $\mathrm{Ph}_{3} \mathrm{P}=\mathrm{CHCHO}, \mathrm{PhMe}$, reflux, $2 \mathrm{~h}, 90 \%$; xi. $\mathrm{CHI}_{3}, \mathrm{CrCl}_{2}, 0{ }^{\circ} \mathrm{C}, \mathrm{THF}, 67 \%$; xii. $\mathrm{Pd}\left(\mathrm{PPh}_{3}\right)_{4}$ (cat.), $\mathrm{CuI}, \mathrm{rt}, \mathrm{PhH}, 96 \%$; xiii. TBAF, THF, rt, 2 h, 65\%; xiv. $\mathrm{Zn}(\mathrm{Cu} / \mathrm{Ag}), \mathrm{MeOH} / \mathrm{H}_{2} \mathrm{O}$, $40{ }^{\circ} \mathrm{C}, 60 \%$; xv. $\mathrm{NaOH}, \mathrm{MeOH} / \mathrm{H}_{2} \mathrm{O}, \mathrm{rt}, 95 \%$. 


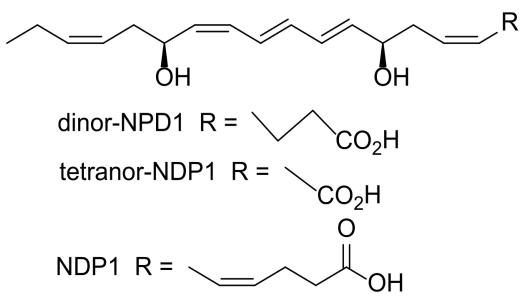

Synthesis of NDP1
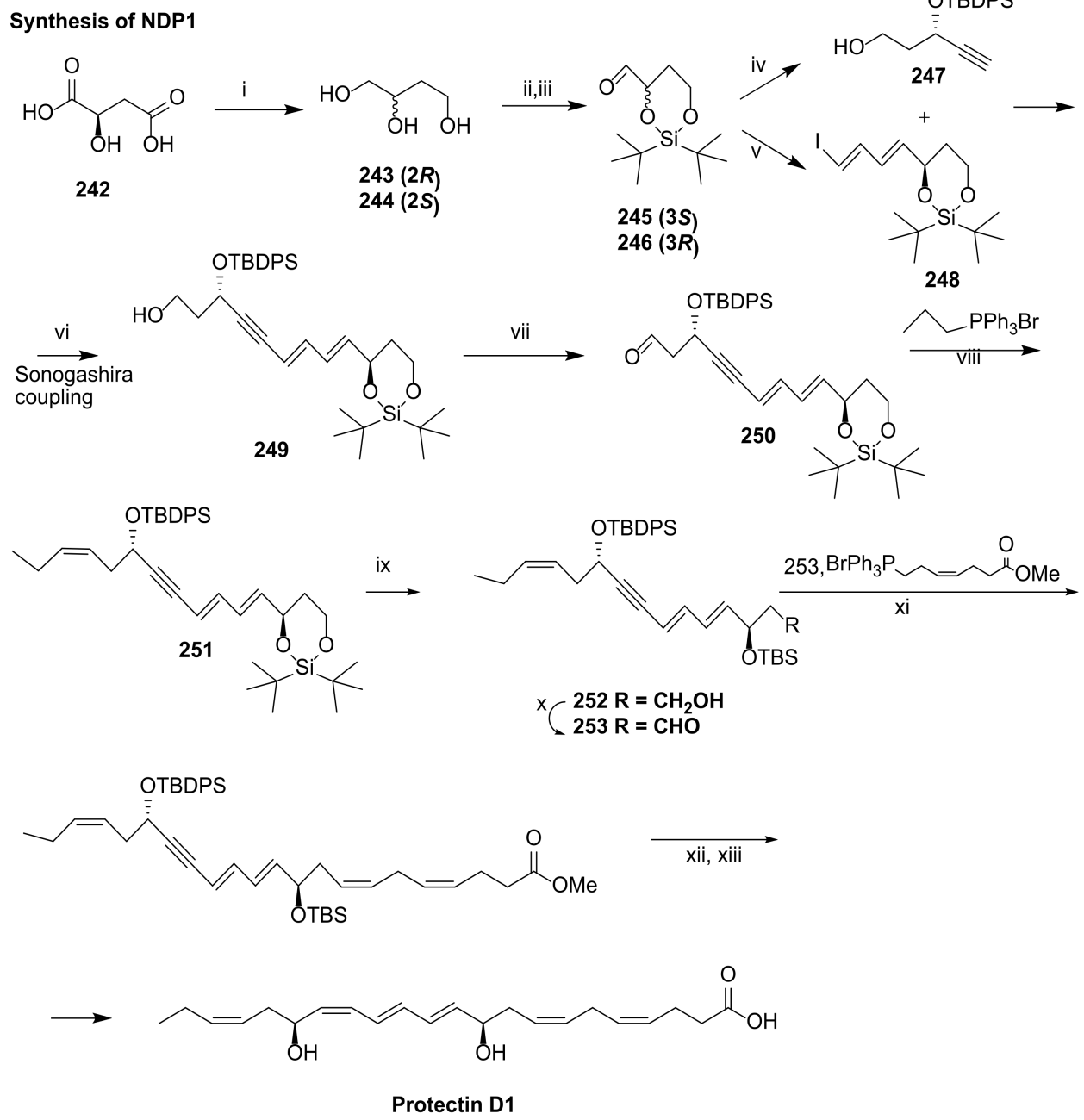

Scheme 30. Synthesis of protectin D1/NPD1, as reported by Balas and co-workers [108]. Reagents and conditions: i. $\mathrm{BH}_{3} . \mathrm{SMe}_{2}, \mathrm{~B}(\mathrm{OMe})_{3}, 98 \%$; ii. $t \mathrm{Bu}_{2} \mathrm{Si}(\mathrm{OTf})_{2}, \mathrm{py}, \mathrm{CH}_{2} \mathrm{Cl}_{2} / \mathrm{DMF}(6: 4),-30{ }^{\circ} \mathrm{C}, 2 \mathrm{~h}$; iii. 1. $(\mathrm{COCl})_{2}$, DMSO; 2 . $\mathrm{Et}_{3} \mathrm{~N}, \mathrm{CH}_{2} \mathrm{Cl}_{2},-78^{\circ} \mathrm{C}$ to rt, $1 \mathrm{~h}, 90 \%$ over the two steps; iv. 1 . $(\mathrm{MeO})_{2} \mathrm{P}(=\mathrm{O})$ $\mathrm{C}\left(=\mathrm{N}_{2}\right)-\mathrm{P}(=\mathrm{O})-\mathrm{CH}_{3}, \mathrm{~K}_{2} \mathrm{CO}_{3}, \mathrm{MeOH}, 0^{\circ} \mathrm{C}$ to $\mathrm{rt}, 3 \mathrm{~h} ; 2$. TBAF, THF, $0^{\circ} \mathrm{C}$ to rt, $2 \mathrm{~h} ; 4.1$. TESCl, $\mathrm{Et}_{3} \mathrm{~N}$, $\mathrm{CH}_{2} \mathrm{Cl}_{2},-25^{\circ} \mathrm{C}, 15 \mathrm{~h} ; 5$. TBDPSCl, TES deprotection, $44 \%$ over the 5 steps; v. $1 . \mathrm{Ph}_{3} \mathrm{P}=\mathrm{CHCHO}$, $\mathrm{CH}_{3} \mathrm{CN}, 30{ }^{\circ} \mathrm{C} ; \mathrm{Me}_{3} \mathrm{SiCHN}_{2}, \mathrm{LDA},-78{ }^{\circ} \mathrm{C}$ to $0{ }^{\circ} \mathrm{C}, \mathrm{THF}, 2.5 \mathrm{~h} ; 3$. a. $\mathrm{ZrCl}_{2}(\mathrm{Cp})_{2}, \mathrm{DIBAL}, \mathrm{b}$. THF, $\mathrm{I}_{2}$; $52 \%$ over the three steps; vi. $\mathrm{Pd}\left(\mathrm{PPh}_{3}\right)_{4}, \mathrm{CuI}, \mathrm{THF}, 91 \%$; vii. 1. $(\mathrm{COCl})_{2}, \mathrm{DMSO} ; 2 . \mathrm{Et}_{3} \mathrm{~N}, \mathrm{CH}_{2} \mathrm{Cl}_{2}$, $-78{ }^{\circ} \mathrm{C}$ to rt, $1 \mathrm{~h}, 95 \%$; viii. NaHMDS, THF, $-78{ }^{\circ} \mathrm{C}, 3 \mathrm{~h}$; ix. 1 . TBAF, $0{ }^{\circ} \mathrm{C}$ to rt, $1 \mathrm{~h} ; 2$. TBSCl, imidazole, $\mathrm{CH}_{2} \mathrm{Cl}_{2}, 0^{\circ} \mathrm{C}$ to rt, $1 \mathrm{~h} ; 3$. PPTS, $\mathrm{EtOH}, 0^{\circ} \mathrm{C}$ to rt, $5.5 \mathrm{~h} ; \mathrm{x}$. 1. $(\mathrm{COCl})_{2}, \mathrm{DMSO} 2 . \mathrm{Et}_{3} \mathrm{~N}$, $\mathrm{CH}_{2} \mathrm{Cl}_{2},-78{ }^{\circ} \mathrm{C}$ to $\mathrm{rt}, 1 \mathrm{~h}, 33 \%$ over the last five steps; xi Base, THF; xii. $\mathrm{Zn}(\mathrm{Cu}-\mathrm{Ag}), 26 \%$; $x$ iii. $\mathrm{LiOH}$ (1M), $\mathrm{MeOH}, 97 \%$.

The synthesis of $\mathbf{2 2 2}$ (Scheme 30) succeeded by Swern oxidation of $\mathbf{2 3 5}$ to aldehyde 236, followed by Wittig reaction to install the $\alpha, \beta$-unsaturated aldehyde, which was subjected to Takai olefination to afford 222, synthesized in $11.4 \%$ overall yield. The total synthesis ended with the Sonogashira reaction coupling 221 and 222 in $96 \%$ yield, desilylation, $\mathrm{Zn}(\mathrm{Ag} / \mathrm{Cu})$ reduction of the triple bond, and ester hydrolysis (Scheme 30). 


\subsubsection{Approach by Balas and Sala}

In 2019, Balas and Sala groups [108] investigated the metabolic process of NPD1 and reported a new total synthesis of NPD1 and that of its two major metabolites, tetranorNDP1 and dinor-NDP1 (Scheme 30), giving the first evidence of $\beta$-oxidation in SPMs. Noteworthily, tetranor-NDP1 kept the bioactivity of NPD1 by inhibiting neutrophil chemotaxis in vitro and neutrophil tissue infiltration in vivo, while dinor-NDP1 was not active. The key reaction for building the NDP1 structure core is the Sonogashira coupling of 245 and 246 for the preparation of the key intermediate 247 (Scheme 30). The installation of the two chirality centres with the required configuration was achieved by using (2S)-butane1,2,4-triol (241) as starting material for the preparation of (245) and its enantiomer 242 for the synthesis of $\mathbf{2 4 6}$, both accessed in five reaction steps. Although the $(R)$-triol enantiomer is commercially available, the synthetic route became cheaper when it was prepared starting from malic acid with the $(R)$ configuration. Silyl protection of the 2,4-diol and Swern oxidation of the remaining primary alcohol gave compounds 243 and 244 in high yield. The synthesis of pent-4-yn-ol 245 was achieved with by reaction of the aldehyde 243 with dimethyl(1-diazo-2-oxopropyl)phosphonate, the Bestmann-Ohira reagent to prepare alkynes from aldehydes [109], followed by a sequence of protection and deprotection steps which furnished $\mathbf{2 4 5}$ in $44 \%$ yield from 243. The iododiene 246 was achieved by a three reaction pathway starting with a Wittig reaction to furnish an $\alpha, \beta$-unsaturated aldehyde which underwent a Colvin rearrangement with trimethylsilyldiazomethane and lithium diisopropylamide, affording a terminal alkyne, the quantitative hydrozirconation of which, followed by iodination [108,110], furnished 246 in 52\% yield from 244 . Swern oxidation of Sonogashira reaction product 247 furnished aldehyde 248, the Wittig reaction of which with the phosphorane generated by triphenyl(propyl)phosphonium bromide and sodium hexamethyldisilazane (NaHDMS) afforded 249, embodying the terminal (Z)-alkene as required. Desilylation with TBAF, protection with $\mathrm{TBSCl}$, and deprotection of the primary alcohol with PPTS gave 250, which underwent Swern oxidation to aldehyde 251. A Wittig reaction was used to introduce Protectin D1 fragment C1-C8, followed by TBDPS deprotection with TBAF, triple bond reduction with $\mathrm{Zn}(\mathrm{Ag}-\mathrm{Cu})$ in $26 \%$ yield over the three steps. Ester hydrolysis succeeded with aqueous LiOH to give NDP1 in 97\% yield. This synthetic pathway covered 27 steps, furnishing NPD1 in 2.84\% yield.

\section{Maresins from DHA}

Maresins have been discovered more recently, being the third-largest family of SPMs which are biosynthesized from DHA. Biosynthesis of maresins starts in M2 macrophages and is initiated by an epoxygenation reaction (see Section 5.1). Maresin 1 (MaR1) and maresin 2 (MaR2) are active anti-inflammatory mediators with a powerful protective effect in inflammation, oxidative stress, and immune diseases as protective mediators of macrophage function [85]. Maresins protect the human body, limiting neutrophil infiltration, enhancing macrophage phagocytosis, reducing the production of pro-inflammatory factors, stimulating tissue regeneration, and controlling pain. MaRs derived from DHA show action in metabolic diseases, nervous system diseases, and kidney and inflammatory bowel diseases, as well as in tissue regeneration and pain control [77,86]. MaR-1 appears to be a molecule with potential for the treatment of motor neuron diseases such as amyotrophic lateral sclerosis (ALS) or spinal muscular atrophy (SMA), which are fatal neurodegenerative diseases that cause loss of motor function and progressive degeneration [55]. In addition, MaR1 attenuates the generation of reactive oxygen species in response to high glucose levels [87], reduces kidney injury and serum creatinine levels in a sepsis-associated kidney injury model [81], and preserves kidney function and inhibits NF-kB activity in a renal ischaemia-reperfusion injury model [88].

\subsection{Biosynthesis of Maresin 1 and Maresin 2}

The biosynthesis of maresins occurs primarily in M2 macrophages. The first reaction involves the formation of a hydroperoxyDHA on the fourteenth carbon atom by 
12-lipoxygenase, a key enzyme in the synthesis of maresins, generating $14 S-\mathrm{HpDHA}$. This molecule suffers epoxidation through 12-LOX being converted to 13S,14S-epoxy-maresin. MaR-1 and Mar-2 are produced by enzymatic hydrolysis with epoxide hydrolase and with soluble epoxide hydrolase (sHE), respectively, as depicted in Scheme 31. [25,40,77,85,86,89,90].

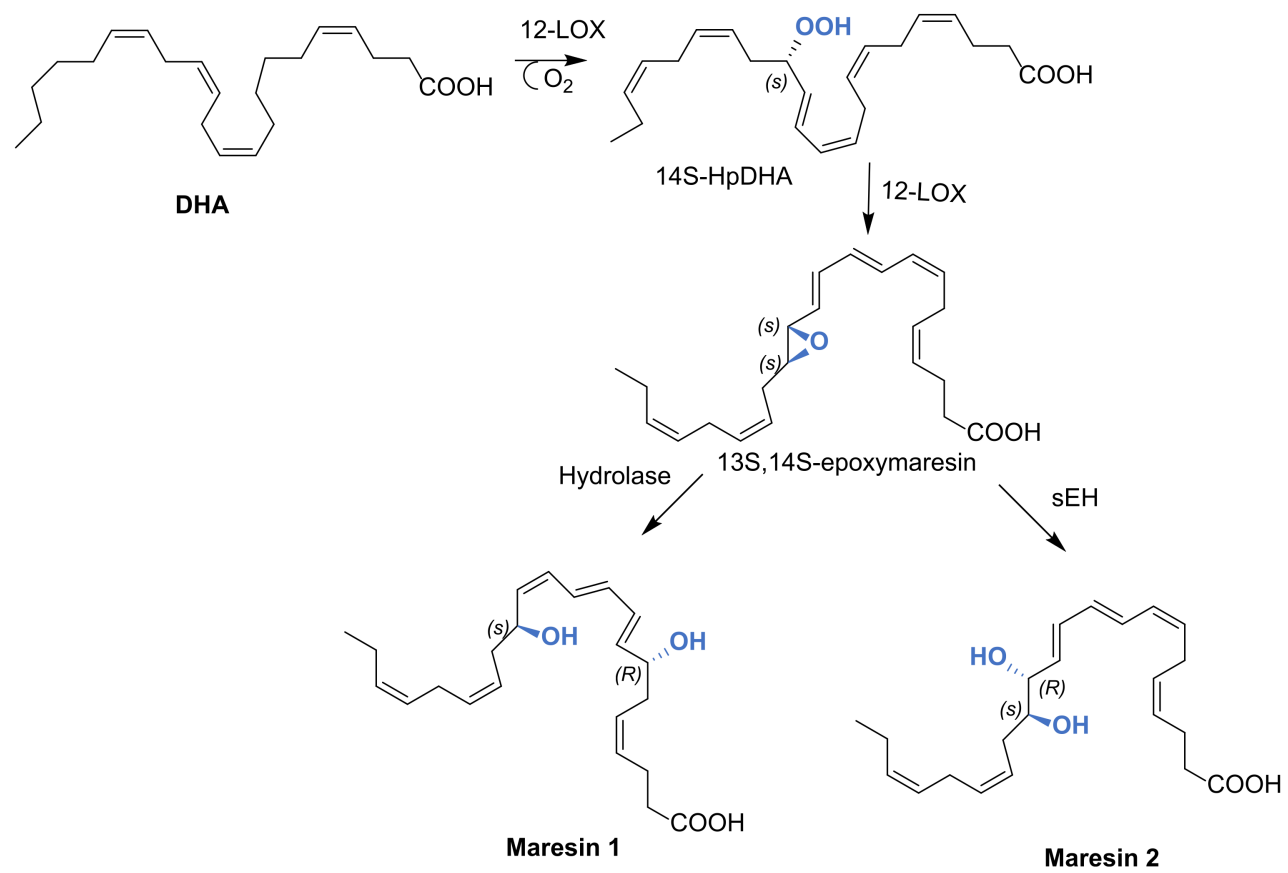

Scheme 31. Maresin 1 and maresin 2 biosynthesis [104,111].

\subsection{Total Synthesis of Maresin 1 and Maresin 2}

The first total synthesis of maresin 1 was presented in 2011 by Inoue et al. [112], although it was not assigned to maresin 1 because the stereochemistry of the C7 chirality centre was unknown, and the total synthesis of maresin 1 with the established structure given in Scheme 32 was reported in 2012 by Rodríguez and Spur [113]. Their synthetic strategy was based on a Sonogashira reaction coupling compounds 253 and $\mathbf{2 5 4}$. Scheme 32 illustrates the retrosynthesis of Mar1, showing that the triple bond resulting from Sonogashira coupling is reduced to a cis double bond with $\mathrm{Zn}(\mathrm{Ag} / \mathrm{Cu})$, while the configuration of the C14 chirality centre is introduced by Jacobsen kinetic resolution of epoxide racemic mixture 255. The C12-C22 fragment was prepared from 2-deoxy-D-erythro-pentopyranose 256, used as the source of chirality for C17.

The preparation of the C1-C11 fragment 253 was achieved in 10 steps in $4.5 \%$ overall yield, starting with the coupling of allyl bromide 257 with pent-4-yn-1-ol 258 catalysed by CuI, followed by Jones oxidation and esterification (Scheme 33). The epoxidation of the terminal double bond with $m$-chloroperoxybenzoic acid gave racemic epoxy ester 261. Jacobsen hydrolytic kinetic resolution of 261 with $\mathrm{H}_{2} \mathrm{O}$ and $5 \%(S, S)$-salen-Co catalyst afforded 262 with more than 95\% ee. Diol protection with triethylsilyl chloride and triple bond reduction with $\mathrm{Zn}(\mathrm{Ag} / \mathrm{Cu})$ furnished 264, which was regioselectively deprotected at the primary position to be subjected to Swern oxidation to aldehyde 265 . Wittig reaction furnished the $\alpha, \beta$-unsaturated aldehyde 266, converted to 253 by Takai olefination [92]. The Sonogashira reaction partner 254 was prepared in only four steps starting from 256, which was protected with isopropylidene and subjected to Wittig reaction, furnishing 268 in good yield (Scheme 34). Iodination and LDA induced deprotonation-elimination gave the target compound 254 in $17.6 \%$ overall yield. The total synthesis of maresin 1 succeeded by Sonogashira coupling of 253 and 254 in good yield (Scheme 35). TES deprotection with PPTS, Lindlar reduction of the triple bond and ester hydrolysis gave maresin 1 in high yield, which co-eluted with a sample of natural maresin 1. 


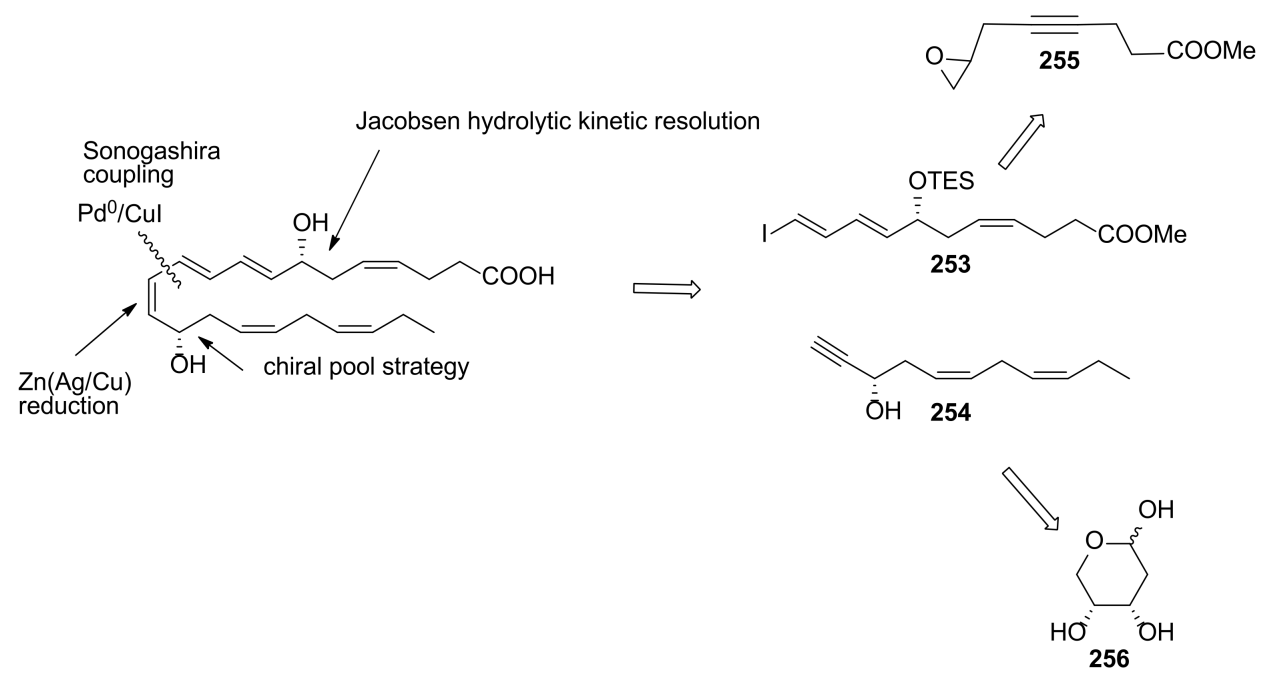

Scheme 32. Retrosynthesis of maresin 1, as reported by Rodríguez and Spur [113].

Synthesis of precursor 253
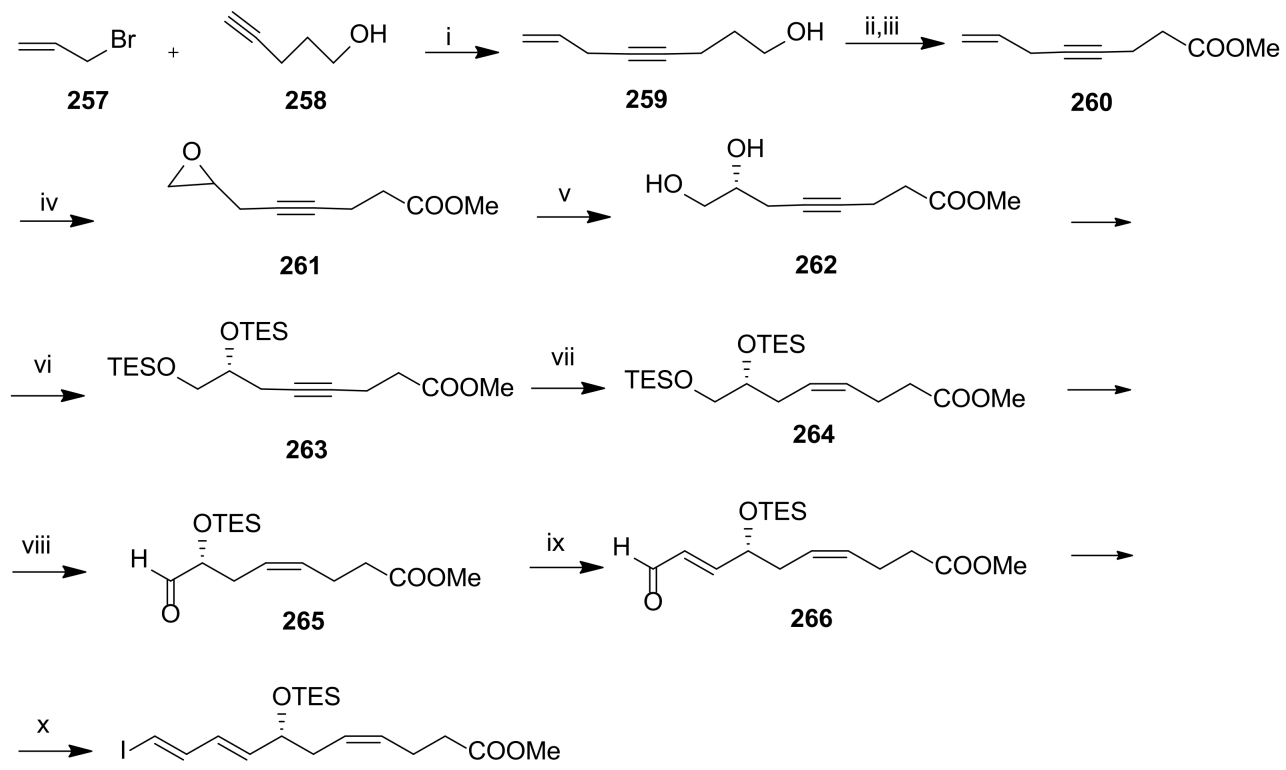

253

Scheme 33. Synthesis of precursor 253, as reported by Rodríguez and Spur [113]. Reagents and conditions: i. $\mathrm{Na}_{2} \mathrm{SO}_{3}$, cat.CuI, $\mathrm{K}_{2} \mathrm{CO}_{3}, \mathrm{H}_{2} \mathrm{O}, 92 \%$; ii. Jones reagent, acetone, $69 \%$; iii. $10 \% \mathrm{Me}_{3} \mathrm{SiCl}$, $\mathrm{CH}_{3} \mathrm{OH}, 2$,2-dimethoxypropane, rt, $90 \%$; iv. $m \mathrm{CPBA}, \mathrm{NaHCO}_{3}, \mathrm{CH}_{2} \mathrm{Cl}_{2}, 0{ }^{\circ} \mathrm{C}, 75 \%$; v. (S,S)-(salen)Co (III)(OAc)catalyst, $\mathrm{H}_{2} \mathrm{O}$, ether, $0{ }^{\circ} \mathrm{C}$ to $\mathrm{rt}, 45 \%$; vi. TESCl, imidazole, $\mathrm{Et}_{3} \mathrm{~N}, \mathrm{DMF}, 0{ }^{\circ} \mathrm{C}$ to $\mathrm{rt}, 95 \%$; vii. $\mathrm{H}_{2}$, Lindlar cat., hexane, $99 \%$; viii. $(\mathrm{COCl})_{2}, \mathrm{DMSO}, \mathrm{CH}_{2} \mathrm{Cl}_{2}$, then $\mathrm{Et}_{3} \mathrm{~N}, 83 \%$; ix. $\mathrm{Ph}_{3} \mathrm{P}=\mathrm{CH}-\mathrm{CHO}$, benzene, $70{ }^{\circ} \mathrm{C}, 43 \%$; $x . \mathrm{CrCl}_{2}, \mathrm{CHI}_{3}, \mathrm{THF}, 0{ }^{\circ} \mathrm{C}, 69 \%$. 


\section{Synthesis of precursor 254}

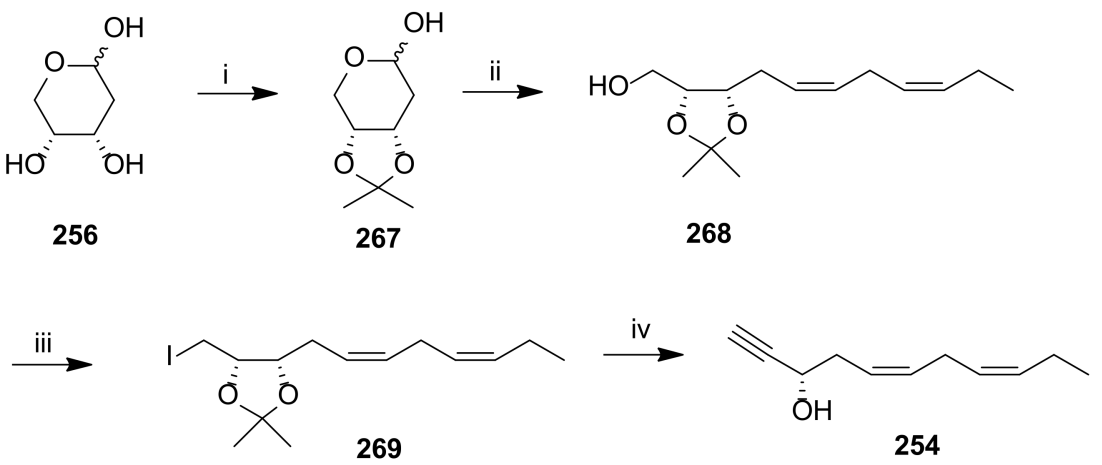

Scheme 34. Synthesis of precursor 254, as reported by Rodríguez and Spur [113]. Reagents and conditions: i.2-methoxypropene, PPTS, EtOAc, $0{ }^{\circ} \mathrm{C}$ to rt, $50 \%$; ii. (Z)- $\mathrm{CH}_{3} \mathrm{CH}_{2} \mathrm{CH}=\mathrm{CH}\left(\mathrm{CH}_{2}\right)_{2} \mathrm{PPh}_{3} \mathrm{I}^{-}$, BuLi, THF, $-78{ }^{\circ} \mathrm{C}$ to $0{ }^{\circ} \mathrm{C}, 81 \%$; iii. $\mathrm{I}_{2}, \mathrm{Ph}_{3} \mathrm{P}$, imidazole, toluene, $60{ }^{\circ} \mathrm{C}, 82 \%$; iv. LDA, THF, $-78{ }^{\circ} \mathrm{C}, 53 \%$.

Maresin 1 - Total Synthesis

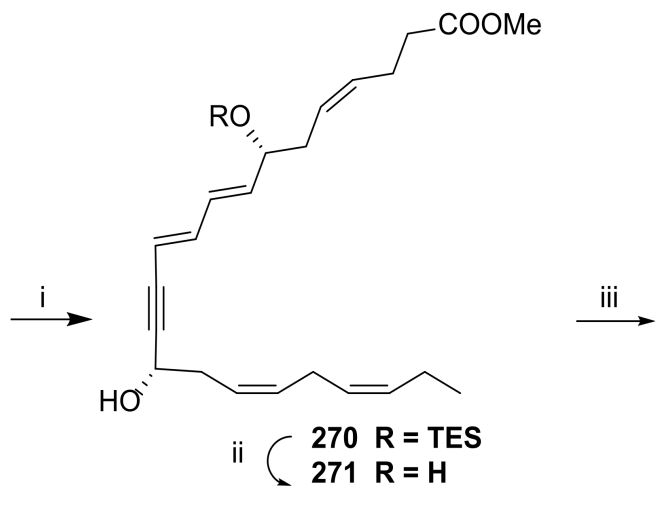

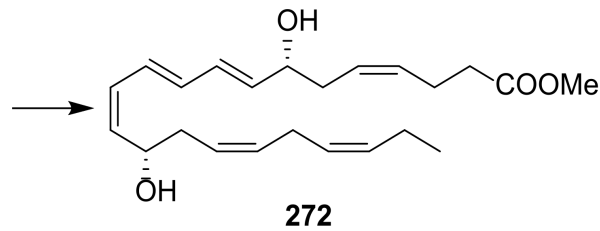

272<smiles>CC/C=C\C/C=C\C[C@@H](O)/C=C/C=C/C[C@H](O)/C=C\C=C/CCC(=O)O</smiles>

Maresin 1

Scheme 35. Synthesis of maresin 1, as reported by Rodríguez and Spur [113]. Reagents and conditions: i. $\mathrm{Pd}\left(\mathrm{PPh}_{3}\right)_{4}, \mathrm{CuI}$, piperidine, benzene, rt, $81 \%$; ii. $\mathrm{PPTS}, \mathrm{CH}_{3} \mathrm{OH}, 0{ }^{\circ} \mathrm{C}, 96 \%$; iii. $\mathrm{Zn}(\mathrm{Cu} / \mathrm{Ag}), \mathrm{CH}_{3} \mathrm{OH}$, $\mathrm{H}_{2} \mathrm{O}, 40-45^{\circ} \mathrm{C}, 66 \%$; iv. $1 \mathrm{~N} \mathrm{LiOH}, \mathrm{CH}_{3} \mathrm{OH}, \mathrm{H}_{2} \mathrm{O}, 0{ }^{\circ} \mathrm{C}$, then satd. $\mathrm{NaH}_{2} \mathrm{PO}_{4}, 77 \%$.

The first total synthesis of maresin 2 was carried out by Rodríguez and Spur in 2015 [64]. As shown in Scheme 36, Wittig olefination is the key reaction, assembling molecule fragments for building its core structure. The chirality centres were introduced using a chiral pool strategy starting from 2-deoxy-D-erythro-pentopyranose (256). The preparation of the key intermediates $\mathbf{2 7 3}, \mathbf{2 7 4}$, and 275 is illustrated in Schemes 37 and 38. 


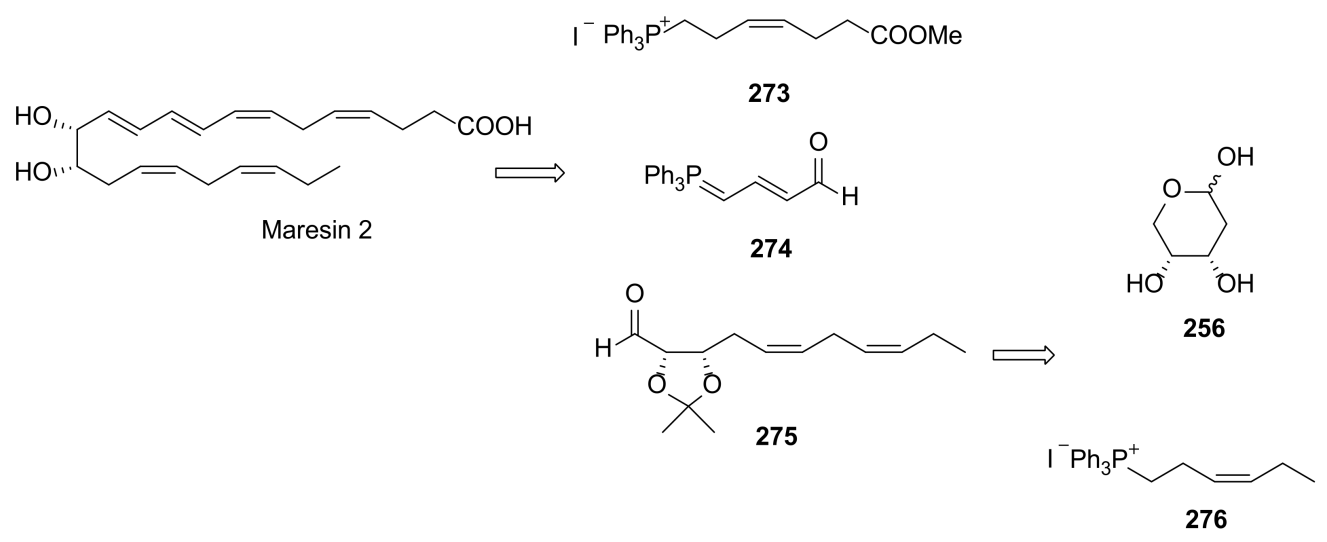

Scheme 36. Retrosynthetic approach of maresin 2, as reported by Rodríguez and Spur [64].

\section{A. Synthesis of precursor 273}

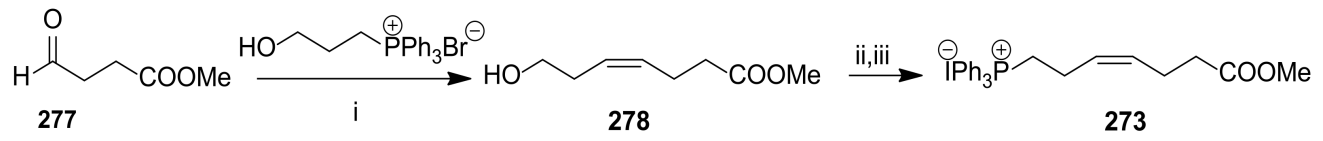

B. Synthesis of precursor 275

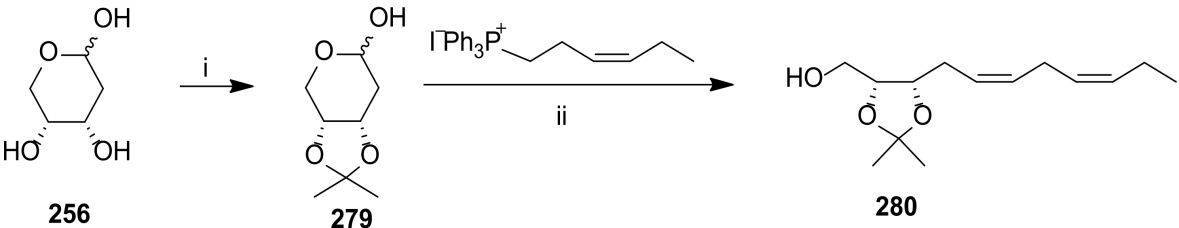

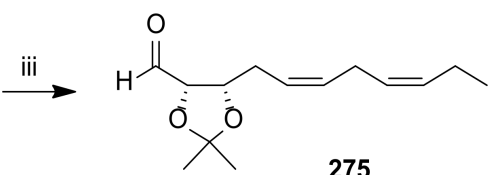

Scheme 37. Synthesis of precursors 273 (A) and 275 (B), as reported by Rodríguez and Spur [64] and by Balas and co-workers [110]. Reagents and conditions: (A). i. KHMDS, THF, $0^{\circ} \mathrm{C}$ to rt, TMSCl, $0{ }^{\circ} \mathrm{C}, 276,-78^{\circ} \mathrm{C}$ to rt, then $1 \mathrm{~N} \mathrm{HCl}, 0{ }^{\circ} \mathrm{C}$ to $\mathrm{rt}, 45 \%$; ii. $\mathrm{Ph}_{3} \mathrm{P}$, imidazole, $\mathrm{I}_{2}, 99 \%$; iii. $\mathrm{Ph}_{3} \mathrm{P} ; \mathrm{MeCN}$; (B). i. 2-methoxypropene, PPTS, EtOAc, $0{ }^{\circ} \mathrm{C}$ to rt, $68 \%$; ii. $n \mathrm{BuLi}, \mathrm{THF},-78{ }^{\circ} \mathrm{C}, 80 \%$; iii. Dess-Martin oxidation, $\mathrm{CH}_{2} \mathrm{Cl}_{2}$, rt.

The phosphonium iodide $\mathbf{2 7 3}$ was prepared from aldehyde $\mathbf{2 7 7}$ via cis-selective Wittig reaction with hydroxypropylphosphonium bromide, furnishing 278, the iodination and treatment of which with triphenylphosphane afforded 273 in very high yield (Scheme 37A). The synthesis of C12-C22 precursor 275 (Scheme 37B) was accomplished from 256 through cis-diol protection with the group isopropylidene, followed by reaction with the (3Z)-3(hexen-1-ylidene)triphenylphosphorane generated in situ by basic treatment of the phosphonium iodide, providing the (Z,Z)-diene $\mathbf{2 8 0}$ in high yield. Dess-Martin oxidation [114] of the primary alcohol afforded the target aldehyde 275 . The Wittig reaction with phosphorane 274 provided aldehyde 281, which by Wittig cis-olefination afforded 282, the precursor transformed in maresin 2 (Scheme 38) by acid hydrolysis of the propylidene group followed by basic ester hydrolysis. 

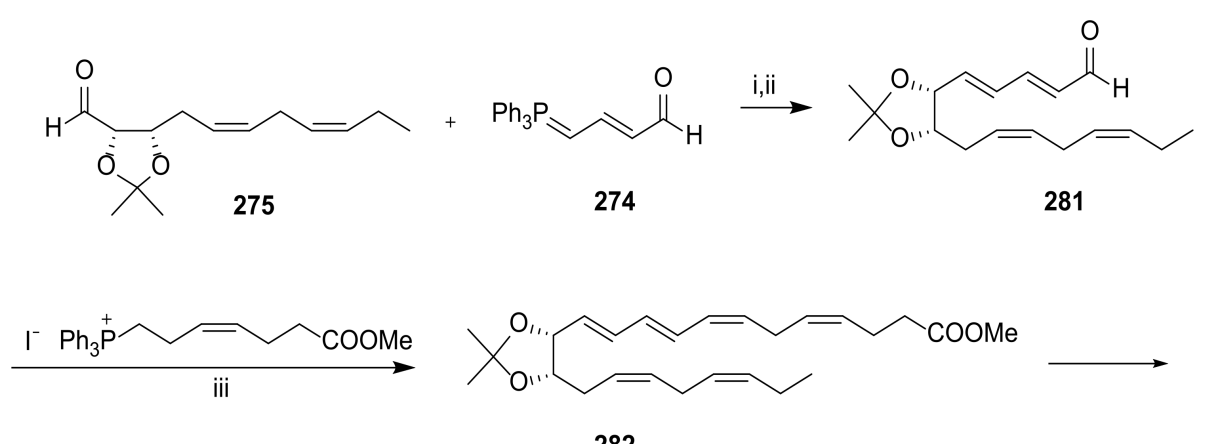

282

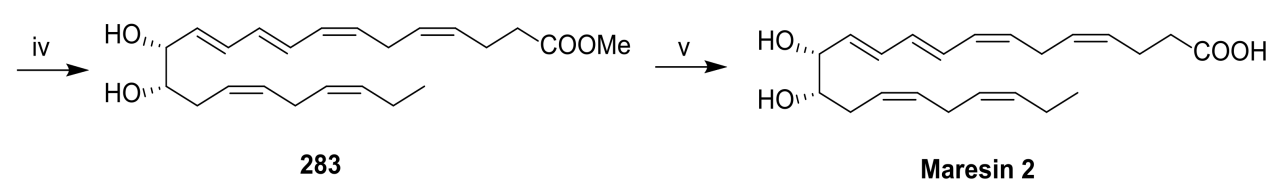

Scheme 38. Synthesis of maresin 2, as reported by Rodríguez and Spur [64]. Reagents and conditions: i. $\mathrm{CH}_{2} \mathrm{Cl}_{2}, \mathrm{rt}, 37 \%$; ii. cat. $\mathrm{I}_{2}$, benzene, rt, $88 \%$; iii. $\mathrm{KHMDS}, \mathrm{THF},-78{ }^{\circ} \mathrm{C}$ to $0{ }^{\circ} \mathrm{C}, 37 \%$; iv. PTSA, $\mathrm{CH}_{3} \mathrm{OH}, 0^{\circ} \mathrm{C}, 72 \%$; v. $1 \mathrm{~N} \mathrm{LiOH}, \mathrm{CH}_{3} \mathrm{OH}, \mathrm{H}_{2} \mathrm{O}, 0{ }^{\circ} \mathrm{C}$, then sat. $\mathrm{NaH}_{2} \mathrm{PO}_{4}, 87 \%$.

\subsection{Maresin-Like Lipid Mediators}

Discovered in 2014, maresin-L1 (14S,22-dihydroxydocosa-4Z,7Z,10Z,12E,16Z,19Zhexaenoic acid (14S,22-diHDHA) and its enantiomer maresin-L2 (14R,22-diHDHA) [115] (Scheme 39) are produced by macrophages from DHA [116]. Similar to maresins, their biosynthesis involves 12- or 15-lipoxygenase-catalyzed (14S)-hydroxylation, while for maresin-L2 the (14R)-hydroxylation is catalysed by cytochrome P450. Maresins-like mediators have a biosynthetic pathway involving a hydroxylation by P450 enzyme(s) at C22 of the polyunsaturated linear chain containing six double bonds and twenty-two carbons. Maresin-Ls act as autocrine/paracrine factors for the reparative functions of leukocytes and PLT in wounds and ameliorate macrophage inflammatory activation, suppressing the chronic inflammation in diabetic wounds caused by activation of macrophages [116]. Thus, these lipid mediators may contribute to the roles of macrophages in wound healing and might be able to be used to restore the impaired reparative function of macrophages for the healing of diabetic wounds [116].

In 2019, the first stereoselective synthesis of maresin-like lipid mediators (MLs) was disclosed [116]. The key steps are the Wittig reaction of aldehyde 285 with the phosphorane derived from 284 and the kinetic resolution of $\mathbf{2 8 6}$ by asymmetric epoxidation, presented in Scheme 39. The preparation of phosphonium salt $\mathbf{2 8 4}$ was achieved by alkylation of tert-butyl acetate to afford 288, which was coupled with vinyl alcohol to give hydroxydiyneester 290 (Scheme 40). Partial hydrogenation of the triple bond with P-2 nickel afforded hydroxy diene ester 291, which was iodinated and treated with triphenylphosphane, furnishing phosphonium iodide 284. The epoxides (3S)-297 and (3R)-297 are the precursors for the synthesis of maresin-L1 and maresin-L2. They were synthesized from racemic aldehyde 291 by a five- and a six-step sequence, respectively (Scheme 41 ). The first step is the stereoselective Wittig reaction with the phosphorane derived from phosphonium salt 292 by treatment with the base $\mathrm{NaN}\left(\mathrm{SiMe}_{3}\right)_{2}$. Desilylation afforded diol 294, which was then regioselectively silylated at the primary position, furnishing rac-286. Sharpless asymmetric epoxidation with L-(+)-DIPT / Ti(O-i-Pr)4 afforded epoxy alcohol (3S)-295 with more than $99 \%$ ee and (3R)-296 with 91\% ee. Silylation of (3S)-295 gave the precursor epoxide (3S)-297 for the synthesis of maresin-L1, while (3R)-296 was converted to epoxide (3R)-298 using the D-(-)-DIPT/Ti(O-iPr)4, followed by silylation to furnish (3R)-297, the precursor for the preparation of maresin-L2. 


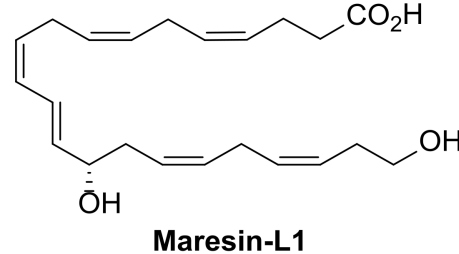

Maresin-L1

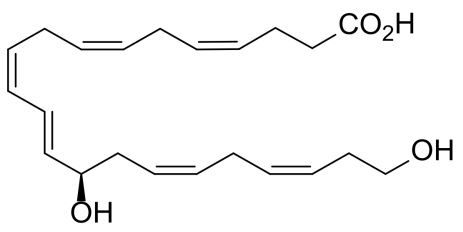

Maresin-L2

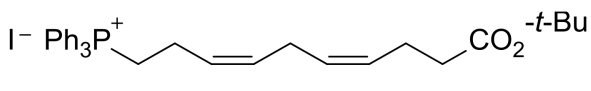

284<smiles>O=CC=CC([OH+])CC=CCC=CCC[OH2+]</smiles>

285<smiles>C=CC=CC(O)CC=CCC=CCCOCC</smiles>

286

Scheme 39. Structure of maresin-L1 and maresin-L2 and retrosynthesis of maresin-L1, as reported by Hong et al. [116].

\section{Synthesis of phosphonium salt 284}

$$
\mathrm{CH}_{3} \mathrm{CO}_{2} t \mathrm{Bu}
$$

287

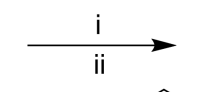

$$
\mathrm{Cl}
$$<smiles>CCC#CCCl</smiles><smiles>CCOCCCC#CCCl</smiles>

288

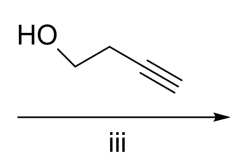

289

$\mathrm{HO}$

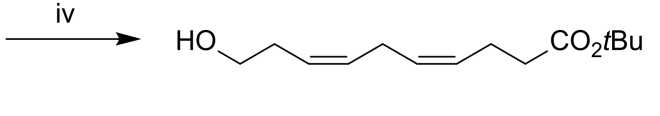

290

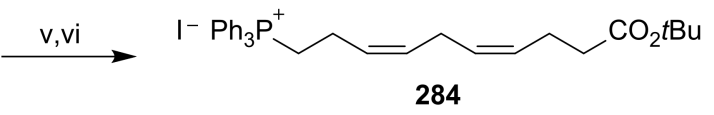

Scheme 40. Synthesis of phosphonium salt 284, as reported by Hong et al. [116]. Reagents and conditions: i. LDA (1.3 equiv.); ii. HMPA (1 equiv.), THF, $0{ }^{\circ} \mathrm{C}, 1 \mathrm{~h}$; iii. $\mathrm{CuI}$ (1.2 equiv.), NaI (1.2 equiv.), $\mathrm{Cs}_{2} \mathrm{CO}_{3}$ (1.2 equiv.), DMF, rt, overnight; iv. $\mathrm{H}_{2}, \mathrm{P}-2 \mathrm{Ni}$ (1.2 equiv.), $\left(\mathrm{H}_{2} \mathrm{NCH}_{2}\right)_{2}$ (2 equiv.), $\mathrm{MeOH}$, $0{ }^{\circ} \mathrm{C}, 4$ h, 80\%; v. $\mathrm{I}_{2}$ (1.4 equiv.), $\mathrm{PPh}_{3}$ (2.5 equiv.), imidazole (2.5 equiv.), $\mathrm{CH}_{2} \mathrm{Cl}_{2}, \mathrm{rt}, 1$ h; vi. $\mathrm{PPh}_{3}$ (1 equiv.), MeCN, $\triangle$, overnight, $88 \%$.

The synthesis of maresins was accomplished in five steps from the corresponding epoxides. For example, maresin-L1 was synthesized from (3S)-297, which reacted with diethylaluminum cyanide to afford nitrile 299 , which was reduced to aldehyde 285 by DIBAL. Wittig reaction with 284, desilylation with TBAF, and ester hydrolysis gave maresinL1 in 35.3\% overall yield from (3S)-297, Scheme 42. 


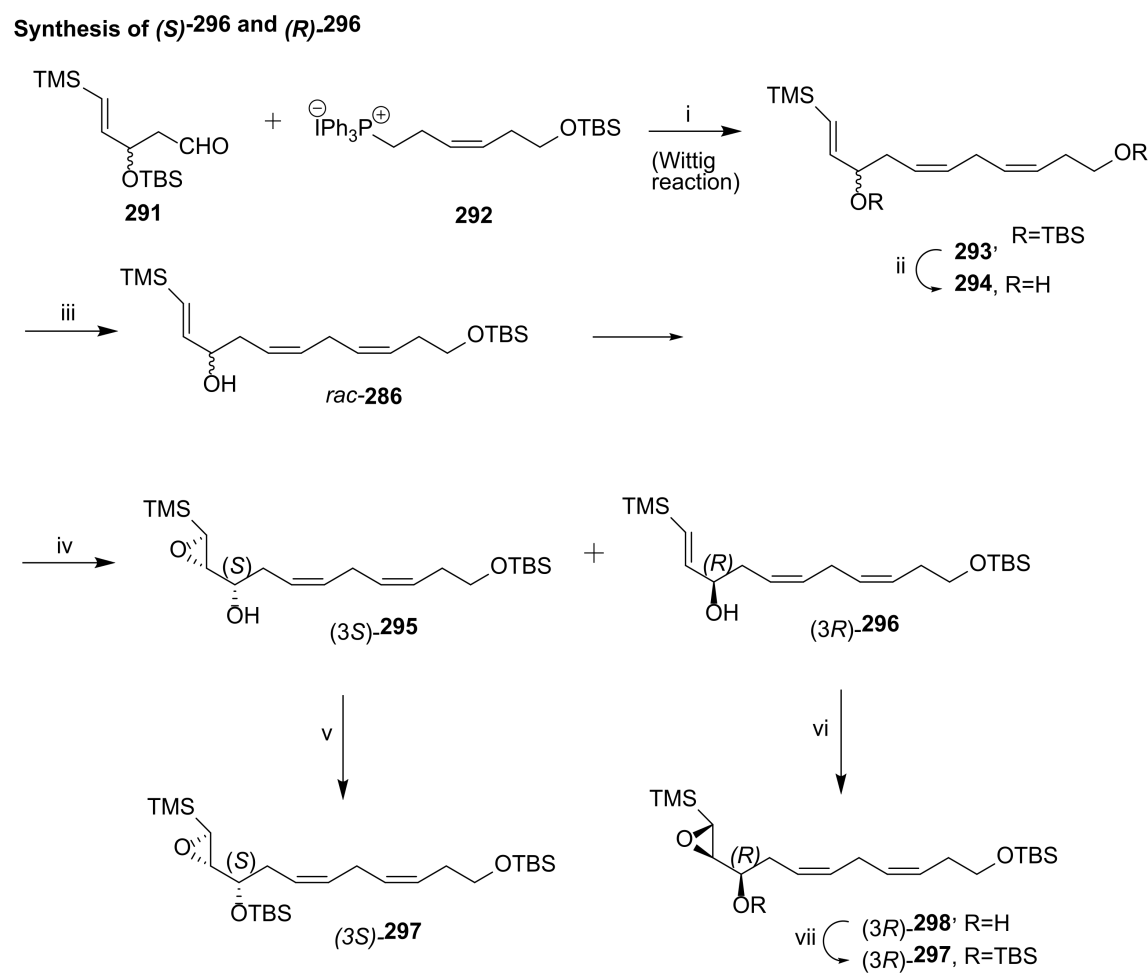

Scheme 41. Synthesis of (3S)- and (3R)-296, as reported by Hong et al. [116]. Reagents and conditions: i. 292 (1.1 equiv.), $\mathrm{NaN}$ (TMS) $)_{2}$ (1.0 equiv.), THF, $-78{ }^{\circ} \mathrm{C}, \mathrm{rt}, 15 \mathrm{~min}$; ii. $\mathrm{N}-\mathrm{Bu}_{4} \mathrm{NF}$ (6 equiv.), THF, rt, $3 \mathrm{~h}$; iii. TBSCl (2 equiv), imidazole (3 equiv), $\mathrm{CH}_{2} \mathrm{Cl}_{2}, \mathrm{rt}, 30 \mathrm{~min}$; iv. $t$ - $\mathrm{BuOOH}$ (1.5 equiv), $\mathrm{Ti}(\mathrm{O}-i-\mathrm{Pr})_{4}$ (1.0 equiv.), L-(+)-DIPT(1.2 equiv.), $\mathrm{CH}_{2} \mathrm{Cl}_{2},-18{ }^{\circ} \mathrm{C}, 5 \mathrm{~h}$; v. TBSOTf (1.5 equiv.), 2,6-lutidine (3 equiv.), $\mathrm{CH}_{2} \mathrm{Cl}_{2}, 10 \mathrm{~min}, 97 \%$; vi. $t \mathrm{BuOOH}$ (1.5 equiv.), Ti(O-i-Pr) $)_{4}(1.0$ equiv.), L-(+)-DIPT (1.2 equiv.), $\mathrm{CH}_{2} \mathrm{Cl}_{2},-18{ }^{\circ} \mathrm{C}, 3 \mathrm{~h}$; vii. TBSOTf, 2,6-lutidine, $\mathrm{CH}_{2} \mathrm{Cl}_{2}, 10 \mathrm{~min}, 97 \%$.

A. Synthesis of maresin-L1
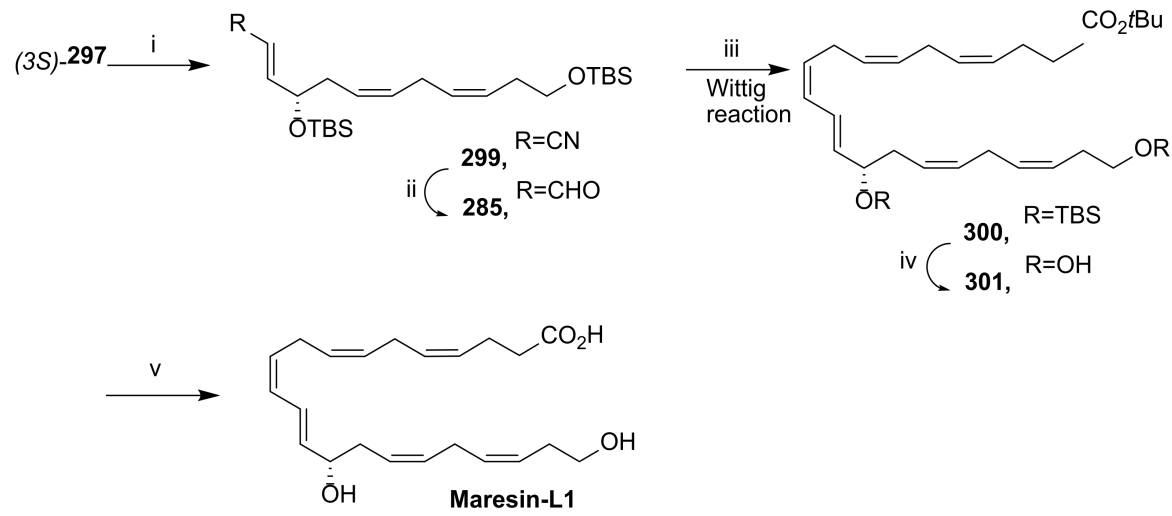

B. Synthesis of maresin-L2<smiles>CCCCCCCCCCC=CC=CCC(O)CC=CCC=CCCO</smiles>

Scheme 42. Synthesis of maresin-L1 and maresin-L2, as reported by Hong et al. [116]. Reagents and conditions: i. $\mathrm{Et}_{2} \mathrm{AICN}$ (7 equiv.), THF, rt, $15 \mathrm{~min}, 95 \%$; ii. DIBAL (2 equiv.), THF, $-78^{\circ} \mathrm{C}, \mathrm{rt}, 10 \mathrm{~min}$, $75 \%$; iii. 284 (2.8 equiv), $\mathrm{NaN}$ (TMS) 2 (2.7 equiv.), THF, $-90{ }^{\circ} \mathrm{C}$ to $0{ }^{\circ} \mathrm{C}, 10 \mathrm{~min}$; iv. TBAF (8 equiv.), 301 (84\%), THF, rt, 30 min; v. $\mathrm{LiOH}$ (30 equiv.), $\mathrm{MeOH} / \mathrm{H}_{2} \mathrm{O}$ (1:1), rt, 22 h, 59\%. 


\section{The New Coronavirus (SARS-CoV-2) and DHA-Derived SPMs}

The viral life cycle includes the various stages involved in viral replication that occur inside cells. Thus, it can include three stages: (1) entry, (2) genome replication, and (3) exit. Studies of SPMs as regulators of the inflammatory response caused by viral infections have been carried out, but the effect of SPM on the viral life cycle needs more research.

Coronavirus disease (COVID-19) is caused by the new virus SARS-CoV-2 (severe acute respiratory syndrome coronavirus), which emerged in 2019 in Wuhan (Hubei province in China) and was declared by WHO as a global epidemic. Among risk factors for SARS-CoV-2 infection, obesity contributes with more than $60 \%$ of incidence and seems to be related to a deficiency of SPMs [117].

The main symptoms of virus infection are headache, fever, fatigue, cough, and chest tightness, among others [118]. However, this virus can be more aggressive, provoking severe symptoms that include systemic inflammatory response, organ failure, and death [101]. So far, there is no treatment for COVID-19. However, the scientific community has been struggling to offer immune protection against this disease. This effort resulted in more than 300 vaccine projects, with some of them already approved, such as a Pfizer-BioNTech vaccine, produced in US, and an AstraZeneca vaccine, developed by the University of Oxford and produced in UK, Sweden, and Italy [119], among others.

COVID-19 severe cases are much more common in elderly people with other morbidities, such as diabetes, cardiovascular diseases, hypertension, and respiratory diseases [117]. SARS-CoV-2 is an RNA virus that infects the lungs and consequently cells of the immune system that try to react to the inflammation. Among the human body immune system responses to COVID-19, excessive stimulation of the inflammatory response can occur, which is called "cytokine storm", indicating a state of hyperinflammation and resulting in dysregulation of lipid transport. The DHA metabolites resolvins, protectins, and maresins behave as "turn off switch" in inflammatory processes and play an important role in viral infections [117]. The resolvins of D series, particularly D1, D2, D3, D4, and D5 and the intermediate 17HDHA may have a functional role as lipid mediators in the "cytokine storm" of SARS-CoV-2 infection, diminishing pro-inflammatory levels [120,121]. Moreover, RvD2 and MaR1 are described as block inflammasome components, leading to the reduction in IL-1 $\beta$ release, a potent pro-inflammatory cytokine [39].

It is known that DHA inactivates enveloped viruses and can inhibit proliferation of some microbial organisms [120,122]; as described by Torrinhas et al. [121], DHA supplementation can improve blood oxygenation in patients with acute respiratory distress syndrome, with a consequent reduction in ventilation requirement and length of stay in the ICU [105]. Additionally, patients receiving parenteral nutrition therapy fortified with lipid emulsion enriched in DHA were reported to have decreased infection and sepsis risk and a reduction in ICU stay of about 2 days [121]. Despite requiring further research, the consumption of DHA in the diet seems to help improve treatment and recovery of severe COVID-19, as DHA-SPMs are antiinflammation pro-resolving agents [123,124].

Another potential site for the entrance of SARS-CoV-2 in the human body is through the cornea, where the SARS-CoV-2 receptors are expressed, including ACE2 and host proteases for the S protein. Thus, recent studies [61] pointed out that DHA-SPMs such as RvD6 isomers and elovanoid N32 reduced the expression of angiotensin converting enzyme 2 (ACE2). On the other hand, NDP1 did not reduce it. RvD6 isomers and elovanoid N32 also counteract the binding of the receptor-binding domain of SARS-CoV-2 spike (S) protein to the injured cornea [125].

Further research is needed on the role of RvDs, PDs, and MaRs in SARsCOV-2 and the effect of DHA-SPM on the viral life cycle. Moreover, the interaction between the host immune system and infectious viral attack is also a very promising research area. Thus, the bioactivity of these lipid mediators will contribute to open therapeutic avenues to counteract virus attachment and entrance to the human body. 


\section{Conclusions}

This review summarizes current knowledge on DHA metabolites as anti-inflammatory lipid mediators with pro-resolving activity. DHA can be obtained essentially from marine sources and is available at sites of acute inflammation, where it is converted in diverse bioactive metabolites-namely, the SPM D-series resolvins, protectins, and maresins that act at subnanomolar doses. SPMs are produced in human body fluids and organs and are involved in the resolution of inflammation, wound healing, and neuroprotection, acting in neutrophils, macrophages, endothelial and epithelial cells, and lymphocytes. DHA-SPMs have several health benefits; in particular, D-resolvins were reported as neuroprotective agents, also acting against cell injury-induced oxidative stress as well as protectins. Maresins show action in nervous system diseases, and they have a powerful protective effect in inflammation, oxidative stress, immune diseases, and tissue regeneration. More recently, with the rise of COVID-19, DHA-SPM - mainly protectins and D-series resolvins-demonstrated relevant action, decreasing cytokine storm and consequently pro-inflammatory levels. In addition, the recently discovered interaction of RvD6 with the binding domain of SARS-CoV-2 spike protein is very promising and encourages further investigation in this area. Although DHA-SPMs structure and biosynthesis is already known, the access to these molecules is scarce from natural resources and by biosynthetic pathways. Their potent bioactivities encourage further investigation aiming at their valorisation for therapeutic purposes, but this research requires access to large amounts of the studied product. These issues motivated the scientific community to develop their total organic synthesis, illustrated in this review for DHA-SPMs. These anti-inflammatory lipid mediators are very complex molecules with defined stereochemistry. Indeed, the highly stereoselective and convergent approaches developed demonstrate the importance of organic chemistry in accessing these molecules towards development of new therapeutics against neurodegenerative diseases, coronary heart disease, cancer, diabetes, and viral infections, opening new avenues for COVID-19 therapy research.

Author Contributions: N.B. and A.P.R., conceptualization, and supervision; I.F. and F.F., writingoriginal draft preparation; I.F., N.B., and A.P.R., writing-review and editing; I.F. and A.P.R., the preparation of schemes and figures. All authors have read and agreed to the published version of the manuscript.

Funding: This research was funded by FUNDAÇÃO PARA A CIÊNCIA E A TECNOLOGIA, projects UIDB/00100/2020, UIDP/CVT/00276/2020, PTDC/SAUNUT/30455/2017, and the grant 2021.06108.BD

Institutional Review Board Statement: Not applicable.

Informed Consent Statement: Not applicable.

Data Availability Statement: Not applicable.

Acknowledgments: The authors are grateful to Fundação para a Ciência e a Tecnologia (FCT) for the financial support to Centro de Química Estrutural (project UIDB/00100/2020), CIIMAR (UIDP/CVT/00276/2020), the project PTDC/SAUNUT/30455/2017 and the grant 2021.06108.BD.

Conflicts of Interest: The authors declare no conflict of interest.

\section{References}

1. Aneiros, A.; Garateix, A. Bioactive peptides from marine sources: Pharmacological properties and isolation procedures. J. Chromatogr. B Anal. Technol. Biomed. Life Sci. 2004, 803, 41-53. [CrossRef] [PubMed]

2. Petersen, L.-E.; Kellermann, M.Y.; Schupp, P.J. Secondary Metabolites of Marine Microbes: From Natural Products Chemistry to Chemical Ecology. YOUMARES 2020, 9, 159-180.

3. Blunt, J.W.; Copp, B.R.; Keyzers, R.A.; Munro, M.H.G.; Prinsep, M.R. Marine natural products. Nat. Prod. Rep. 2017, 34, 235-294. [CrossRef] [PubMed]

4. Gallimore, W. Marine Metabolites: Oceans of Opportunity. Pharmacogn. Fundam. Appl. Strategy 2017, 377-400. [CrossRef]

5. Barzkar, N.; Jahromi, S.T.; Poorsaheli, H.B.; Vianello, F. Metabolites from marine microorganisms, micro, and macroalgae: Immense scope for pharmacology. Mar. Drugs 2019, 17, 464. [CrossRef] [PubMed] 
6. Hamed, I.; Özogul, F.; Özogul, Y.; Regenstein, J.M. Marine Bioactive Compounds and Their Health Benefits: A Review. Compr. Rev. Food Sci. Food Saf. 2015, 14, 446-465. [CrossRef]

7. Zhang, G.; Panigrahy, D.; Mahakian, L.M.; Yang, J.; Liu, J.Y.; Lee, K.S.; Wettersten, H.I.; Ulu, A.; Hu, X.; Tam, S.; et al. Epoxy metabolites of docosahexaenoic acid (DHA) inhibit angiogenesis, tumor growth, and metastasis. Proc. Natl. Acad. Sci. USA 2013, 110, 6530-6535. [CrossRef]

8. Mori, T.A.; Beilin, L.J. Omega-3 fatty acids and inflammation. Curr. Atheroscler. Rep. 2004, 6, 461-467. [CrossRef]

9. Oleñik, A.; Mahillo-Fernández, I.; Alejandre-Alba, N.; Fernández-Sanz, G.; Alarcón Pérez, M.; Luxan, S.; Quintana, S.; Martínez de Carneros Llorente, A.; García-Sandoval, B.; Jiménez-Alfaro, I. Benefits of omega-3 fatty acid dietary supplementation on health-related quality of life in patients with meibomian gland dysfunction. Clin. Ophthalmol. 2014, 8, 831-836. [CrossRef]

10. Innes, J.K.; Calder, P.C. Marine omega-3 (N-3) fatty acids for cardiovascular health: An update for 2020. Int. J. Mol. Sci. 2020, 21, 1362. [CrossRef]

11. Avallone, R.; Vitale, G.; Bertolotti, M. Omega-3 fatty acids and neurodegenerative diseases: New evidence in clinical trials. Int. J. Mol. Sci. 2019, 20, 4256. [CrossRef]

12. Tur, J.A.; Bibiloni, M.M.; Sureda, A.; Pons, A. Dietary sources of omega 3 fatty acids: Public health risks and benefits. Br. J. Nutr. 2012, 107, S23-S52. [CrossRef] [PubMed]

13. Calder, P.C. Omega-3 fatty acids and inflammatory processes. Nutrients 2010, 2, 355-374. [CrossRef]

14. Cardoso, C.; Afonso, C.; Bandarra, N.M. Dietary DHA, bioaccessibility, and neurobehavioral development in children. Crit. Rev. Food Sci. Nutr. 2018, 58, 2617-2631. [CrossRef] [PubMed]

15. Bandarra, N.M.; Batista, I.; Nunes, M.L.; Empis, J.M.; Christie, W.W. Seasonal changes in lipid composition of sardine (Sardina pilchardus). J. Food Sci. 1997, 62, 40-42. [CrossRef]

16. Ferreira, I.; Gomes-Bispo, A.; Lourenço, H.; Matos, J.; Afonso, C.; Cardoso, C.; Castanheira, I.; Motta, C.; Prates, J.A.M.; Bandarra, N.M. The chemical composition and lipid profile of the chub mackerel (Scomber colias) show a strong seasonal dependence: Contribution to a nutritional evaluation. Biochimie 2020, 178, 181-189. [CrossRef] [PubMed]

17. Welch, A.A.; Shakya-Shrestha, S.; Lentjes MA, H.; Wareham, N.J.; Khaw, K.T. Dietary intake and status of n-3 polyunsaturated fatty acids in a population of fish-eating and non-fish-eating meat-eaters, vegetarians, and vegans and the precursor-product ratio of $\alpha$-linolenic acid to long-chain n-3 polyunsaturated fatty acids: Results. Am. J. Clin. Nutr. 2010, 92, 1040-1051. [CrossRef]

18. Cardoso, C.; Afonso, C.; Bandarra, N.M. Dietary DHA and health: Cognitive function ageing. Nutr. Res. Rev. 2016, 29, 281-294. [CrossRef]

19. Calder, P.C. Docosahexaenoic acid. Ann. Nutr. Metab. 2016, 69, 8-21. [CrossRef]

20. Kuratko, C.N.; Barrett, E.C.; Nelson, E.B.; Salem, N. The relationship of docosahexaenoic acid (DHA) with learning and behavior in healthy children: A review. Nutrients 2013, 5, 2777-2810. [CrossRef]

21. Martins, B.P.; Bandarra, N.M.; Figueiredo-Braga, M. The role of marine omega-3 in human neurodevelopment, including Autism Spectrum Disorders and Attention-Deficit/Hyperactivity Disorder-a review. Crit. Rev. Food Sci. Nutr. 2020, 60, 1431-1446. [CrossRef]

22. Nguyen, Q.V.; Malau-Aduli, B.S.; John, C.; Nichols, P.D.; Malau-Aduli, E.O. Enhancing Omega-3 Long-Chain Polyunsaturated Human Consumption. Nutrients 2019, 743, 1-23.

23. Kwon, Y. Immuno-Resolving Ability of Resolvins, Protectins, and Maresins Derived from Omega-3 Fatty Acids in Metabolic Syndrome. Mol. Nutr. Food Res. 2020, 64, 1-12. [CrossRef]

24. Kuda, O. Bioactive metabolites of docosahexaenoic acid. Biochimie 2017, 136, 12-20. [CrossRef]

25. Jaén, R.I.; Sánchez-García, S.; Fernández-Velasco, M.; Boscá, L.; Prieto, P. Resolution-Based Therapies: The Potential of Lipoxins to Treat Human Diseases. Front. Immunol. 2021, 12, 1-14. [CrossRef] [PubMed]

26. Duvall, M.G.; Levy, B.D. DHA- and EPA-derived resolvins, protectins, and maresins in airway inflammation. Eur. J. Pharmacol. 2016, 785, 144-155. [CrossRef] [PubMed]

27. Serhan, C.N.; Levy, B.D. Resolvins in inflammation: Emergence of the pro-resolving superfamily of mediators. J. Clin. Investig. 2018, 128, 2657-2669. [CrossRef]

28. Tungen, J.E.; Aursnes, M.; Hansen, T.V. Stereoselective synthesis of maresin 1. Tetrahedron Lett. 2015, 56, 1843-1846. [CrossRef]

29. Serhan, C.N.; Petasis, N.A. Resolvins and protectins in inflammation resolution. Chem. Rev. 2011, 111, 5922-5943. [CrossRef]

30. Malawista, S.E.; Chevance AD, B.; Van Damme, J.; Serhan, C.N. Tonic inhibition of chemotaxis in human plasma. Proc. Natl. Acad. Sci. USA 2008, 105, 17949-17954. [CrossRef]

31. Gordon, S. Phagocytosis: An Immunobiologic Process. Immunity 2016, 44, 463-475. [CrossRef] [PubMed]

32. Serhan, C.N.; Chiang, N. Resolution phase lipid mediators of inflammation: Agonists of resolution. Curr. Opin. Pharmacol. 2013, 13, 1-9. [CrossRef] [PubMed]

33. Serhan, C.N. Treating inflammation and infection in the 21st century: New hints from decoding resolution mediators and mechanisms. FASEB J. 2017, 31, 1273-1288. [CrossRef] [PubMed]

34. Serhan, C.N. Pro-resolving lipid mediators are leads for resolution physiology. Nature 2014, 510, 92-101. [CrossRef] [PubMed]

35. Li, C.; Wu, X.; Liu, S.; Shen, D.; Zhu, J.; Liu, K. Role of Resolvins in the Inflammatory Resolution of Neurological Diseases. Front. Pharmacol. 2020, 11, 612. [CrossRef] 
36. Serhan, C.N.; Hong, S.; Gronert, K.; Colgan, S.P.; Devchand, P.R.; Mirick, G.; Moussignac, R.-L. Resolvins: A family of bioactive products of omega-3 fatty acid transformation circuits initiated by aspirin treatment that counter proinflammation signals. J. Exp. Med. 2002, 196, 1025-1037. [CrossRef] [PubMed]

37. Serhan, C.N.; Dalli, J.; Karamnov, S.; Choi, A.; Park, C.; Xu, Z.; Ji, R.; Zhu, M.; Petasis, N.A. Macrophage proresolving mediator maresin 1 stimulates tissue regeneration and controls pain. FASEB J. 2012, 26, 1755-1765. [CrossRef]

38. Mukherjee, P.K.; Marcheselli, V.L.; Serhan, C.N.; Bazan, N.G. Neuroprotectin D1: A docosahexaenoic acid-derived docosatriene protects human retinal pigment epithelial cells from oxidative stress. Proc. Natl. Acad. Sci. USA 2004, 101, 8491-8496. [CrossRef]

39. Chiang, N.; Serha, C.N. Specialized pro-resolving mediator network: An update on production and actions. Essays Biochem. 2020, 64, 443-462.

40. Han, Y.H.; Lee, K.; Saha, A.; Han, J.; Choi, H.; Noh, M.; Lee, Y.H.; Lee, M.O. Specialized proresolving mediators for therapeutic interventions targeting metabolic and inflammatory disorders. Biomol. Ther. 2021, 29, 455-464. [CrossRef]

41. Ariyoshi, T.; Hagihara, M.; Eguchi, S.; Fukuda, A.; Iwasaki, K.; Oka, K.; Takahashi, M.; Yamagishi, Y.; Mikamo, H. Clostridium butyricum MIYAIRI 588-Induced Protectin D1 Has an Anti-inflammatory Effect on Antibiotic-Induced Intestinal Disorder. Front. Microbiol. 2020, 11, 2789. [CrossRef] [PubMed]

42. Duffield, J.S.; Hong, S.; Vaidya, V.S.; Lu, Y.; Fredman, G.; Serhan, C.N.; Bonventre, J.V. Resolvin D Series and Protectin D1 Mitigate Acute Kidney Injury. J. Immunol. 2006, 177, 5902-5911. [CrossRef] [PubMed]

43. Kohli, P.; Levy, B.D. Resolvins and protectins: Mediating solutions to inflammation. Br. J. Pharmacol. 2009, 158, 960-971. [CrossRef]

44. Miyahara, T.; Runge, S.; Chatterjee, A.; Chen, M.; Mottola, G.; Fitzgerald, J.M.; Serhan, C.N.; Conte, M.S. D-series resolvin attenuates vascular smooth muscle cell activation and neointimal hyperplasia following vascular injury. FASEB J. 2013, 27, 2220-2232. [CrossRef] [PubMed]

45. Mizwicki, M.T.; Liu, G.; Fiala, M.; Magpantay, L.; Sayre, J.; Siani, A.; Mahanian, M.; Weitzman, R.; Hayden, E.Y.; Rosenthal, M.J.; et al. $1 \alpha, 25$-dihydroxyvitamin D3 and resolvin D1 retune the balance between amyloid- $\beta$ phagocytosis and inflammation in Alzheimer's disease patients. J. Alzheimer's Dis. 2013, 34, 155-170. [CrossRef] [PubMed]

46. Xu, Z.Z.; Zhang, L.; Liu, T.; Park, J.Y.; Berta, T.; Yang, R.; Serhan, C.N.; Ji, R.R. Resolvins RvE1 and RvD1 attenuate inflammatory pain via central and peripheral actions. Nat. Med. 2010, 16, 592-597. [CrossRef]

47. Bang, S.; Yoo, S.; Yang, T.J.; Cho, H.; Hwang, S. 17(R)-resolvin D1 specifically inhibits transient receptor potential ion channel vanilloid 3 leading to peripheral antinociception. Br. J. Pharmacol. 2012, 165, 683-692. [CrossRef]

48. Serhan, C.N.; Chiang, N.; Dalli, J.; Levy, B.D.; Tracey, K.J.; Serhan, C.N.; Chiang, N.; Dalli, J.; De Zoete, M.R.; Palm, N.W.; et al. Lipid mediators in the resolution of inflammation. Cold Spring Harb. Perspect. Biol. 2014, 7, a016311. [CrossRef]

49. Lima-Garcia, J.F.; Dutra, R.C.; Silva, D.A.; Motta, E.M.; Campos, M.M.; Calixto, J.B. The precursor of resolvin D series and aspirin-triggered resolvin D1 display anti-hyperalgesic properties in adjuvant-induced arthritis in rats. Br. J. Pharmacol. 2011, 164, 278-293. [CrossRef]

50. Klein, C.P.; Sperotto ND, M.; Maciel, I.S.; Leite, C.E.; Souza, A.H.; Campos, M.M. Effects of D-series resolvins on behavioral and neurochemical changes in a fibromyalgia-like model in mice. Neuropharmacology 2014, 86, 57-66. [CrossRef]

51. Terrando, N.; Gómez-Galán, M.; Yang, T.; Carlström, M.; Gustavsson, D.; Harding, R.E.; Lindskog, M.; Eriksson, L.I. Aspirintriggered resolvin D1 prevents surgery-induced cognitive decline. FASEB J. 2013, 27, 3564-3571. [CrossRef] [PubMed]

52. Marcheselli, V.L.; Hong, S.; Lukiw, W.J.; Tian, X.H.; Gronert, K.; Musto, A.; Hardy, M.; Gimenez, J.M.; Chiang, N.; Serhan, C.N.; et al. Novel Docosanoids Inhibit Brain Ischemia-Reperfusion-mediated Leukocyte Infiltration and Pro-inflammatory Gene Expression. J. Biol. Chem. 2003, 278, 43807-43817. [CrossRef] [PubMed]

53. Ariel, A.; Fredman, G.; Sun, Y.P.; Kantarci, A.; Dyke TE, V.a.n.; Luster, A.D.; Serhan, C.N. Apoptotic neutrophils and T cells sequester chemokines during immune response resolution through modulation of CCR5 expression. Nat. Immunol. 2006, 7, 1209-1216. [CrossRef] [PubMed]

54. Schwab, J.M.; Chiang, N.; Arita, M.; Serhan, C.N. Resolvin E1 and protectin D1 activate inflammation-resolution programmes. Nature 2007, 447, 869-874. [CrossRef]

55. Ariel, A.; Li, P.L.; Wang, W.; Tang, W.X.; Fredman, G.; Hong, S.; Gotlinger, K.H.; Serhan, C.N. The docosatriene protectin D1 is produced by TH2 skewing promotes human T cell via lipid raft clustering. J. Biol. Chem. 2005, 280, 43079-43086. [CrossRef]

56. Hong, S.; Gronert, K.; Devchand, P.R.; Moussignac, R.L.; Serhan, C.N. Novel docosatrienes and 17S-resolvins generated from docosahexaenoic acid in murine brain, human blood, and glial cells: Autacoids in anti-inflammation. J. Biol. Chem. 2003, 278, 14677-14687. [CrossRef]

57. Levy, B.D.; Kohli, P.; Gotlinger, K.; Haworth, O.; Hong, S.; Kazani, S.; Israel, E.; Haley, K.J.; Serhan, C.N. Protectin D1 Is Generated in Asthma and Dampens Airway Inflammation and Hyperresponsiveness. J. Immunol. 2007, 178, 496-502. [CrossRef]

58. Tian, Y.; Zhang, Y.; Zhang, R.; Qiao, S.; Fan, J. Resolvin D2 recovers neural injury by suppressing inflammatory mediators expression in lipopolysaccharide-induced Parkinson's disease rat model. Biochem. Biophys. Res. Commun. 2015, 460, 799-805. [CrossRef]

59. Dalli, J.; Winkler, J.W.; Colas, R.A.; Arnardottir, H.; Cheng CY, C.; Chiang, N.; Petasis, N.A.; Serhan, C.N. Resolvin D3 and aspirin-triggered resolvin D3 are potent immunoresolvents. Chem. Biol. 2013, 20, 188-201. [CrossRef]

60. Winkler, J.W.; Orr, S.K.; Dalli, J.; Cheng, C.Y.; Sanger, J.M.; Chiang, N.; Petasis, N.A.; Serhan, C.N. Resolvin D4 stereoassignment and its novel actions in host protection and bacterial clearance. Sci. Rep. 2016, 6, 18972. [CrossRef] 
61. Pham, T.L.; Kakazu, A.H.; He, J.; Nshimiyimana, R.; Petasis, N.A.; Jun, B.; Bazan, N.G.; Bazan HE, P. Elucidating the structure and functions of Resolvin D6 isomers on nerve regeneration with a distinctive trigeminal transcriptome. FASEB J. 2021, 35, e21775. [CrossRef] [PubMed]

62. Hwang, S.M.; Chung, G.; Kim, Y.H.; Park, C.K. The role of maresins in inflammatory pain: Function of macrophages in wound regeneration. Int. J. Mol. Sci. 2019, 20, 5849. [CrossRef] [PubMed]

63. Francos-Quijorna, I.; Santos-Nogueira, E.; Gronert, K.; Sullivan, A.B.; Kopp, M.A.; Brommer, B.; David, S.; Schwab, J.M.; LópezVales, R. Maresin 1 promotes inflammatory resolution, neuroprotection, and functional neurological recovery after spinal cord injury. J. Neurosci. 2017, 37, 11731-11743. [CrossRef] [PubMed]

64. Rodriguez, A.R.; Spur, B.W. First total synthesis of the macrophage derived anti-inflammatory and pro-resolving lipid mediator Maresin 2. Tetrahedron Lett. 2015, 56, 256-259. [CrossRef]

65. Dangi, B.; Obeng, M.; Nauroth, J.M.; Teymourlouei, M.; Needham, M.; Raman, K.; Arterburn, L.M. Biogenic synthesis, purification, and chemical characterization of anti-inflammatory resolvins derived from docosapentaenoic acid (DPAn-6). J. Biol. Chem. 2009, 284, 14744-14759. [CrossRef]

66. Oh, S.F.; Vickery, T.; Schmidt, B.A.; Serhan, C.N.; Chiang, N.; Fredman, G.; Ba, F. Infection regulates pro-resolving mediators that lower antibiotic requirements. Nature 2012, 484, 524-529.

67. Oh, S.F.; Pillai, P.S.; Recchiuti, A.; Yang, R.; Serhan, C.N. Pro-resolving actions and stereoselective biosynthesis of $18 \mathrm{~S}$ E-series resolvins in human leukocytes and murine inflammation. J. Clin. Investig. 2011, 121, 569-581. [CrossRef]

68. Hong, S.; Lu, Y.; Yang, R.; Gotlinger, K.H.; Petasis, N.A.; Serhan, C.N. Resolvin D1, Protectin D1, and related docosahexaenoic acid-derived products: Analysis via electrospray/low energy tandem mass spectrometry based on spectra and fragmentation mechanisms. J. Am. Soc. Mass Spectrom. 2007, 18, 128-144. [CrossRef]

69. Bazan, N.G. Neuroprotectin D1 (NPD1): A DHA-derived mediator that protects brain and retina against cell injury-induced oxidative stress. Brain Pathol. 2005, 15, 159-166. [CrossRef]

70. Chiang, N.; Serhan, C.N. Structural elucidation and physiologic functions of specialized pro-resolving mediators and their receptors. Mol. Asp. Med. 2017, 58, 114-129. [CrossRef]

71. Brennan, E.; Kantharidis, P.; Cooper, M.E. Pro-resolving lipid mediators: Regulators of inflammation, metabolism and kidney function. Nat. Rev. Nephrol. 2021, 17, 725-739. [CrossRef] [PubMed]

72. Chen, J.; Shetty, S.; Zhang, P.; Gao, R.; Hu, Y.; Wang, S.; Li, Z.; Fu, J. Aspirin-triggered resolvin D1 down-regulates inflammatory responses and protects against endotoxin-induced acute kidney injury. Toxicol. Appl. Pharmacol. 2014, 277, 118-123. [CrossRef] [PubMed]

73. Luan, H.; Wang, C.; Sun, J.; Zhao, L.; Li, L.; Zhou, B.; Shao, S.; Shen, X.; Xu, Y. Resolvin D1 Protects Against Ischemia/ReperfusionInduced Acute Kidney Injury by Increasing Treg Percentages via the ALX/FPR2 Pathway. Front. Physiol. 2020, 11, 285. [CrossRef] [PubMed]

74. Qu, X.; Zhang, X.; Yao, J.; Song, J.; Nikolic-Paterson, D.J.; Li, J. Resolvins E1 and D1 inhibit interstitial fibrosis in the obstructed kidney via inhibition of local fibroblast proliferation. J. Pathol. 2012, 228, 506-519. [CrossRef] [PubMed]

75. Sulciner, M.L.; Serhan, C.N.; Gilligan, M.M.; Mudge, D.K.; Chang, J.; Gartung, A.; Lehner, K.A.; Bielenberg, D.R.; Schmidt, B.; Dalli, J.; et al. Resolvins suppress tumor growth and enhance cancer therapy. J. Exp. Med. 2018, 215, 115-140. [CrossRef]

76. Videla, L.A.; Vargas, R.; Valenzuela, R.; Muñoz, P.; Corbari, A.; Hernandez-Rodas, M.C. Combined administration of docosahexaenoic acid and thyroid hormone synergistically enhances rat liver levels of resolvins RvD1 and RvD2. Prostaglandins Leukot. Essent. Fat. Acids 2019, 140, 42-46. [CrossRef]

77. Hansen, T.V.; Vik, A.; Serhan, C.N. The protectin family of specialized pro-resolving mediators: Potent immunoresolvents enabling innovative approaches to target obesity and diabetes. Front. Pharmacol. 2019, 9, 1582. [CrossRef] [PubMed]

78. Gilligan, M.M.; Gartung, A.; Sulciner, M.L.; Norris, P.C.; Sukhatme, V.P.; Bielenberg, D.R.; Huang, S.; Kieran, M.W.; Serhan, C.N.; Panigrahy, D. Aspirin-triggered proresolving mediators stimulate resolution in cancer. Proc. Natl. Acad. Sci. USA 2019, 116, 6292-6297. [CrossRef]

79. Sun, Y.P.; Oh, S.F.; Uddin, J.; Yang, R.; Gotlinger, K.; Campbell, E.; Colgan, S.P.; Petasis, N.A.; Serhan, C.N. Resolvin D1 and its aspirin-triggered 17R epimer: Stereochemical assignments, anti-inflammatory properties, and enzymatic inactivation. J. Biol. Chem. 2007, 282, 9323-9334. [CrossRef]

80. Rodriguez, A.R.; Spur, B.W. Total synthesis of Resolvin D1, a potent anti-inflammatory lipid mediator. Tetrahedron Lett. 2012, 53, 6990-6994. [CrossRef]

81. Morita, M.; Wu, S.; Kobayashi, Y. Stereocontrolled synthesis of resolvin D1. Org. Biomol. Chem. 2019, 17, 2212-2222. [CrossRef]

82. Colvin, W.; Hamill, J. One- step Conversion of Carbonyl Compounds into Acetylenes By ERNEST. Chem. Commun. 1973, 5, 151-152. [CrossRef]

83. Kazuhiro Miwa, T.A.T.S. Extension of the colvin rearrangement using trimethylsilyldiazomethane. A new synthesis of alkynes. Synlett 1993, 1994, 107-108. [CrossRef]

84. Huang, Z.; Negishi, E.I. A convenient and genuine equivalent to $\mathrm{HZrCp} 2 \mathrm{Cl}$ generated in situ from ZrCp2Cl2-DIBAL-H. Org. Lett. 2006, 8, 3675-3678. [CrossRef] [PubMed]

85. Rodríguez, A.R.; Spur, B.W. First total synthesis of 7(S),16(R),17(S)-Resolvin D2, a potent anti-inflammatory lipid mediator. Tetrahedron Lett. 2004, 45, 8717-8720. [CrossRef] 
86. Li, J.; Leong, M.M.; Stewart, A.; Rizzacasa, M.A. Total synthesis of the endogenous inflammation resolving lipid resolvin D2 using a common lynchpin. Beilstein J. Org. Chem. 2013, 9, 2762-2766. [CrossRef]

87. Rodríguez, A.; Nomen, M.; Spur, B.W.; Godfroid, J.J. Selective oxidation of primary silyl ethers and its application to the synthesis of natural products. Tetrahedron Lett. 1999, 40, 5161-5164. [CrossRef]

88. Urbitsch, F.; Elbert, B.L.; Llaveria, J.; Streatfeild, P.E.; Anderson, E.A. A Modular, Enantioselective Synthesis of Resolvins D3, E1, and Hybrids. Org. Lett. 2020, 22, 1510-1515. [CrossRef]

89. Soullez, D.; Plé, G.; Duhamel, L. $\omega$-Halogeno polyenals: Preparation and application to a one-pot synthesis of polyenals from carbonyl compounds. J. Chem. Soc. Perkin Trans. 1997, 1, 1639-1645. [CrossRef]

90. Winkler, J.W.; Libreros, S.; La Rosa, X.D.e.; Sansbury, B.E.; Norris, P.C.; Chiang, N.; Fichtner, D.; Keyes, G.S.; Wourms, N.; Spite, M.; et al. Frontline Science: Structural insights into Resolvin D4 actions and further metabolites via a new total organic synthesis and validation. J. Leukoc. Biol. 2018, 103, 995-1010. [CrossRef]

91. Spur, B.W.; Rodr1, A.R. First total synthesis of 7(S), 17(S)-Resolvin D5, a potent anti-inflammatory docosanoid. Tetrahedron Lett. 2005, 46, 3623-3627.

92. Takai, K.; Nitta, K.; Utimoto, K. Simple and selective method for aldehydes (RCHO). fwdarw. (E)-haloalkenes (RCH:CHX) conversion by means of a haloform-chromous chloride system. J. Am. Chem. Soc. 1986, 108, 7408-7410. [CrossRef]

93. Ogawa, N.; Sugiyama, T.; Morita, M.; Suganuma, Y.; Kobayashi, Y. Total Synthesis of Resolvin D5. J. Org. Chem. 2017, 82, 2032-2039. [CrossRef] [PubMed]

94. Rodriguez, A.R.; Spur, B.W. First total synthesis of the anti-inflammatory lipid mediator Resolvin D6. Tetrahedron Lett. 2012, 53, 86-89. [CrossRef]

95. Morita, M.; Tanabe, S.; Arai, T.; Kobayashi, Y. Synthesis of Resolvin D6 and the Silyl Ether of the Resolvin E2 Methyl Ester via trans -Enynyl Alcohols. Synlett 2019, 30, 1351-1355. [CrossRef]

96. Labarre-Lainé, J.; Beniazza, R.; Desvergnes, V.; Landais, Y. Convergent access to bis-spiroacetals through a sila-Stetter-ketalization cascade. Org. Lett. 2013, 15, 4706-4709. [CrossRef]

97. Matsumura, K.; Hashiguchi, S.; Ikariya, T.; Noyori, R. The first asymmetric transfer hydrogenation of acetylenic ketones using chiral $\mathrm{Ru}$ (II) catalysts and 2-propanol as the hydrogen donor. 9 This method allows highly selective reduction of structurally diverse acetylenic ketones to propargylic alcohols of. J. Am. Chem. Soc. 1997, 119, 8738-8739. [CrossRef]

98. Aursnes, M.; Tungen, J.E.; Vik, A.; Colas, R.; Cheng, C.C.; Dalli, J.; Serhan, C.N.; Hansen, T. V Total Synthesis of the Lipid Mediator PD1. J. Nat. Prod. 2015, 77, 910-916. [CrossRef]

99. Asatryan, A.; Bazan, N.G. Molecular mechanisms of signaling via the docosanoid neuroprotectin D1 for cellular homeostasis and neuroprotection. J. Biol. Chem. 2017, 292, 12390-12397. [CrossRef]

100. Marcheselli, V.L.; Mukherjee, P.K.; Arita, M.; Hong, S.; Antony, R.; Sheets, K.; Winkler, J.W.; Petasis, N.A.; Serhan, C.N.; Bazan, N.G. Neuroprotectin D1/protectin D1 stereoselective and specific binding with human retinal pigment epithelial cells and neutrophils. Prostaglandins Leukot. Essent. Fat. Acids 2010, 82, 27-34. [CrossRef]

101. Bazan, N.G.; Calandria, J.M.; Serhan, C.N. Rescue and repair during photoreceptor cell renewal mediated by docosahexaenoic acid-derived neuroprotectin D1. J. Lipid Res. 2010, 51, 2018-2031. [CrossRef] [PubMed]

102. Singh, N.K.; Rao, G.N. Emerging role of 12/15-Lipoxygenase (ALOX15) in human pathologies. Prog. Lipid Res. 2019, 73, 28-45. [CrossRef] [PubMed]

103. González-Périz, A.; Horrillo, R.; Ferré, N.; Gronert, K.; Dong, B.; Morán-Salvador, E.; Titos, E.; Martínez-Clemente, M.; LópezParra, M.; Arroyo, V.; et al. Obesity-induced insulin resistance and hepatic steatosis are alleviated by $\omega-3$ fatty acids: A role for resolvins and protectins. FASEB J. 2009, 23, 1946-1957. [CrossRef] [PubMed]

104. Clària, J.; López-Vicario, C.; Rius, B.; Titos, E. Pro-resolving actions of SPM in adipose tissue biology. Mol. Asp. Med. 2017, 58, 83-92. [CrossRef]

105. Ogawa, N.; Kobayashi, Y. Total synthesis of the antiinflammatory and proresolving protectin D1. Tetrahedron Lett. 2011, 52, 3001-3004. [CrossRef]

106. Petasis, N.A.; Yang, R.; Winkler, J.W.; Zhu, M.; Uddin, J.; Bazan, N.G.; Serhan, C.N. Stereocontrolled total synthesis of Neuroprotectin D1/Protectin D1 and its aspirin-triggered stereoisomer. Tetrahedron Lett. 2012, 53, 1695-1698. [CrossRef]

107. Rodriguez, A.R.; Spur, B.W. Total synthesis of the potent anti-inflammatory lipid mediator Protectin D1. Tetrahedron Lett. 2014, 55, 6011-6015. [CrossRef]

108. Balas, L.; Risé, P.; Gandrath, D.; Rovati, G.; Bolego, C.; Stellari, F.; Trenti, A.; Buccellati, C.; Durand, T.; Sala, A. Rapid Metabolization of Protectin D1 by $\beta$-Oxidation of Its Polar Head Chain. J. Med. Chem. 2019, 62, 9961-9975. [CrossRef]

109. Müller, S.; Liepold, B.; Gerald, J.; Roth, H.J.B. An Improved One-pot Procedure for the Synthesis of Alkynes from Aldehydes. Synlett 1996, 521-522. [CrossRef]

110. Dayaker, G.; Durand, T.; Balas, L. A versatile and stereocontrolled total synthesis of dihydroxylated docosatrienes containing a conjugated E,E,Z-triene. Chem. Eur. J. 2014, 20, 2879-2887. [CrossRef]

111. Li, Q.F.; Hao, H.; Tu, W.S.; Guo, N.; Zhou, X.Y. Maresins: Anti-inflammatory pro-resolving mediators with therapeutic potential. Eur. Rev. Med. Pharmacol. Sci. 2020, 24, 7442-7453. [PubMed]

112. Sasaki, K.; Urabe, D.; Arai, H.; Arita, M.; Inoue, M. Total synthesis and bioactivities of two proposed structures of maresin. Chem. Asian J. 2011, 6, 534-543. [CrossRef] [PubMed] 
113. Rodriguez, A.R.; Spur, B.W. Total synthesis of the macrophage derived anti-inflammatory lipid mediator Maresin 1. Tetrahedron Lett. 2012, 53, 4169-4172. [CrossRef]

114. Dess, D.B.; Martin, J.C. A Useful 12-I-5 Triacetoxyperiodinane (the Dess-Martin Periodinane) for the Selective Oxidation of Primary or Secondary Alcohols and a Variety of Related 12-I-5 Species. J. Am. Chem. Soc. 1991, 113, 7277-7287. [CrossRef]

115. Hong, S.; Lu, Y.; Tian, H.; Alapure, B.V.; Wang, Q.; Bunnell, B.A.; Laborde, J.M. Maresin-like lipid mediators are produced by leukocytes and platelets and rescue reparative function of diabetes-impaired macrophages. Chem. Biol. 2014, 21, 1318-1329. [CrossRef]

116. Hong, S.; Lu, Y.; Morita, M.; Saito, S.; Kobayashi, Y.; Jun, B.; Bazan, N.G.; Xu, X.; Wang, Y. Stereoselective Synthesis of Maresin-Like Lipid Mediators. Synlett 2019, 30, 343-347.

117. Calder, P.C. Nutrition, immunity and COVID-19. BMJ Nutr. Prev. Health 2020, 3, 74-92. [CrossRef]

118. Alimohamadi, Y.; Sepandi, M.; Taghdir, M.; Hosamirudsari, H. Determine the most common clinical symptoms in COVID-19 patients: A systematic review and meta-analysis. J. Prev. Med. Hyg. 2020, 61, E304-E312.

119. Forni, G.; Mantovani, A.; Forni, G.; Mantovani, A.; Moretta, L.; Rappuoli, R.; Rezza, G.; Bagnasco, A.; Barsacchi, G.; Bussolati, G.; et al. COVID-19 vaccines: Where we stand and challenges ahead. Cell Death Differ. 2021, 28, 626-639. [CrossRef]

120. Simopoulos, A.P.; Serhan, C.N.; Bazinet, R.P. The need for precision nutrition, genetic variation and resolution in Covid-19 patients. Mol. Asp. Med. 2021, 77, 100943. [CrossRef]

121. Torrinhas, R.S.; Calder, P.C.; Lemos, G.O.; Waitzberg, D.L. Parenteral fish oil: An adjuvant pharmacotherapy for coronavirus disease 2019? Nutrition 2021, 81, 110900. [CrossRef] [PubMed]

122. Das, U.N. Can Bioactive Lipids Inactivate Coronavirus (COVID-19)? Arch. Med. Res. 2020, 51, 282-286. [CrossRef] [PubMed]

123. Rogero, M.M.; Leão, M.D.C.; Santana, T.M.; Pimentel, M.V.D.M.B. Potential benefits and risks of omega-3 fatty acids supplementation to patients with COVID-19. Free Radic. Biol. Med. J. 2020, 156, 190-199. [CrossRef] [PubMed]

124. Sorokin, A.V.; Karathanasis, S.K.; Yang, Z.H.; Freeman, L.; Kotani, K.; Remaley, A.T. COVID-19-Associated dyslipidemia: Implications for mechanism of impaired resolution and novel therapeutic approaches. FASEB J. 2020, 34, 9843-9853. [CrossRef] [PubMed]

125. Pham, T.L.; He, J.; Kakazu, A.H.; Calandria, J.; Do, K.V.; Nshimiyimana, R.; Lam, T.F.; Petasis, N.A.; Bazan HE, P.; Bazan, N.G. ELV-N32 and RvD6 isomer decrease pro-inflammatory cytokines, senescence programming, ACE2 and SARS-CoV-2-spike protein RBD binding in injured cornea. Sci. Rep. 2021, 11, 12787. [CrossRef] 